مجلة بحوث ودراسات الطفولة ـ كلية التربية للطفولة المبكرة - جامعة الفيوم ] ل العدد الخامس عثر

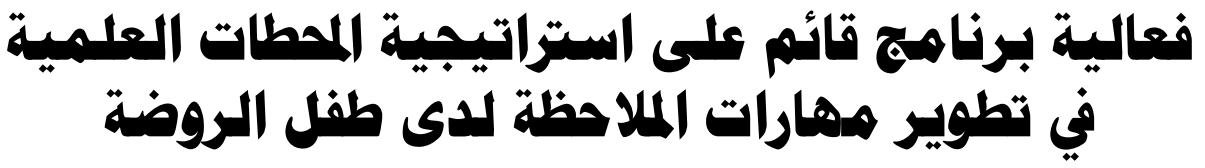

\author{
إعسداد \\ أ.م.د/سمر فتمي عبد المسنن

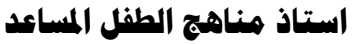 \\ وقائم بعمل رئيس قسم العلوم التربوية

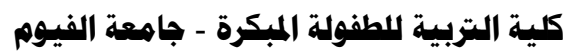

\title{
مـــــــــــــ
}

لم يعد الهدف في هذا العصر اكساب المتعلم المعلومات والمعارف وحدها، وإنما

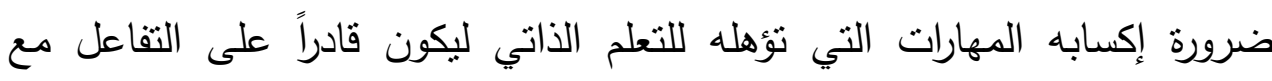
متغيرات العصر الغير مسبوقة ومنها الانفجار المعرفي والتطور السريع والمتلاحق في تكنولوجيا المعلومات.

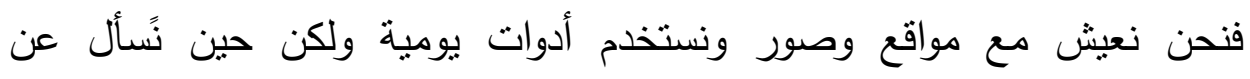

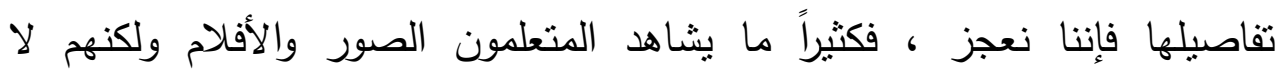
يلاحظونها، وحين يُطلب منا معلومات عن صورة عُرضت علينا نكتتف أننا لم

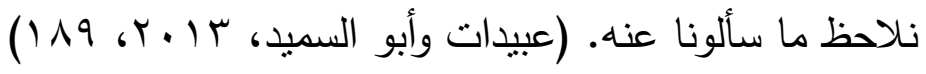
وكذلك طفل الروضـة قد بلاحظ شئ دون آخر في البيئة المحيطة بـه ليكون خبرة

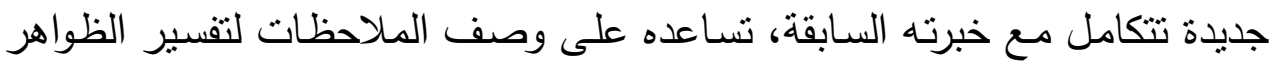

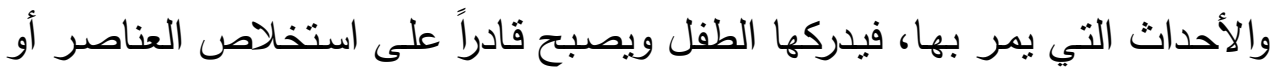
الصفات المشتركة للمفاهيم والحقائق التي يكتسبها، لذا فتطوير مهارات الملاحظـة

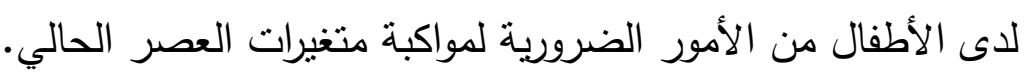

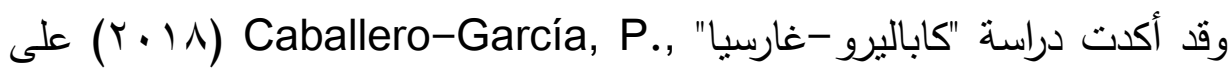
احتياج الأطفال في سن مبكرة جدًا إلى تطوير المهارات العلمية وخاصة مهارات الملاحظة باعتبارها كفاءة أساسية في الحياة والمدرسة في عالم دائم التغير . 
فتتمية مهارات الملاحظة لاى الأطفال تمكنهم من حل أي مشاكل نواجهرم في

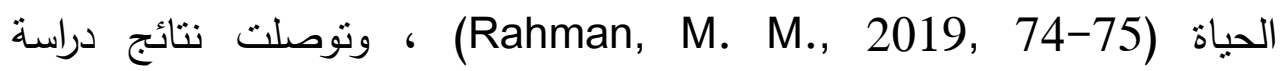

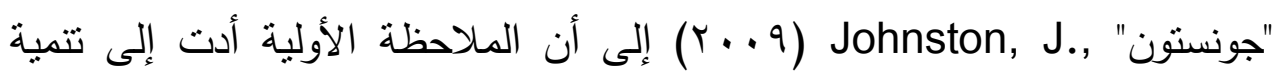
مهارات عملية علمية أخرى كالتصنيف والتتبؤ والافتراض والتفسير لدى الأطفال

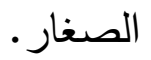

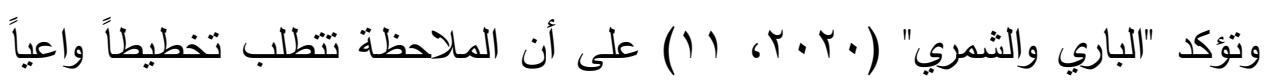
وتحتاج إلى تدريبات عملية لابد للمتعلمين أن يتدربوا عليها. فإنعدام التدريب على مهارات الملاحظة يعني حرمان الأطفال من التعلم الحقيقي للعلوم والذي يعتمد على استخدام كافة الحواس لممارسة عمليات العلم ومن ثم نوليد المعارف واكتثافها.

لذا استهدفت دراسة "فوزي وآخرون" Fauzi, F et al (19 • (Y) تتمية مهارات الملاحظة باعتبارها أحد مؤشرات معرفة مستوى تحقيق أهداف العملية التعليمية من خلال تأثير القصص المصورة مع النهج العلمي بالتعلم القائم على المشاريع.

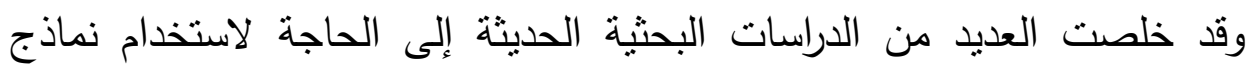

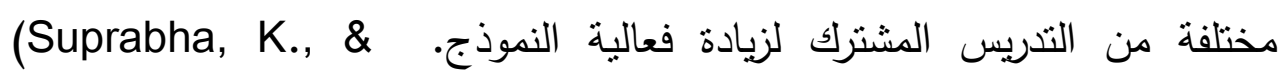

Subramonian, G., 2014, 24)

Aqel, M. S., \& Haboush, S. M., "ولقد أوصت دراسة "عقيل وحبوش بتوظيف استراتيجية محطات التعلم من قبل المعلمين. (Y) V V)

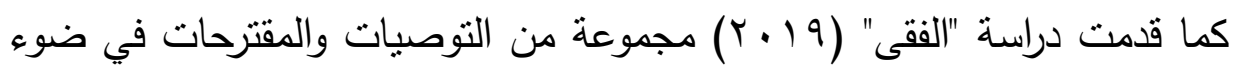
نتائج البحث التي توصلت إليها من أبرزها ضرورة توظيف استراتيجية المحطات التعليمية فى البرامج والأنشطة التعليمية المختلفة المقدمة لمرحلة الروضة.

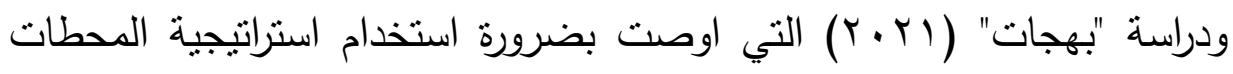
التعليمية في تتفيذ أنشطة الروضة.

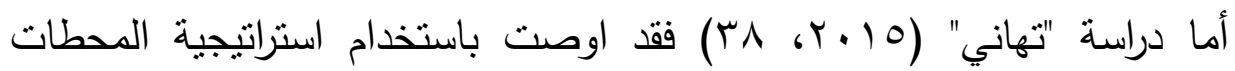
العلمية في تتمية بعض الاتجاهات والمهارات العلمية لاى أطفال الروضة. 
مجلة بحوث ودراسات الطفولة - كلية التربية للطفولة المبكرة - جامعة الفيوم) العدد الخامس عثر

لذا رأت الباحثة الإستفادة من إعداد وتطبيق برنامج قائم على استراتيجية المحطات العلمية لنطوير مهارات الملاحظة لدى طفل الروضة الرئة

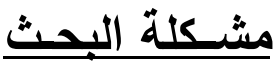

بدأ الإحساس بالمشكلة من خلال متابعة الباحثة للطالبات في روضات التدريب

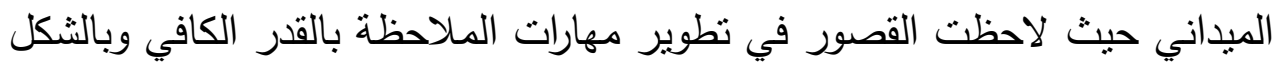

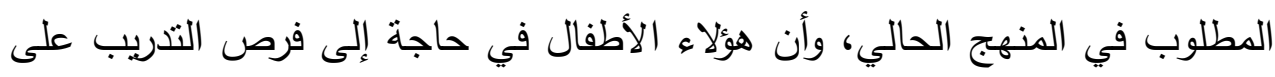

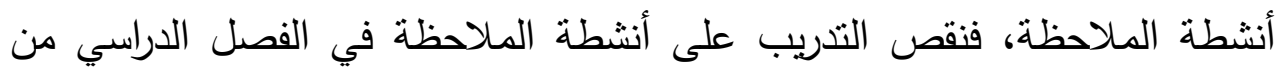

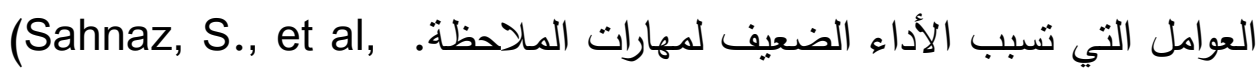
2018, 246)

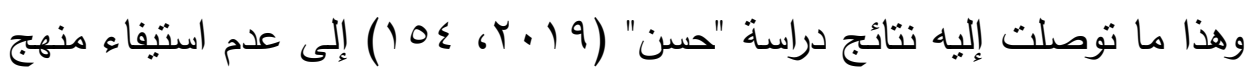

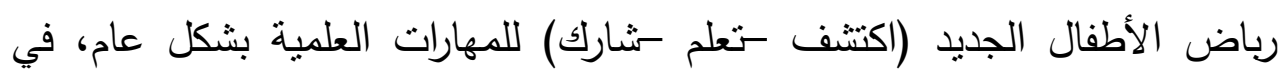

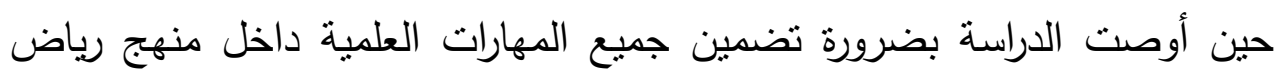

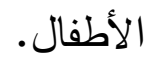

وتؤكد هذه المشكلة نتائج الدراسة الاسنطلاعية التي قامت بها الباحثة لمعرفة أرآء

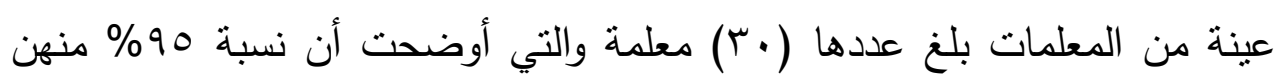

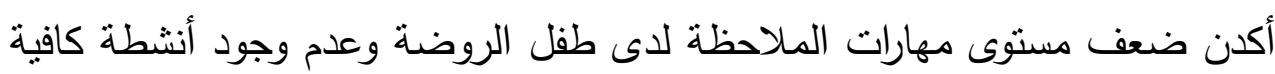
لتطويرها بشكل مباشر لاى الأطفال تلبي احتياجاتهم واهتماماتهر.

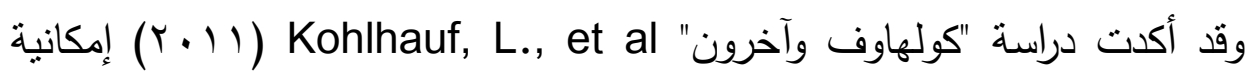

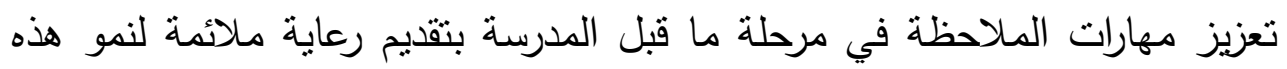

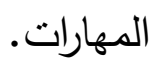

حيث يحتاج تطوير مهارات الملاحظة الجيدة إلى الدعم من خلال التدريس المركز

$$
\text { والمنظم.(Johnston, J., 2009, 3) }
$$

فيجب أن تؤدي وسائل التعلم المختارة إلى زيادة قدرة المتعلم على التأمل

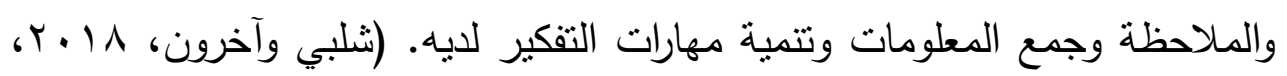


Aydogmus, M., \& Şentürk, "وقد أظهرت نتائج دراسة "ايدوجمس وسينترك

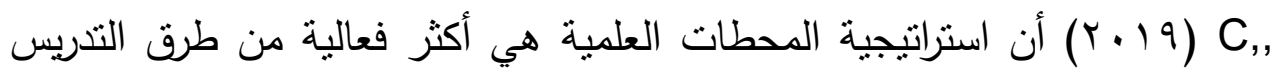
التقليدية في تتمية هذه المهارات، حيث تزود المتعلمين بفرص أفضل لممارسة وتطوير معارفهم ومهاراتهم المستهدفة (CARVAJAL, S., 2020, 13)، وهذا ما هال دعا الباحثة إلى إجراء البحث الحالي.

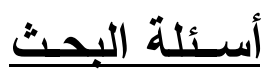
سعى البحث الحالي إلى الإجابة على الأسئلة التالية:

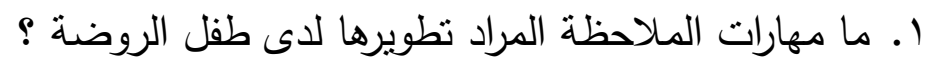
r. ما التصور المقترح لبرنامج قائم على استراتيجية المحطات العلمية لنطوير مهارات الملاحظة لاى طفل الروضة ؟ r. ما فعالية البرنامج القائم على استراتيجية المحطات العلمية في تطوير مهارات

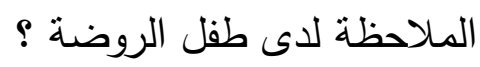

\section{أهــداف البحثث}

سعى البحث الحالي إلى تحقيق الأهداف التالية:

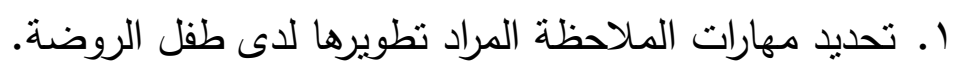

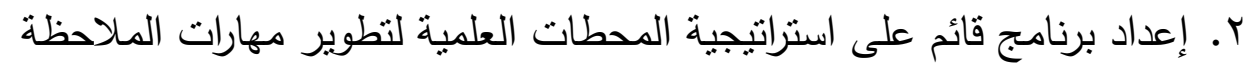

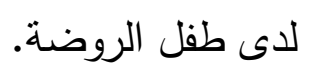

r. قياس فعالية البرنامج القائم على استراتيجية المحطات العلمية في تطوير مهارات الملاحظة لدى طفل الروضة.

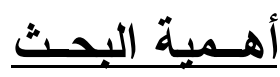
الأهمية النظرية: الهمبة البهاب بكتسب البحث أهميته من خلاه الآتي: ا. اهتم البحث الحالي بمرحلة رياض الأطفال حيث التعلم الحقيقي للعلوم والذي لإني

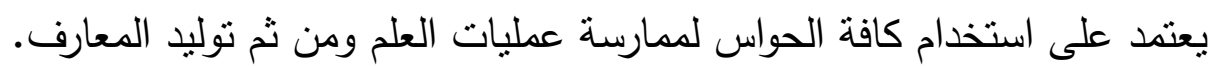


مجلة بحوث ودراسات الطفولة - كلية التربية للطفولة المبكرة - جامعة الفيوم لـ العدد الخامس عشر

r. اهتم البحث الحالي بتطوير مهارات الملاحظة باعتبارها أحد مؤشرات معرفة

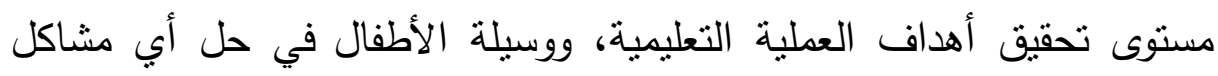

$$
\text { تواجهرم في الحياة. }
$$

r. ساعد البحث الحالي في تسليط الضوء على موضوع هام وهو توظيف استراتيجية المحطات العلمية التي تتيح للمتعلمين القيام بعملية تعلم ذاتية التوجيه.

\section{الأهمية التطبيقية:}

ا. قدم البحث الحالي مقياس مهارات الملاحظة المصور لطفل الروضة يمكن أن

يفيد الباحثين والمهتمين بتربية وتعليم الطفل.

r. تقديم عددًا من الأنشطة باستخدام استراتيجية المحطات العلمية لتطوير مهارات الملاحظة لدى طفل الروضة قد يستقيد منها مخططو المناهج والمعلمات. r. قدم البحث الحالي روية جديدة لكيفية توظيف استراتيجية المحطات العلمية في تعليم طفل الروضة المفاهيم المجردة وكذلك المفاهيم التي تحتاج إلى قدر كبير

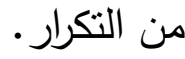

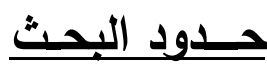

الحدود الزمنيـة: تم تطبيق أدوات البحث المبدانية في الفصل الدراسي الأول للعام

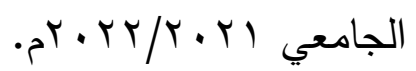
الحدود المكانية والبشرية: اقتصر البحث الحالي على عدد (ع 7) طفلاً وطفلة من

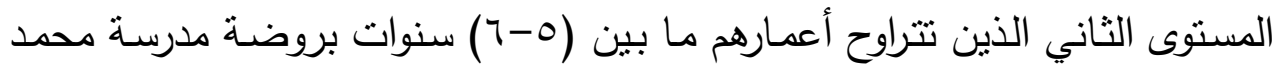

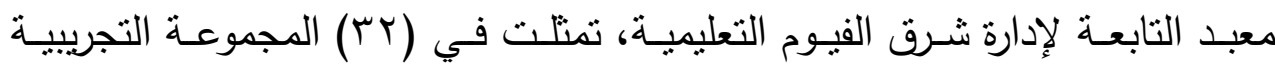
و و اrr) المجموعة الضابطة. الحدود الموضوعية: وقد اقتصر البحث الحالي على:

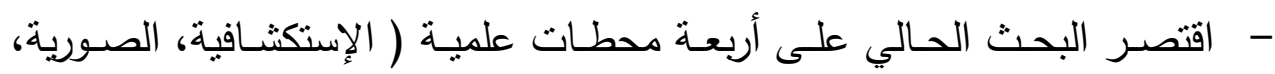
الإلكترونية، متحف الثمع ).

- اقتصر البحث الحالي على مهارات الملاحظة ( الوصف، التفسير ، الاستتناج ) بناءًا على استطلاع رأي المحكمين. 
مصــطات البحث

مهارات الملاحظة Observation skills : انتباه مقصود ومنظم نحو الظواهر أو الأحداث يمارسه المتعلم عن طريق الحواس بهدف اكتشاف الأسباب التي تجعل

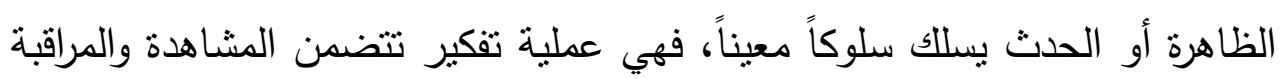
والإدراك وتُقترن عادة بوجود سبب قوي أو هدف يستدعي تركيز الانتباه ودقة

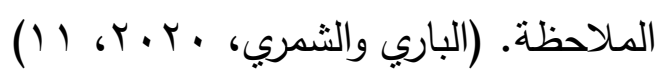

وتعرف الباحثة مهارات الملاحظة إجرائيًا في البحث الحالي بأنها : " قدرة الطفل

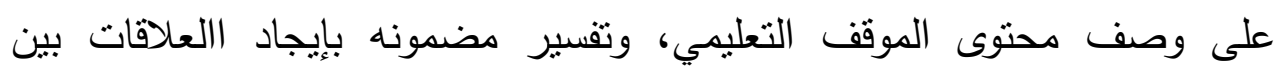
مكوناته، واستتناج ما يحمله من مفاهيم وقيم وأفكار جديدة وربطها بخبراته السابقة ". استراتيجية المحطات العلمية Learning Stations Strategy : إحدى منى استراتيجيات التدريس المشترك التي تتطلب تصميم ما لا يقل عن ثلاث محطات

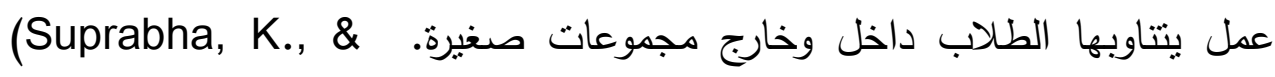
Subramonian, G., 2014, 22) وتعرف الباحثة استراتيجية المحطات العلمية إجرائيًا في البحث الحالي بأنها : "

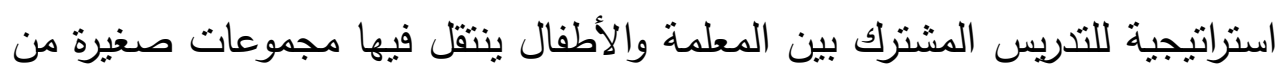

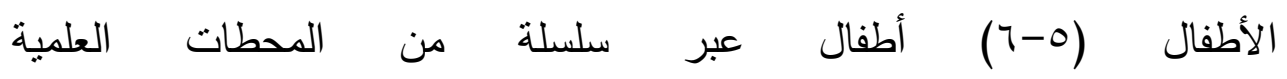
(الاستقصائية/الاستكثافية- الصورية- الالكترونية- متحف الثمع) بهدف تتمية مهارات الملاحظة لديهم ".

الإطسار النظري والدراسات السابقة Learning Stations المحسور الأول: اسـتراتيجية المحطـات العلميـة :Strategy مقدمة: استخدام المحطات في بيئة التعلم هي فكرة ترتبط ارتباطًا وثثقًا بنظرية مونتيسوري التعليمية بأهمية خلق بيئة تعليمية مناسبة تتيح للمتعلمين القيام بعملية تعلم ذاتية التوجيه، فهي إستراتيجية تتمحور حول المتعلم ويمكن تتفيذها في إطار مجموعة نعانه 
مجلة بحوث ودراسات الطفولة - كلية التربية للطفولة المبكرة - جامعة الفيوم لـ العدد الخامس عشر

منتوعة من المنهجيات في أي مجال وعلى مستويات مختلفة من التعليم. (CARVAJAL, S., 2020, 11)

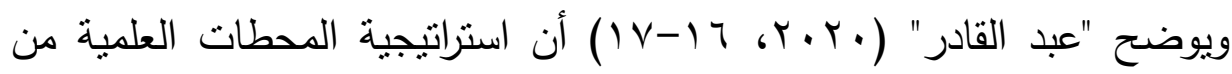
استراتيجيات التعلم الاجتماعي والتي يتم فيها تدريس الجانب النظري والعملي للمحتوى العلمي، حيث تقوم المعلمة بإعداد مجموعة من المحطات تختلف في لي

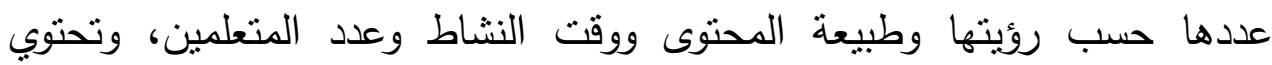
المحطات على أنشطة مختلفة منها ( صور - كتب- مجلات- تسجيلات- تجارب علمية- لعب أدوار - إنترنت .... إلخ )، ويقوم المتعلمون -بعد تقسيمه إلى ملى مجموعات- بالوقوف عند كل محطة وتتفيذ النشاط الخاص بكل محطة والإجابة على الأسئلة الموجودة بها خلال زمن محدد، وبعد الانتهاء من زيارة كل المحطات تقوم المعلمة بمناقشة المتعلمين فيما اكتسبوه من معلومات وخبرات واتجاهات أو قيم متضمنة في المحتوى العلمي. مفهوم المحطات العلمية:

يعرفها "جونز" " Jones, D. الأطفال في مجموعات عبر سلسلة من المحطات مصممة لتأدية الأنشطة بالتتاوب على المحطات المختلفة، مما يسمح للمعلمات بتميز التعليم بالموارد المحدودة لديهن من خلال دمج احتياجات الأطفال واهتماماتهم وأساليب التعلم، وتدعم هذه المحطات تعليم المفاهيم المجردة وكذلك المفاهيم التي تحتاج إلى قدر كبير من التكرار ، ويمكن للمحطات أن تغطي مفهوم واحد أو العديد من المفاهيم ".

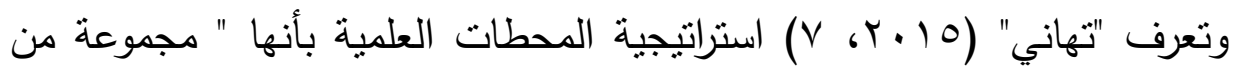
الإجراءات التي تعتمد على تقسيم الأطفال إلى مجموعات لممارسة مجموعة من

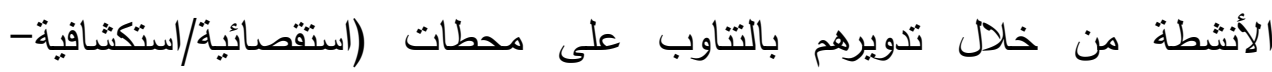

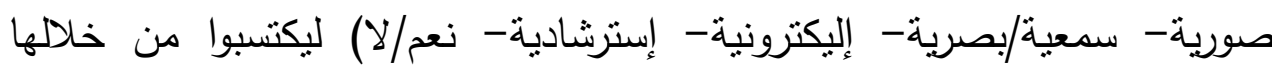
بعض المفاهيم العلمية وعمليات العلم ". ويمكن تعريفها أيضاً بأنها " استراتيجية تضم مجموعة أنشطة علمية يتم ممارستها داخل الصف أو المختبر من قبل المتعلمين أنفسهم، وتكون منوعة منها: الاستكثافية 
البسيطة أو القرائية أو الاستقصائية أو الإكترونية وغيرها "، ويمكن وصفها بأنها " مجموعة من الطاولات داخل غرفة الصف أو المختبر وكل طاولة تعد محطة، لها

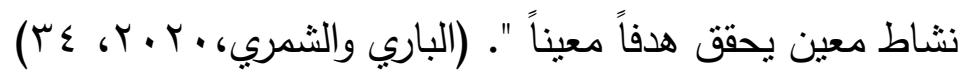
فوائد التعلم بالمحطات العلمية: من فوائد التعلم بالمحطات العلمية ما يلي:

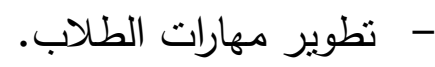

- منح المرونة للمعلمين في تغيير أنماط التفاعل: (المعلم والطالب، الطالب والطالب، الطلاب والمواد).

- - استخدام الطلاب المواد المحسوسة قبل الانتقال للمفاهيم المجردة. - تقليل شعور الطلاب منخفضي التحصيل الأكاديمي بالإحباط والمشكلات السلوكية عبر تتقلهم بالمحطات.

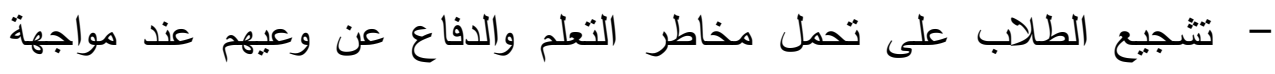
المحتوى الصعب، وطرح الأسئة التي تدعم تطوير عمليات التفكير ما وراء المعرفي.(Suprabha, K., \& Subramonian, G., 2014, 24) - تُشتخدم المحطات بشكل أساسي لمراجعة المحتوى العلمي. - تزود الطلاب بفرص أفضل لممارسة وتطوير معارفهم ومهاراتهم المستهدفة. (CARVAJAL, S., 2020, 13)

وإضافة إلى الفوائد السابقة فقد أثثتت استراتيجية المحطات العلمية فاعليتها في

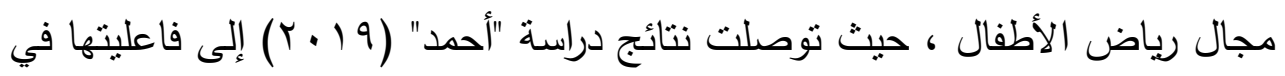
تنمية بعض مفاهيم الثقافة الصحية لدى الطفل، كما أثنارت نتائج دراسة "الفقى"

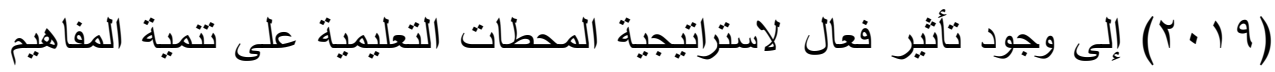

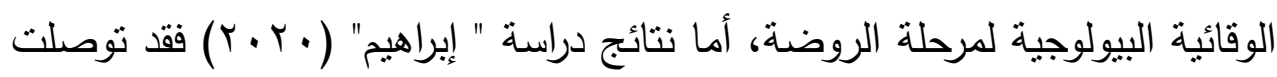
إلى وجود أثز كبير لإستخدام المحطات التعليمية التفاعلية في تتمية المفاهيم

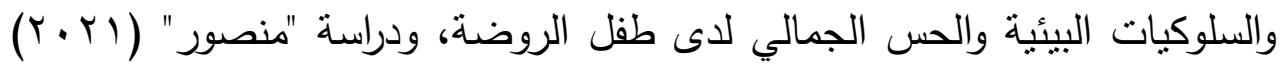
التي توصلت نتائجها إلى وجود فاعلية البرنامج القائم على المحطات التعليمية في الحد من الآثار السلبية لتعرض طفل الروضة لمفردات العالم الافتراضي، ودراسة 
مجلة بحوث ودراسات الطفولة - كلية التربية للطفولة المبكرة - جامعة الفيوم لـ العدد الخامس عشر

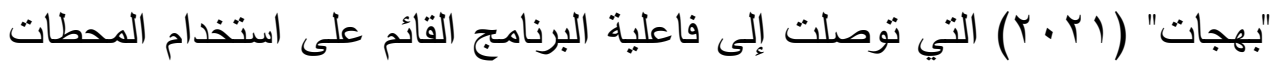
التعليمية في تتمية مفاهيم الفضاء وعلوم الأرض لدى الطفل. طرق تنفيذ إستراتيجية المحطات العلمية: يتم اختيار الطريقة المناسبة على حسب طبيعة المحتوى وخصائص المتعلمين

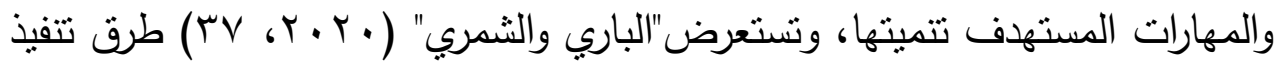

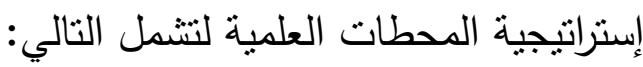
ا. التجوال على كل المحطات : يتم الاعتماد عليها عندما تحتاج المحطات إلى وقت قصير، وفيها يحدد المعلم عدد المحطات، ويقسم طلاب الصف إلى إلى مجموعات تساوي عدد المحطات، كل مجموعة تضم (ع-7) طلاب، وبعد مرور (0) دقائق يعلن المعلم انتهاء الوقت ويطلب من المجموعات الانتقال إلى هـ

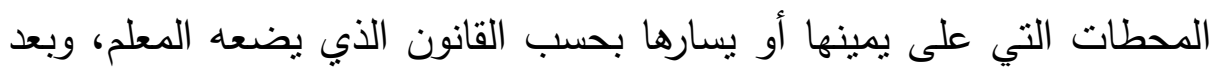

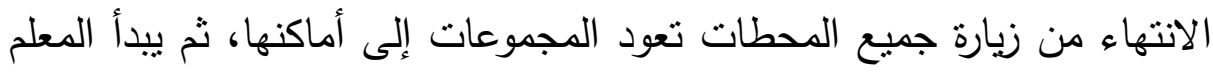
بمناقثة أوراق العمل ونتائج المجموعات في كل محطة، ثم يغلق المعلم النشاط. r. التجوال على نصف المحطات : ويتم الاعتماد على تلك الطريقة عندما تحتاج

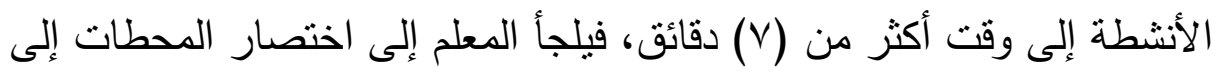

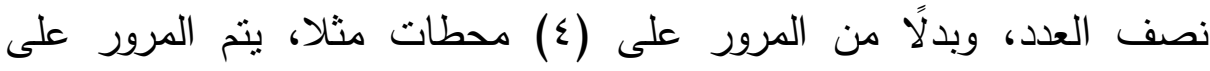
محطنين فحسب، وهنا يتم تصميم (ع) محطات كل اثثتين منتابهتين، ويستغرق المكوث عند كل محطة نحو (10) دقيقة. r. التعلم المجزأ : وتعتمد تلك الطريقة عندما يراد اختصار الوقت، وفيها يتوزع أعضاء المجموعة الواحدة بين المحطات المختلفة، إذ يزور كل عضو من ينداد

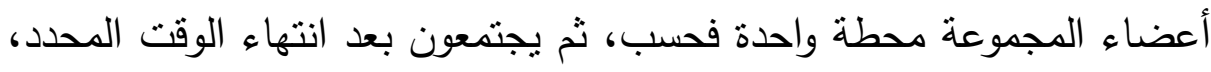
وبدلي كل طالب بما قام به وشاهده في المحطة التي زارها، وبذلك يتبادلون الخبرات.

وفي البحث الحالي تم الإعتماد على الطريقة الثانية "التجوال على نصف

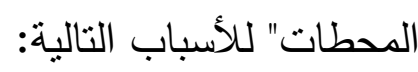


تلائم خصائص نمو أطفال الروضة حيث يحتاجون إلى وقت طويل داخل المحطات، وإلى تواجد المعلمة معهم بعض الوقت.

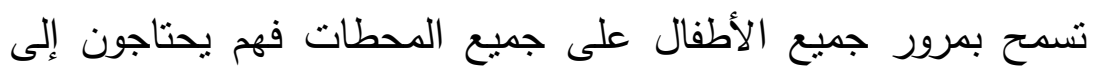
المرور بالخبرة بأنفسهم. توفر فرص تبادل الخبرات والحوار بين الأطفال. توفر فرص التعلم الذاتي والتعلم النشط. تلائم الهذف من البحث الحالي وهو تتمية مهارات الملاحظة لدى الدى لون الأطفال حيث تحتاج إلى طرح الأسئلة عليهم من قبل المعلمة لإستئتارة تفكيرهم.

عوامل نجاح العمل داخل المحطات العلمية:

من أجل نجاح تتفيذ استراتيجية المحطات العلمية من الضروري مراعاة ما يلي: تخطيط المحطات وتوقيتها. (CARVAJAL, S., تحديد أهداف واضحة وقابلة للقياس لكل محطة. 2020, 14)

تتاوب المحطات كنهج لتخصيص تعلم الطلاب. Fulbeck, E., et al, 2020, 2) إجراء قدر كبير من التخطيط المسبق قبل التنفيذ الفعلي في الفصول الدراسية يشمل الجوانب التالية: - تحديد فلسفة وأهداف مشتركة وقواعد أساسية. - - جدولة الاجتماعات وتخطيط التعليمات اللاحقة. - - تحديد الأدوار والمسؤوليات. - - تحديد واختيار مجموعة منتوعة من الأشكال التعليمية. - - إعداد خطة عملية للتعامل مع مشاكل الطلاب. (Suprabha, K., \& Subramonian, G., التخطيط لعملية التقويم 2014, 23) 
مجلة بحوث ودراسات الطفولة - كلية التربية للطفولة المبكرة - جامعة الفيوم لـ العدد الخامس عشر

أنواع المحطاث العلمية :

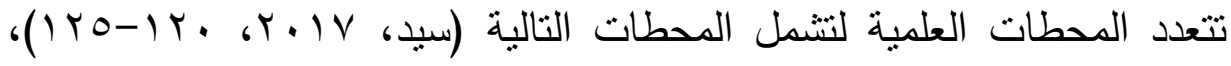

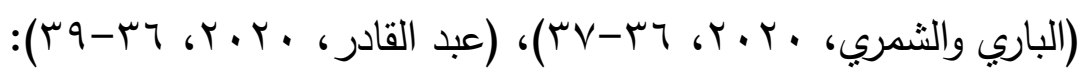

1. المحطة الاستقصائية/الاستكشافية: تختص بالأنشطة المختبرية (المعملية) التي تتطلب إجراء تجربة معينة ووضع الأدوات والمواد التي يحتاج إليها المتعلمين عند مرورهم بهذه المحطة، وتهدف إلى اكتشاف المتعلمين ما هو محدد لهم أو لوديه التوصل إلى نتيجة معينة. r. المحطة القرائية: تعتمد على مادة قرائية يتم تهيئتها من المعلم بهدف تكوين

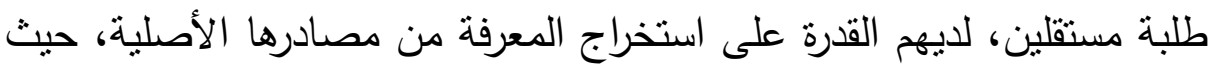
تجهز هذه المحطة بمادة علمية مطبوعة أو من الإنترنت أو من كتاب، والإجابة ملية على عدد من الأسئلة المصاحبة.

r. المحطة الاستثارية: وتكون مخصصة للخبراء، فيقف المعلم خلف تلك المحطة أو أحد الطلبة المتفوقين، وعندما يصل الطلبة إلى الخبير يوجهون إليه أسئلة تتعلق بموضوع الدرس، فيتم توسيع مداركهم حول الجوانب المختلفة للمادة العلمية التي لم يستطيعوا فهمها. ـ. المحطة الصورية: تتميز بوجود عدد من الصور أو الرسومات، يتفحصها الطلبة ويجييون عن الأسئلة المتعلقة بها، وهنا قد يستعين المعلم بموسوعة علمية، أو ملصق جاهز، أو حكاية مصورة من إحدى المجلات التي تختص التص بتحويل الموضوعات العلمية إلى قصص مصورة، فتساعد التلاميذ على تقريب إنى المفاهيم العلمية والخبرات المحسوسة إلى أذهانهم. هـ المحطة الإكترونية: تحتاج هذه المحطة إلى جهاز حاسوب، إذ يطلب من التلاميذ مشاهدة عرض تقديمي على البوربوينت Power Point أو فيديو متصل بموضوع الدرس، أو يقومون بالبحث في الإنترنت، ثم الإجابة عن الأسئلة المصاحبة لهذه المادة العلمية. 7. محطة متحف الشمع: ترتبط بشخصيات علمية لها علاقة بموضوع الدرس، حيث بطلب من أحد التلاميذ سواء داخل الفصل أو خارجه تقصيطه بته شخصية 
علمية منل أحد العلماء، ومن الأفضل أن تكون أمامه نماذج من كتبه أو الأجهزة التي قام باختراعه أو صور تحكي أهم إنجازاته، ويتحدث عن مادة الأن علمية مرتبطة بموضوع الدرس نفسه.

V. محطة النعم/لا: تعد من المحطات الممتعة والمثيرة لتفكير التلاميذ، فيحضر لترن المعلم تجربة بسيطة، أو يدرب تلميذًا على ذلك، وتقوم المجموعة التي تصل لتصل

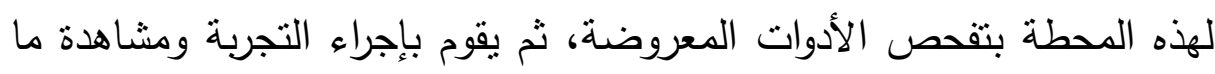
يحدث، وللحصول على تفسير لما حدث تبدأ المجموعة بطرح عدد من الأسئلة على المعلم أو الطالب المكلف بالوقوف عند تلاك المحطة، شرط أن تكون إجاباتها بكلمة نعم أو لا حتى يتم التوصل إلى الإجابة.

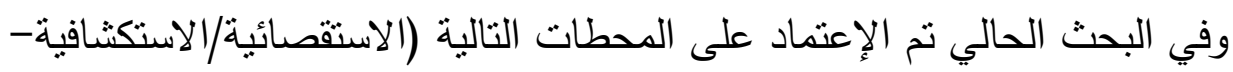
الصورية- الالكترونية- متحف الثمع) للأسباب التالية: 1. عدم ملائمة بعض المحطات لخصائص نمو طفل الروضة مثل المحطة لابهة القرائية. r. دمج بعض المحطات لتحقيق الأهداف المحددة مثل المحطة الاسنشارية

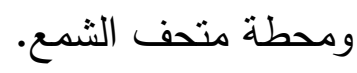
r. إمكانية تحقيق أهداف محطة النعم/لا في المحطة الاستقصائية/الاستكثافية

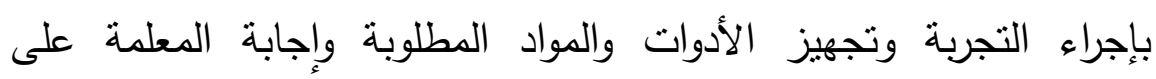

$$
\text { تساؤلات الأطفال. }
$$

ع. تعديل مواد ووسائل بعض المحطات لتلائم طفل الروضة مثل محطة متحف الثمع باستبدال الثخصيات العلمية بشخصيات مجسمة مألوفة للطفل منل

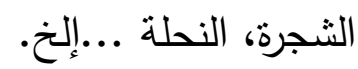
خطوات توظيف استراتيجية المحطات العلمية لتطوير مهارات الملاحظة لاى طقل

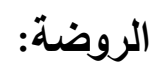
لتوظيف استراتيجية المحطات العلمية في تطوير مهارات الملاحظة لاى طفل الروضة في البحث الحالي تم إتباع الخطوات التالية: ا ـ تحديد الأهداف الإجرائية المراد تحقيقها داخل المحطات العلمية. 
مجلة بحوث ودراسات الطفولة - كلية التربية للطفولة المبكرة - جامعة الفيوم لـ العدد الخامس عشر

r . تحديد المفاهيم العلمية والمحتوى العلمي المراد تدريسه لتطوير مهارات الملاحظة (الوصف، التفسير ، الاستتاج) لدى طفل الروضة. r. اختيار نوعية الأنشطة التي يمكن تتفيذها داخل المحطات، ومراعاة تتاول المفهوم الواحد بأكثر من زاوية، وتحديد المحطات التي ستتطلب نواجد الباحثة أو

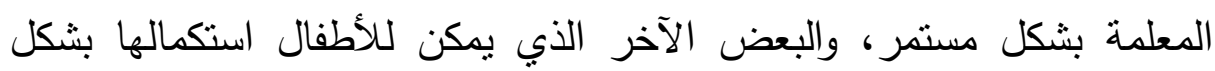

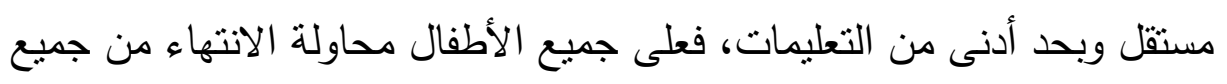
المحطات في نفس الوقت. ـ. مراعاة التذرج في مستوى الأنشطة داخل المحطات العلمية بحيث تتاسب قدرات الأطفال واهتماماتهم وأنماط تعلمهم. ه. تزوبد كل محطة من المحطات العلمية الأربعة (الاستقصائية/الاستكثافية-

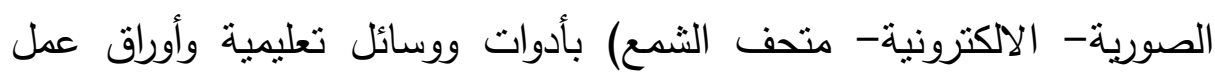
لممارسة النشاط المطلوب منل ( أثنياء ونماذج حقيقية، حاسب آلي، فيديوهات تعليمية، أفلام تعليمية، عرض بور بوينت، كتب مصورة ، بطاقات مصورة،

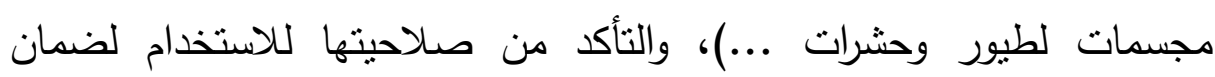
الاستفادة منها بشكل جيد.

7. تشكيل مجموعات التعلم التعاوني وعددها أربع مجموعات غير متجانسة، كل مجموعة تتكون من ثماني أطفال تقريباً، يتم توزيعهم على المحطات الأربعة.

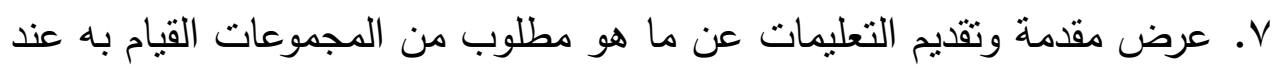
تجوالها على المحطات العلمية. ^. وضع أوراق عمل كل محطة في المكان المخصص لهاه لها. 9. تخصيص الزمن المخصص لكل محطة علمية.

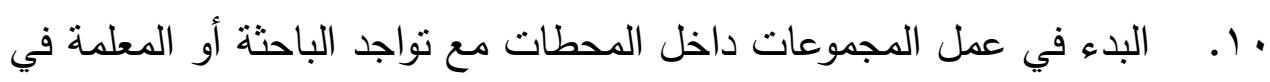
المحطات التي تتطلب تواجدها بشكل مستمر، وملاحظة الأطفال وتقديم المساعدة والدعم لهم وقت الحاجة في المحطات التي تعمل بشكل مستقل وتوزيع

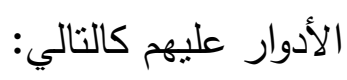


- - القائد: وعليه التأكد من أن جميع الأطفال يثاركون في أداء المهام، مراقبة

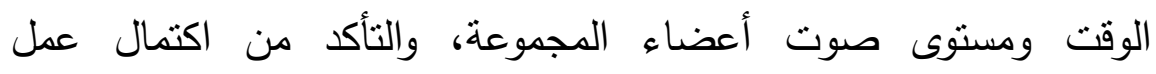
المجموعات، والإشراف على تتظيف المحطات قبل الدوران إلى المحطة التالية. - المسجل: تتمثل مسئولياته في التأكد من إكمال جميع أوراق العمل أثناء قيام

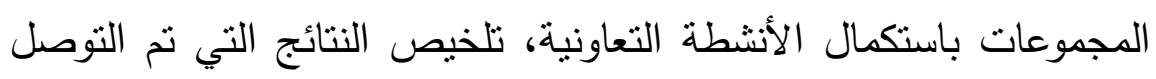

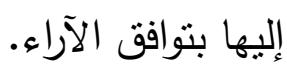
- المورد: وتتحصر مسئولياته في الحصول على الإمدادات للمجموعة، إعادة جميع الإمدادات عند الانتهاء من عملهم داخل المحطة. - المعلوماتي: وتتحدد مسئولياته في الحصول على المعلومات للفريق، الحصول على الأوراق، سؤال المعلم عند الحاجة إليه. 11. إعلان البدء بتتفيذ أوراق عمل المحطات، ويتم احتساب الوقت على ألى ألا يتجاوز أكثر من (· (1) دقائق في كل محطة.

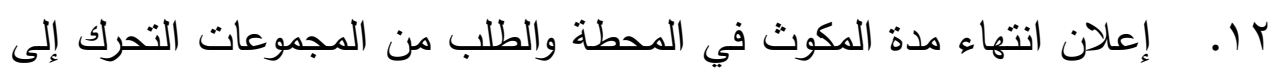
المحطة التالية بحسب اتجاه حركة عقرب الساعة. با. . عودة المجموعات إلى أماكنها بعد الانتهاء من التجوال على على كل المحطات،

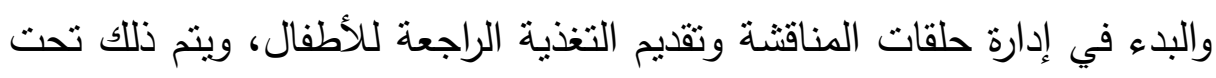

$$
\text { إثراف الباحثة أو المعلمة. }
$$

ع ا. تسلم أوراق الإجابة من المجموعات والقيام بتصحيحها وإعادتها إليهه في المرة اللاحقة. 
مجلة بحوث ودراسات الطفولة - كلية التربية للطفولة المبكرة - جامعة الفيوم لـ العدد الخامس عشر

المحور الثاني: مهارات الملاحظة Observation skills

مقدمة:

مهارات الملاحظة من أهم مهارات العلم الأساسية، فهي تعتبر من مهارات التعلم مدى الحياة التي تُستخدم في حل ومعالجة مشكلات الحياة اليومية، ويحتاجها الأطفال في مرحلة الطفولة المبكرة فهي تتماشى مع منطلبات نموهم المعرفي وتحصيلهم العلمي في هذه المرحلة.

وتطور النمو المعرفي يهدف إلى تمكين الطفل من استكثاف العالم المحيط به

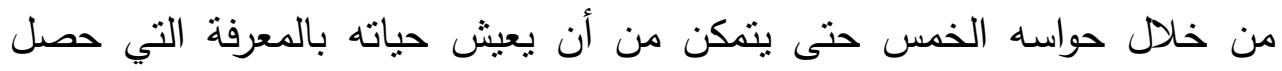

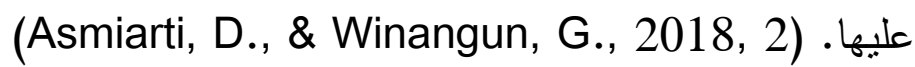

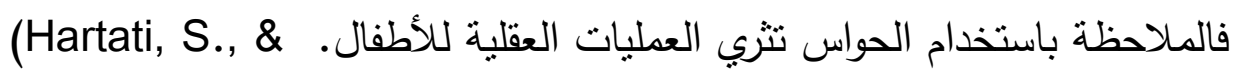

Novrika, G. V,, 2018, 31)

حيث تُستخدم في مهارات الملاحظة حاسة أو أكثر من الحواس الخمس لجمع المعلومات عن الأثياء أو الأحداث أو الظواهر بتسميتها ووصف العلاقات بينها بطريقة شفوية أو باستخدام الصور أو الرسم وذلك لتيسير الفهم على المتعلم والتوصل إلى مجموعة من الأفكار أو المفاهيم أو القيم المبنية على الملاحظات والمتأثرة بالخبرة السابقة.

فمهارات الملاحظة من المهارات البصرية الأولية والتي يجب أن يسيطر علئها

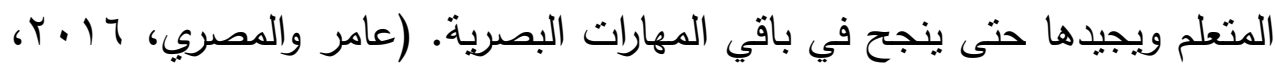

\section{مفهوم مهارات الملاحظة:}

يقصد بالماحظة استخدام الحواس في التعرف على الأشياء: الأشكال والألوان والأحجام والأطوال والحركة، كما نلاحظ الكل والأجزاء والعلاقات بينها، من المهح ملاحظة الأثياء والأحداث والمواقف بربطها بوظائفها، حيث تعتبر الملاحظة أداة قوية للحصول على المعلومات خاصة إذا كانت حواسنا سليمة وملاحظاتنا مقصودة.

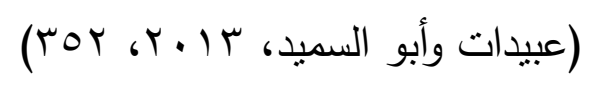


فالملاحظة هي "القدرة على وصف شئ ما باستخدام الحواس الخمس البصر والسمع والثم واللمس والتذوق، وهي مهارة أساسية أولية ثُنْى وتعتمد عليها باقي

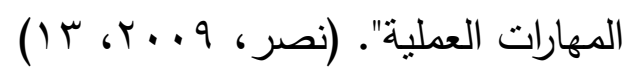

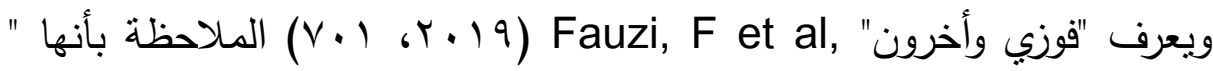
القدرة على التعرف على الأشياء وتذكرها بالتقصيل للمساعدة في الإجابة عن المشكلات العلمية وتوفير طريقة لتلقي المعلومات ". وتتير مهارة الملاحظة إلى جمع البيانات وفهم وتفسير معنى المعلومات باستخدام جميع الحواس. (Rahman, M. M., 2019, 71) أنواع مهارات الملاحظة:

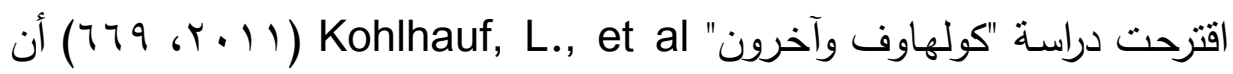

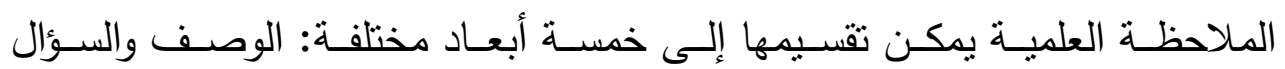
والافتراض والاختبار والتقسير -

تم تضـمين مهارات الملاحظـة: مهارات اسـتخدام العديـد مـن الحـواس، وتحديـ

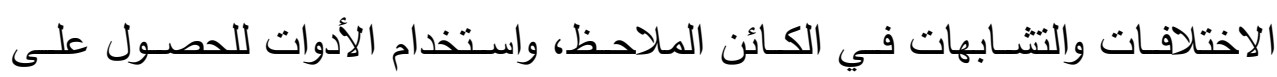
البيانات، والبحث عن البيانات ذات الصلة. (Sahnaz, S., et al, 2018, 246) أمـا دراسـة "يوروميزوغلو وأوزتاس سين"

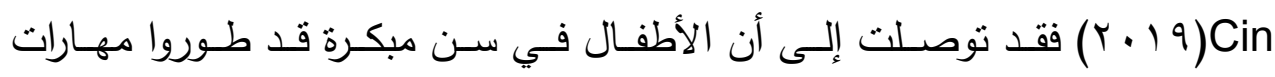

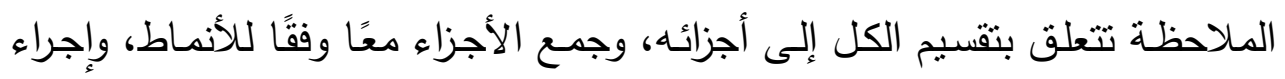
ملاحظات تفصيلية، وجمع بيانات منهجية، وقد نجحوا في تتفيذ هذه المهارات خارج الفصل الدراسي والمدرسة. وفي دراسـة "فوزي وأخرون" Fauzi, F et al, الملاحظة على الوصف والتفكير العلمي والتفسير • Fauzi, F et al, 2019, 705) وفي البحث الحالي وبناءاً على آراء السادة المحكمين تم التوصل إلى مهارات

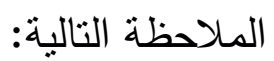


مجلة بحوث ودراسات الطفولة - كلية التربية للطفولة المبكرة - جامعة الفيوم) العدد الخامس عثر

1. مهارة الوصف: وهي قدرة الطفل على تسمية عناصر أو مكونات الموقف

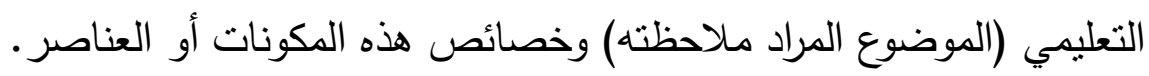

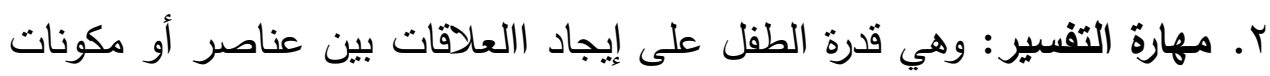
الموقف التعليمي بالمقارنة بينها وتحديد أوجه الثبه والاختلاف الثلات وجمع البيانات

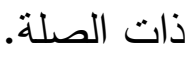

r. مهارة الاستتناج: وهي قدرة الطفل على استخلاص مفاهيم وقيم وأفكار جديدة

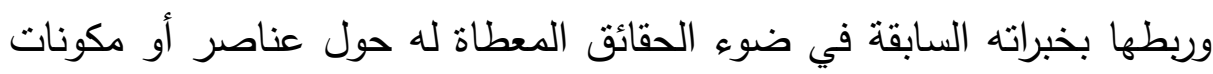
الموقف التعليمي.

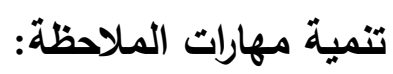

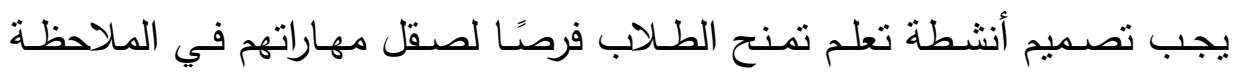

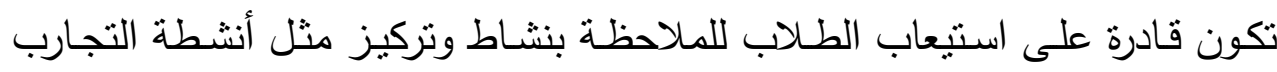

والمناقثنات. (Sahnaz, S., et al, 2018, 246-247)

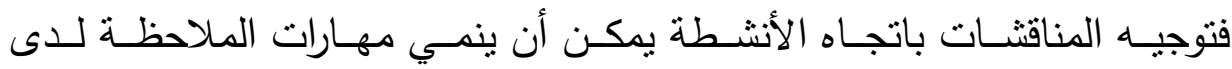

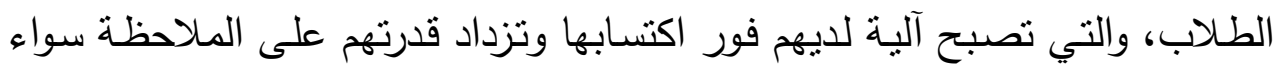

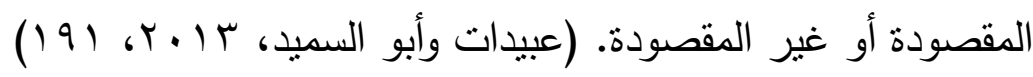

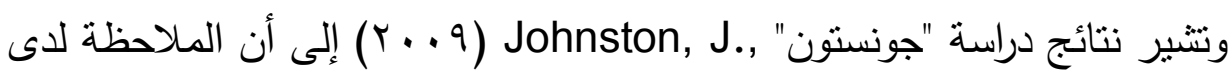

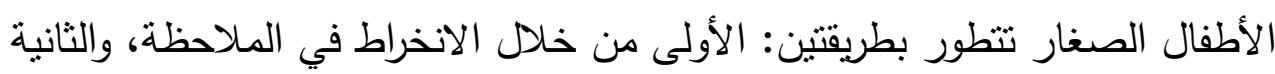
من خلال تقسير الملاحظة بالاستفادة من المعرفة والخبرات السابقة.

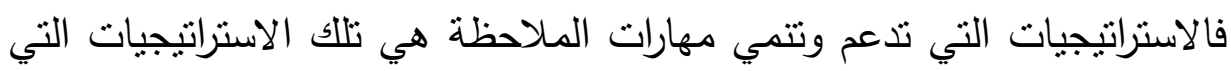

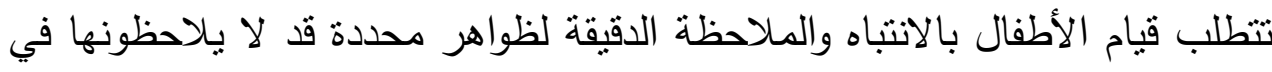

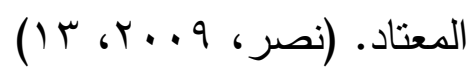

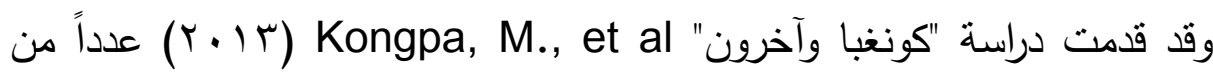
الأنشطة بوحدة الأثجار سمحت للطلاب بالملاحظة وجمع البيانات والرسم والتلوين والتواصل.

أما دراسة "يوروميزوغلو وأوزتاس سين" بurumezoglu \& Oztas

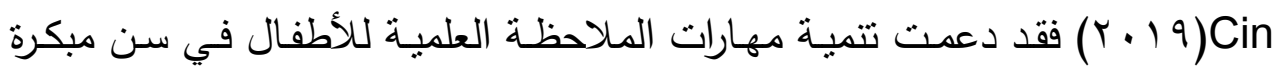


باستخدام نمط تم اختياره من الطبيعة المحيطة (البرسيم الثـائك) وهو نبات فريد من نوعه في منطقة البحر الأبيض المتوسط، حيث تم تصميم نشـاط ملاحظـة بسيط ومبتكر وحقيقي باستخدام هذا النبات يهدف إلى تحويل مهارات الملاحظة التلقائية للأطفال إلى مهارات ملاحظة علمية.

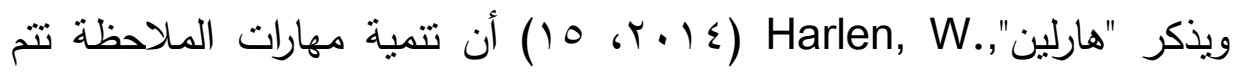
باستخدام مصادر المعلومات وجمع الأدلة من خلال عدة إجراءات يمكن للمعلمين اتخاذها كما يلي:

ا ـ توفير فرص غير رسمية لاستخدام الحواس لجمع المعلومات عن طريق:

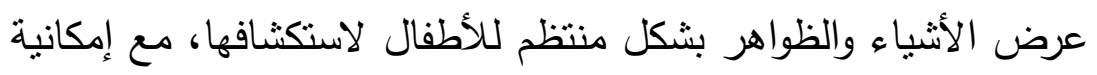
الوصول إلى كتب المعلومات أو الأقراص المضغوطة ذاء ذات الصلة في مكان قريب.

مجموعة من الأشياء المتعلقة بموضوع جديد قبل أسبوعين أو ثلاثة أسابيع من بدء إثارة الاهتمام. تخصيص وقت للملاحظة. r. تشجيع الملاحظة من خلا "دعوات الملاحظة" وهي البطاقات الموضوعة

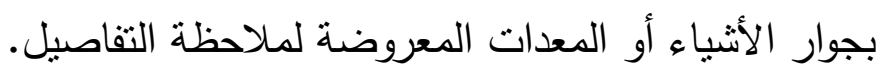

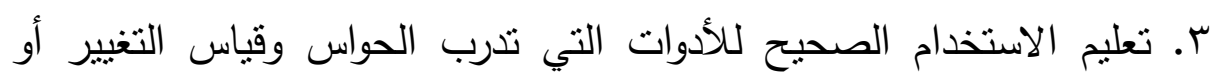
الاختلافات.

ع. تعليم تقنيات استخدام مصادر المعلومات منل الكتب المرجعية والإنترنت. ه. إعداد المواقف حيث يتم تبادل الملاحظات. 7. نتظيم الزيارات لملاحظة الأحداث والأشياء خارج الفصول الدراسية، وقد تم الاعتماد على معظم هذه الإجراءات في برنامج البحث الحالي.

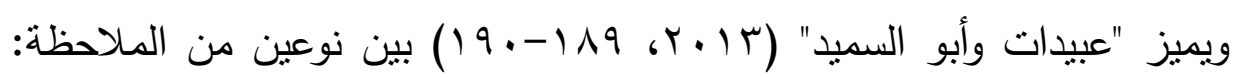
العابرة والتي يمكن أن تزود المتعلمين ببعض المعلومات بشكل عرضي، والمقيدي المصودة والتي توجه اهتمامهم لثيء أو حدث بهدف الحصول على معلومات معينة ويمكن 
مجلة بحوث ودراسات الطفولة - كلية التربية للطفولة المبكرة - جامعة الفيوم لـ العدد الخامس عشر

التدريب عليها مثلاً من خلال عرض فيلماً تعليمياً عن الإسكيمو بإتباع المعلم للخطوات التالية: ا ـ يعد الفيلم ويجهزه للعرض.

r. يناقش المتعلمين في موضوع الفيلم، ويوجه انتباههم إلى معالم رئيسة.

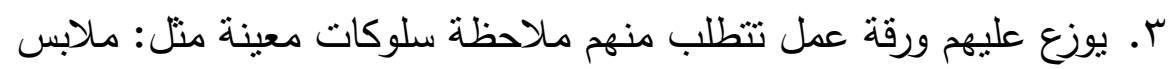

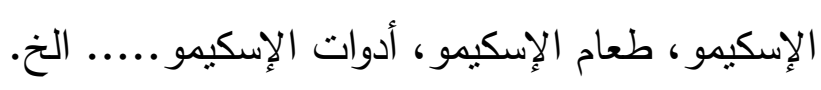

ـ. يناقش المتعلمين فيما لاحظوه، وقد نم اتباع هذه الخطوات في برنامج البحث الإنى الحالي وخاصة في المحطة الالكترونية.

فوضرض البحثي

ا. يوجد فرق دال إحصائًَا بين متوسطي درجات أطفال المجموعة التجريبية

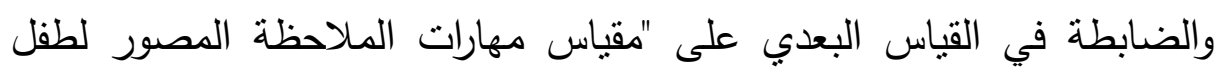
الروضة " لصالح المجموعة التجريبية. r. يوجد فرق دال إحصائيًا بين متوسطي درجات أطفال المجموعة التجريبية في

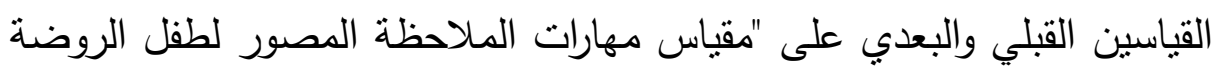

$$
\text { " لصالح القياس البعدي. }
$$

r. يوجد فرق دال إحصائيًا بين منوسطي درجات أطفال المجموعة التجريبية في البعاي

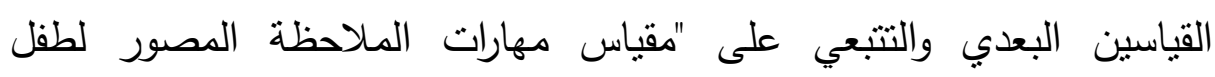
الروضة " لصالح القياس النتبعي.

\section{خطوات وإجراءات البحث المبداتية البهية}

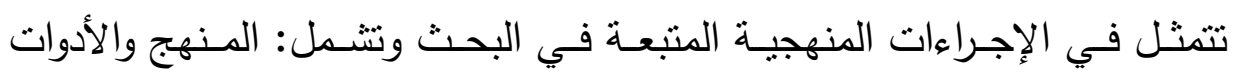
المستخدمة والتجربة الميدانية وكذلك الأساليب الإحصائية لمعالجة البيانات.

\section{منهمج البحث}

اتبع البحث الحالي المنهج شبه التجريبي ذو المجموعتين الضـابطة والتجريبية،

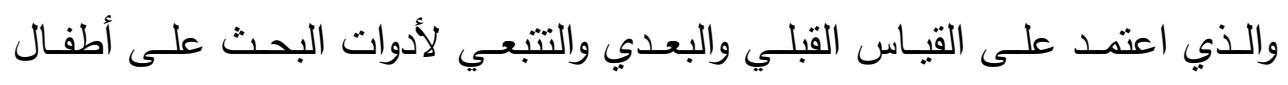

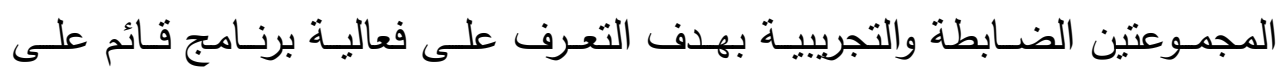


استراتيجية المحطات العلمية (كمتغير مستقل) ومدى مساهمته في تطوير مهارات الملاحظة لدى طفل الروضة (كمتغير تابع). مجتمع وعينة البحث:

يتمثنل مجتهـع البحـث الحسالي في جميع مؤسسـات ريـاض الأطفال بمحافظـة

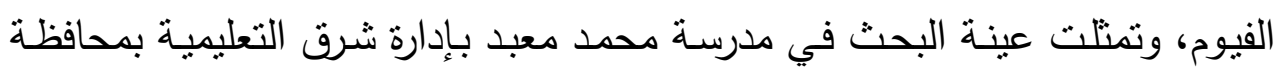

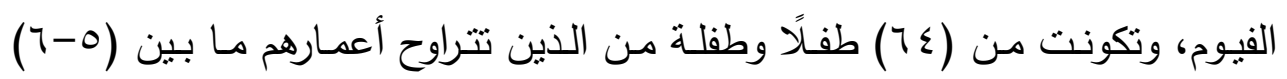

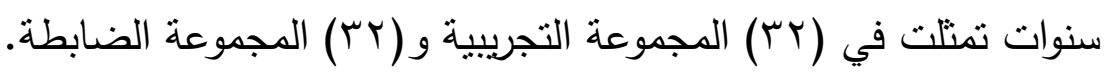
التحقق من تكافؤ المجموعتين التجريبية والضابطة قبلياً:

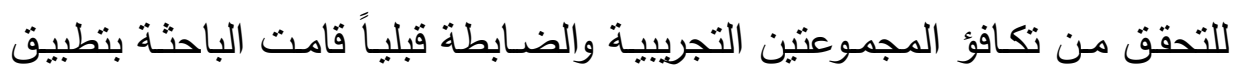

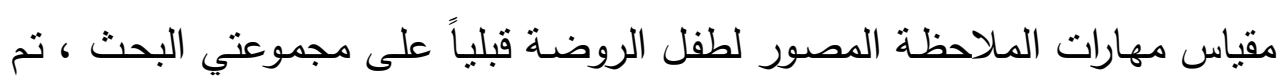
استخدام اختبار "ت" للعينات البارمترية الغير مرتبطة من خلال البرنامج الاحصائي SPSS ، وجاءت النتائج كالتالي كما يتضح من جدول ( ) : (1)

\section{جدول (1)}

الفرق بين متوسطي درجات أطفال المجموعتين التجريبية والضابطة في التطبيق القبلي لمقياس

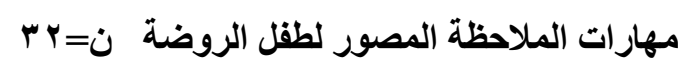

\begin{tabular}{|c|c|c|c|c|c|c|c|c|}
\hline \multirow{2}{*}{ مستوى } & \multirow{2}{*}{$\begin{array}{c}\text { ق } \text { المحدة } \\
\text { T }\end{array}$} & \multirow{2}{*}{ اللانحراف } & \multirow{2}{*}{ متوسط } & \multicolumn{2}{|c|}{ المجموعة الضابطة } & \multicolumn{2}{|c|}{ المجموعة التجريبية } & \multirow{2}{*}{ أبعاد } \\
\hline & & & & الانحراف & الحسابي & الاتحراف & المستوسط & \\
\hline غير & $1.1 \varepsilon$ & ו &. .19 & $1 . . \varepsilon$ & $7 . \wedge 1$ & $1 . .9$ & 7.79 & مهارة \\
\hline
\end{tabular}


مجلة بحوث ودراسات الطفولة - كلية التربية للطفولة المبكرة - جامعة الفيوم لـ العدد الخامس عشر

\begin{tabular}{|c|c|c|c|c|c|c|c|c|}
\hline غير & 1.47 & r.VA & .91 & E.rq & $V . \leqslant V$ & $1.1 \%$ & 7.07 & مهارة \\
\hline غير & r.VI & 1.11 & ror & 1.79 & $v . . r$ & $1.4 \varepsilon$ & 7.0. & الاستتناج \\
\hline غالة & r.T. & $r .99$ & א. 1. & O.Y. & $r$ r.rA & r.TI & 19.80 & الاداة ككل \\
\hline
\end{tabular}

يتضح من جدول ( () السابق عدم وجود فرق دال إحصائًًا بين متوسطي درجات أطفال المجموعتين التجريبية والضابطة في التطبيق القبلي لمقياس مهارات الملاحظة

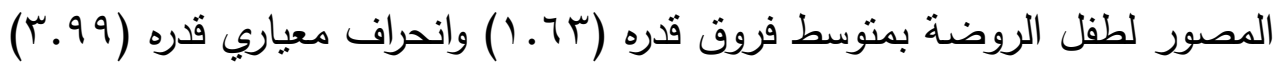
مما يشير إلى تكافؤ أطفال المجموعتين التجربيية والضابطة قبلياً.

\section{أدوات البحث}

1. قائمة مهارات الملاحظة لطفل الروضة. (إعداد الباحثة) r. البرنامج القائم على استراتيجية المحطات العلمية لتطوير مهارات الملاحظة لدى طفل الروضة. (إعداد الباحثة) r. مقياس مهارات الملاحظة المصور لطفل الروضة. (إعداد الباحثة) وفيما يلي وصف تفصيلي لأدوات البحث:

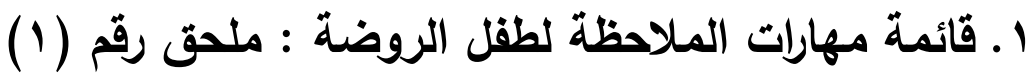
الهذف من القائمة: تحديد مهارات الملاحظة التي يمكن تطويرهـا للدى طفل الروضـة باعتبارها من مهارات التعلم مدى الحياة التي تُستخدم في حل ومعالجة مشكلات الحياة اليومية. خطوات إعداد القائمة: تم تصميم القائمة وفقًا للخطوات التالية: 


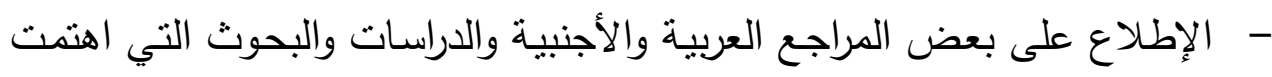

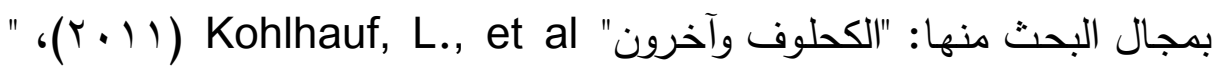

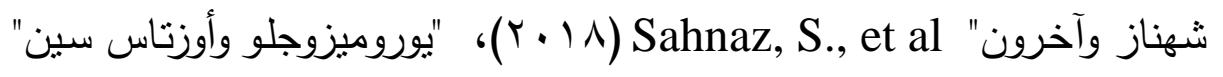

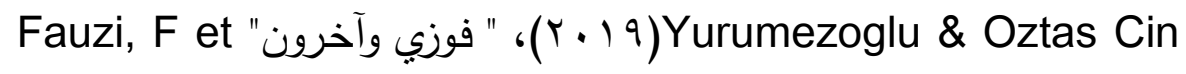

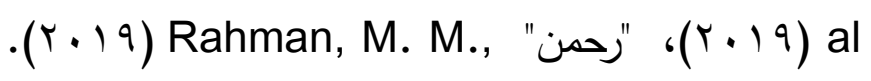

- - إعداد قائمة بمهارات الملاحظة التي يمكن تطويرها لدى طفل الروضـة اشتملت

$$
\text { في صورتها الأولية على (·. (Y) مهارة. }
$$

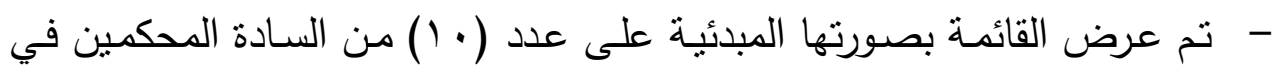
مجال مناهج وطرق تدريس رياض الأطفال وذلك لتحديد أهم مهارات الملاحظة علئ التي يمكن تطويرهـا لـدى طفل الروضــة وإضـافة أو حذف ولف مـا يرونـه مناسباً للقائمة. - تدرجت مستويات القياس تحت ثلاث مستويات: (هامـة جدًا - متوسطة الأهميةقليلة الأهمية).

- مقد تم حساب نسبة الإتفاق بين المحكمين وتضمنت القائمة مهارات الملاحظة التي تزيد نسبة الإتفاق عليها عن ( •9\%).

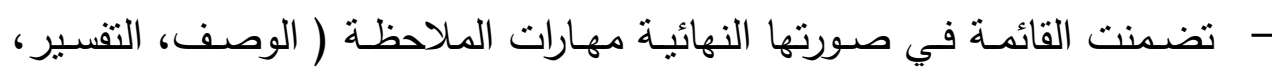
الاستتناج ) والتي يمكن تطويرها لاى طفل الروضة. (ملحق ( )

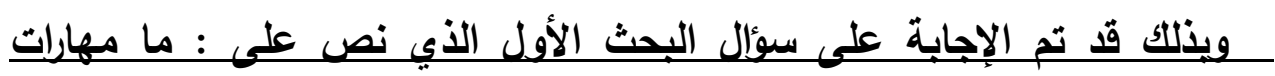
الملاحظة المراد تطويرها لاى طفل الروضة ؟ ويالتالي تحقق الهيف الأول من أهداف البحث وهو : تحدب مهارات الملاحظة المراد تطويرها لاى طقل الروضة. r. البرنامـج القائم على استراتيجية المحطات العلمية لتطوير مهارات الملاحظة لاى طفل الروضة: ملحق رقم (r)

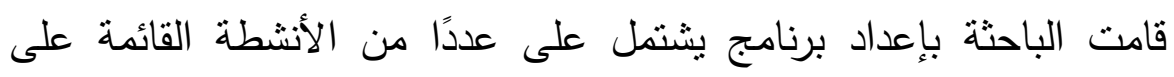

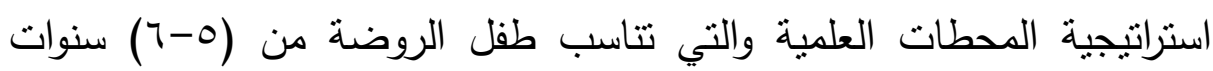

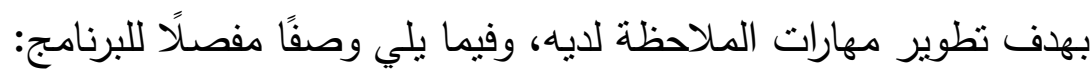


مجلة بحوث ودراسات الطفولة - كلية التربية للطفولة المبكرة - جامعة الفيوم لـ العدد الخامس عثر

\section{الأهداف العامة للبرنامج:}

ا ـ تطوير مهارة تسمية عناصر أو مكونات الموقف التعليمي لدى الطفل.

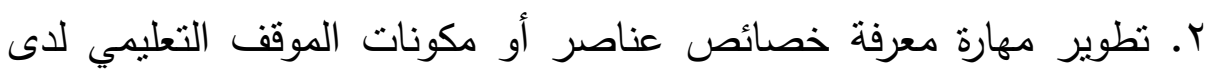
الطفل.

r. تطوير مهارة إيجاد العلاقات بين عناصر أو مكونات الموقف التعليمي لدى الطفل.

ع. تطوير مهارة تحديد أوجه الثبه والاختلاف بين عناصر أو مكونات الموقف التعليمي لدى الطفل.

0. تطوير مهارة استخلاص مفاهيم وقيم وأفكار جديدة حول عناصر أو مكونات الموقف التعليمي لدى الطفل. 7. تطوير مهارة ربط المفاهيم والقيم والأفكار الجديدة بالخبرات السابقة في ضوء لهوعي الحقائق المعطاة حول عناصر أو مكونات الموقف التعليمي لاى الطفل.

الأهداف السلوكية للبرنامج:

اشتمل البرنامج على مجموعة من الأهداف المعرفية والحسحركية والوجدانية تصدرت كل نشاط والتي من المتوقع تحقيقها في نهاية البرنامج والمتعلقة بتطوير مهارات الملاحظة لاى طفل الروضة. القلسفة التريوية للبرنامج: انبثقت الفلسفة التربوية للبرنامج الحالي من: - النظريـة البنائية: والتي مفادهـا أن المتعلم يمتلك معرفـة وخبرات سـابقة تشكلت

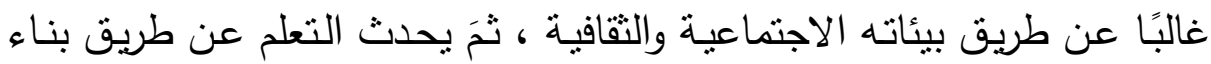
معرفة المتعلمين من خبراتهم ، فالمعرفة تُبنى بصورة نشطة على يد المتعلم ولا

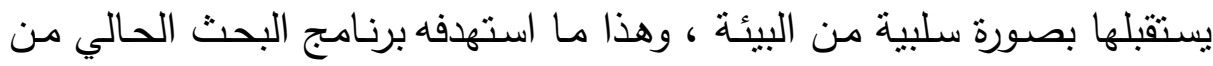

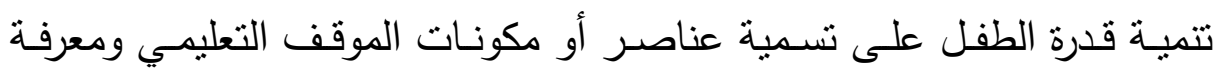
خصائصها وإيجاد العلاقات بينها واستخلاص مفاهيم وقيم وأفكار جديدة وربطها بخبراته السابقة في ضوء الحقائق المعطاة له. 
- - نظرية مونتيسوري التعليمية: والتي تؤكد على أهمية خلق بيئة تعليمية مناسبة

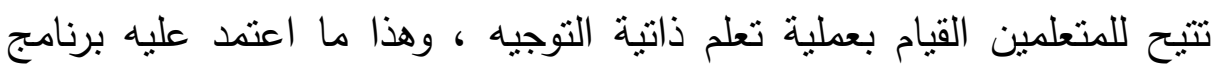
البحث الحالي من تهيئة بيئة تعلم توفر للطفل الفرصة لتطوير مهارات الملاحظة

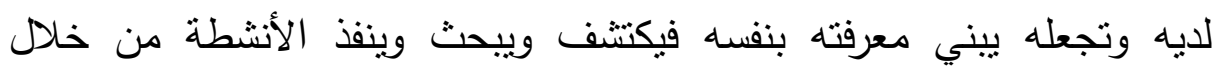
مجموعة من المحطات العلمية الثرية بالخبرات والمحفزة للتعلم. أسس بناء البرنامج:

تم بناء برنامج البحث الحالي استنادًا إلى مجموعة من الأسس منها:

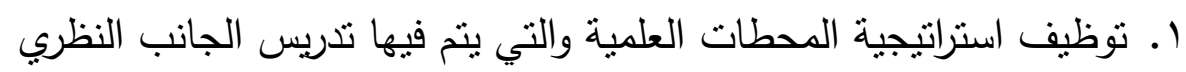
والعملي للمحتوى العلمي.

r. الإعتماد على مجموعة من المجطات العلمية (الاستقصائية/الاستكثافية-

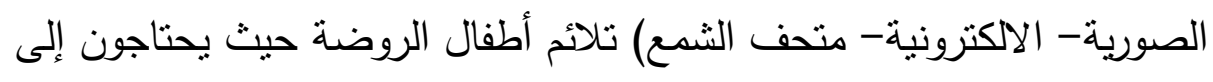
وقت طويل داخل المحطات.

r. مناسبة أنشطة البرنامج لخصائص نمو أطفال الروضة وميولهم وقدراتهم واحتياجاتهم. ـ. مراعاة التسلسل المنطقي في الأنشطة، بحيث تكون منتابعة وكل نشاط يهيئ للذي يليه داخل كل وحدة.

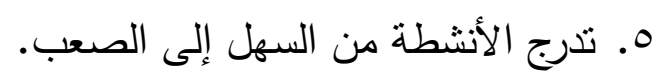

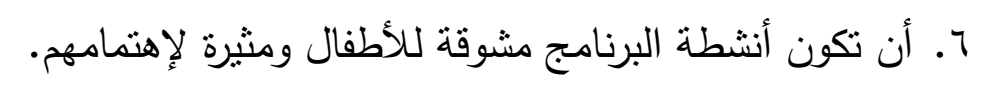
V. نشجيع الأطفال على ممارسة الأنشطة بصورة جماعية. ^. إحتواء البرنامج على مجموعة من الأنشطة التي تتمي إبداع الأطفال وتفكيرهم الناقد. 9. مراعاة عوامل الأمن والسلامة بالنسبة للأدوات والخامات والوسائل التي تم توظيفها في البرنامج. • ا ـ التتوع في الوسائل التعليمية المستخدمة. ا إستخدام أوراق عمل مناسبة ومتتوعة. 
مجلة بحوث ودراسات الطفولة - كلية التربية للطفولة المبكرة - جامعة الفيوم لـ العدد الخامس عشر

محتوى البرنامج:

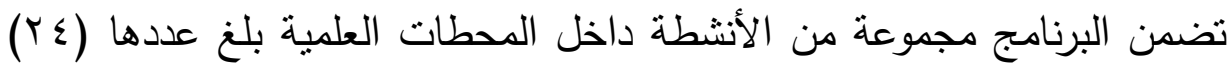
نشاطًا توزعت في ثلاث وحدات رئيسية استهدفت تطوير مهارات الملاحظة لادى دهن

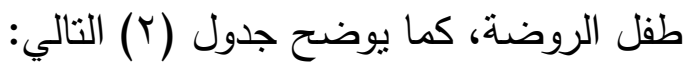

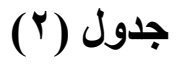

محتوى البرنامج

\begin{tabular}{|c|c|c|c|}
\hline عدد الأنشطة & المحطات العلمية & مهارات الملاحظة & وحدات البرنامج \\
\hline$\wedge$ & \multirow{3}{*}{ 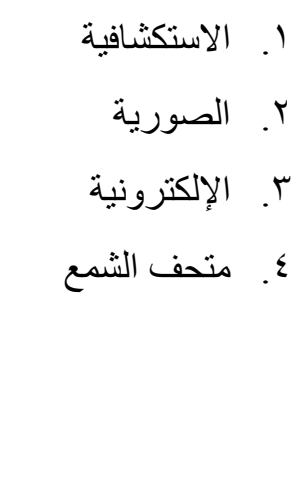 } & \multirow{3}{*}{ 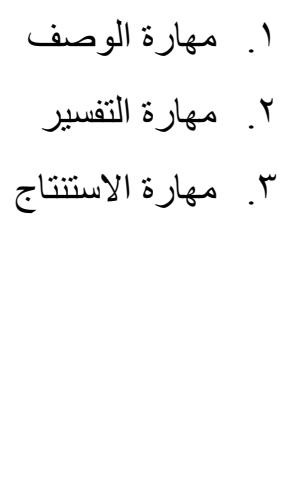 } & الوحدة الأولى: الثجرة \\
\hline$\wedge$ & & & الوحدة الثانية: \\
\hline$\wedge$ & & & الوحدة الثالثة: \\
\hline$r \varepsilon$ & & دد الاجمالي لآنشطة & \\
\hline
\end{tabular}

استراتيجيات تعليم وتعلم أنشطة البرنامج:

تم استخدام مجموعة منتوعة من الإستراتيجيات منها: ( العصف الذهني، الحوار

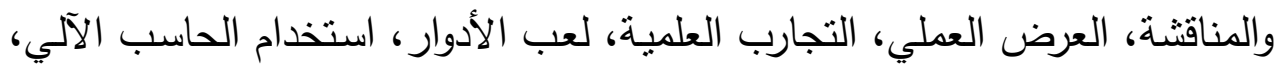
رواية القصة، الأغاني، ... ). الأدوات والوسائل المستخدمة في البرنامج:

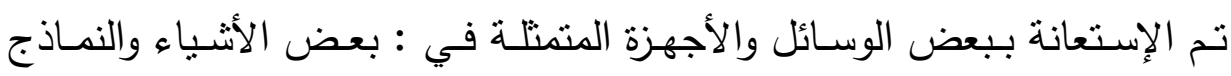

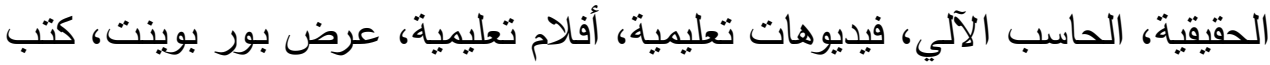


مصورة ، بطاقات مصورة، وبعض الثخصيات المجسمة لطيور وحشرات، بالإضافة إلى بعض البطاقات التقويمية المصورة (أوراق العمل).

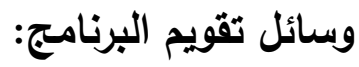

تتوعت وسائل التقويم المستخدمة للحكم على مدى نجاح البرنامج لتشمل: - التقويم القبلي: تم من خلال تطبيق مقياس مهارات الملاحظة المصور للتعرف على خلفية الطفل المعرفية والوقوف على مدى نوافر مهارات الملاحظة لديه. - التقويم المرحلي: وهو تقويم مصاحب من بداية البرنامج وحتى نهايته ونم من خلال: - n

ملاحظة سلوك الأطفال اليومي أثناء تأدية الأنشطة داخل المحطات

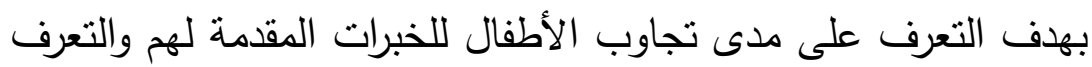
على جوانب القوة والضعف لديهم ومحاولة علاجها.

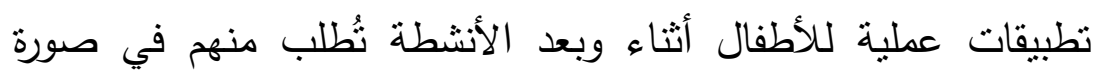
ممارسات ومهام يقومون بأدائها بصورة فردية وجماعية.

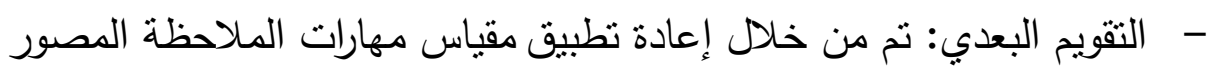
والذي تم تطبيقه قبل تتفيذ البرنامج بهدف معرفة مدى التقدم الذي حققه الأطفال بعد تطبيق البرنامج ومقارنته بقبل التطبيق. عرض البرنامج على السادة المحكمين:

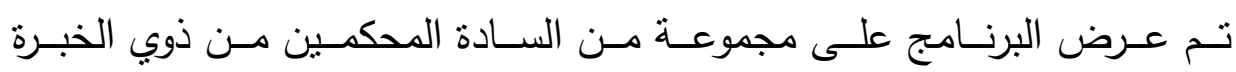
والتخصص في مجال التربية ورياض الأطفال، وذلك لإبداء الرأي حول:

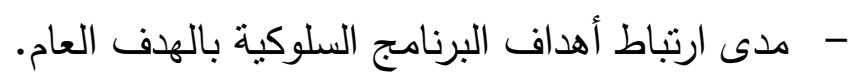
- مدى ملاءمة المحتوى لتحقيق أهداف البرنامج وخصائص الأطفال.

$$
\text { - أي ملاحظات أخرى. }
$$

وقد أبدى السادة المحكمن بعض الملاحظات منها:

- تعديل صياغة بعض الأهداف السلوكية للبرنامج. - حذف بعض العناصر من محتوى أنشطة البرنامج. 
مجلة بحوث ودراسات الطفولة - كلية التربية للطفولة المبكرة - جامعة الفيوم لـ العدد الخامس عثر

- - تعديل بعض أساليب التقويم المستخدمة في البرنامج.

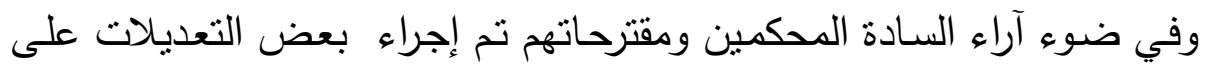

أنشطة البرنامج حتى تتاسب عينة البحث وخصائص نموهم، وبذلك أصبح البرنامج

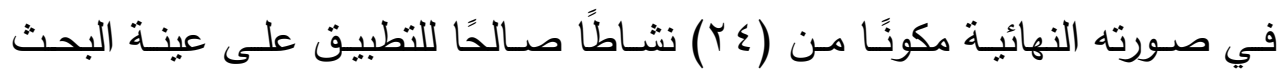

المستهدفة.

\section{الاراسة الاستطلاعية للبرنامه:}

قامت الباحثة بإجراء الدراسة الاستطلاعية للبرنامج على عينة من الأطنام الأطفال

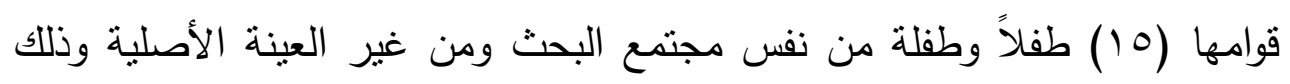
بغرض التحقق من الجوانب التالية: - معرفة مدى ملائمة البرنامج للأطفال.

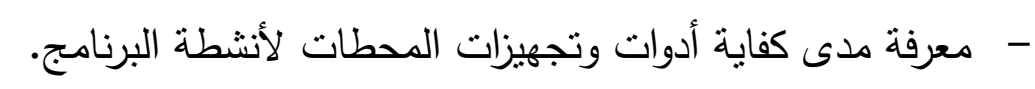

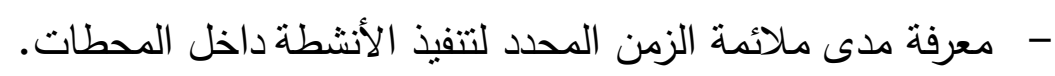
- تحديد الصعوبات التي قد نواجه الباحثة. وفي ضوء نتائج الدراسة الاسنطلاعية توصلت الباحثة لما يلي:

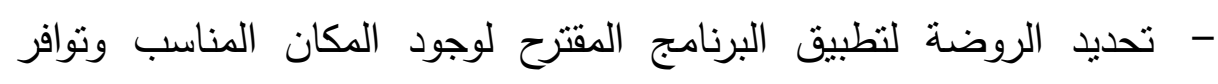
مواصفات العينة وتعاون المعلمات وترحيب إدارة الروضة.

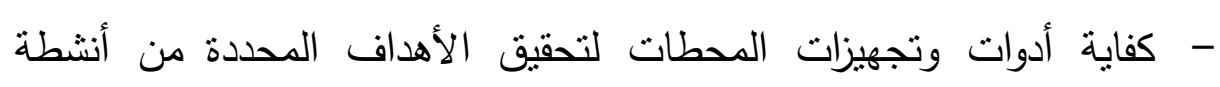

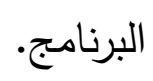

- - تحديد الفترة الزمنية لتطبيق البرنامج. الخطة الزمنية لتنفيذ البرنامج:

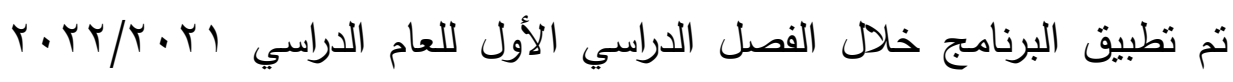

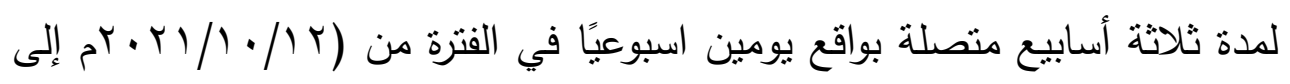

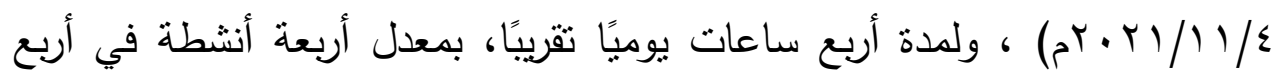

محطات. 


\section{وفيما يلي عرض لأحد أنشطة البرنامج:}

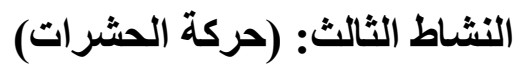
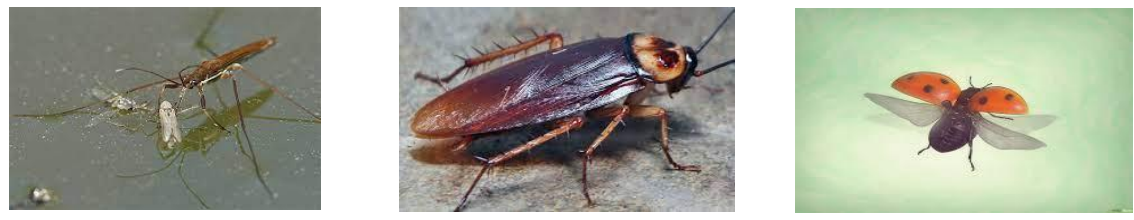

الأهداف الاجرائية:

- - يسمي الطفل طرق تنقل الحشر ات. - - - يقارن الطفل بين كل طريقة. - يستتج الطفل أن لكل حشرة خصائص تمكنها من التحرك. المكان: القاعة الزمن: 0 ـ دقيقة الإلكترونية المواد والأدوات: فيديو تعليمي عن طرق تنقل الحشرات (الطيران- المشي(السباحة). خطوات النشاط: - - تجلس مجمو عة الأطفال على شكل دائرة.

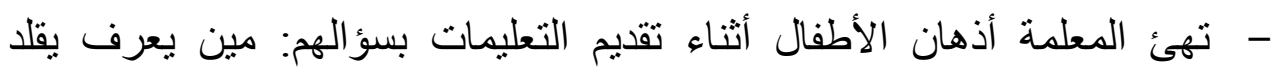

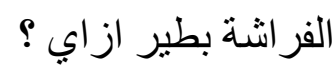

- - تجهز المعلمة فيديو تعليمي عن طرق تنقل الحشرات في هذه المحطة. - يشاهد الأطفال الفيديو التعليمي عن طرق تنقل الحشرات (الطيران- المشيالسباحة) مع محاولة تسميتها. - - تلاحظ المعلمة الأطفال أثناء المقارنة بين خصائص كل طريقة وتتدخل لتوضيح: 1. الطيران: باسستخدام (الأجنحة ـ المفاصل ـ العضلات الظهرية البطنية) حيث ترفع الحشرات أنفسها في الهواء باستخدام أجنحتها الصغيرة ، وهنالك 
مجلة بحوث ودراسات الطفولة ـ كلية التربية للطفولة المبكرة - جامعة الفيوم ] ل العدد الخامس عشر

الكثير من الحثرات الأصغر حجما والعديمة الأجنحة تتنقل باستخدام التيار ات

$$
\text { الهو ائية مقل حشرة (المن). }
$$

ץ. المثي: تعد الصر اصير من أسرع الحثر ات جريا، وهي قادرة عندما تصل لأقصى سر عة أن تعدو على قائمتين لتبلغ بذلك سر عة عالية نسبةً لحجم جسدها. "ب. السباحة: يمتلك الكثير من هذه الفصائل خصائص تمكنها من التحرك تحت الماء، حيث تقوم صغار اليعسوب بالتحرك عن طريق قذف الماء من قناتها المستقبمة.

- - يستتج الأطفال أن لكل حثرة خصائص تمكنها من التحرك بمساعدة الباحثة أو المعلمة أثناء إدارة حلقات المناقشة وتقديم التغذية الر اجعة للأطفال.

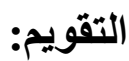

قيام الأطفال بالإجابة على ورقة العمل: ( توصيل كل حشرة بطريقة التحرك المناسبة ل) 


$$
\text { أ.م.د/ سحر فتحي عبد المحن }
$$

وفيمـا يلـي بعض الصـور التـي توضـح مشـاركة الأطفـال عينـة البحث في

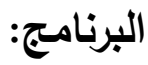
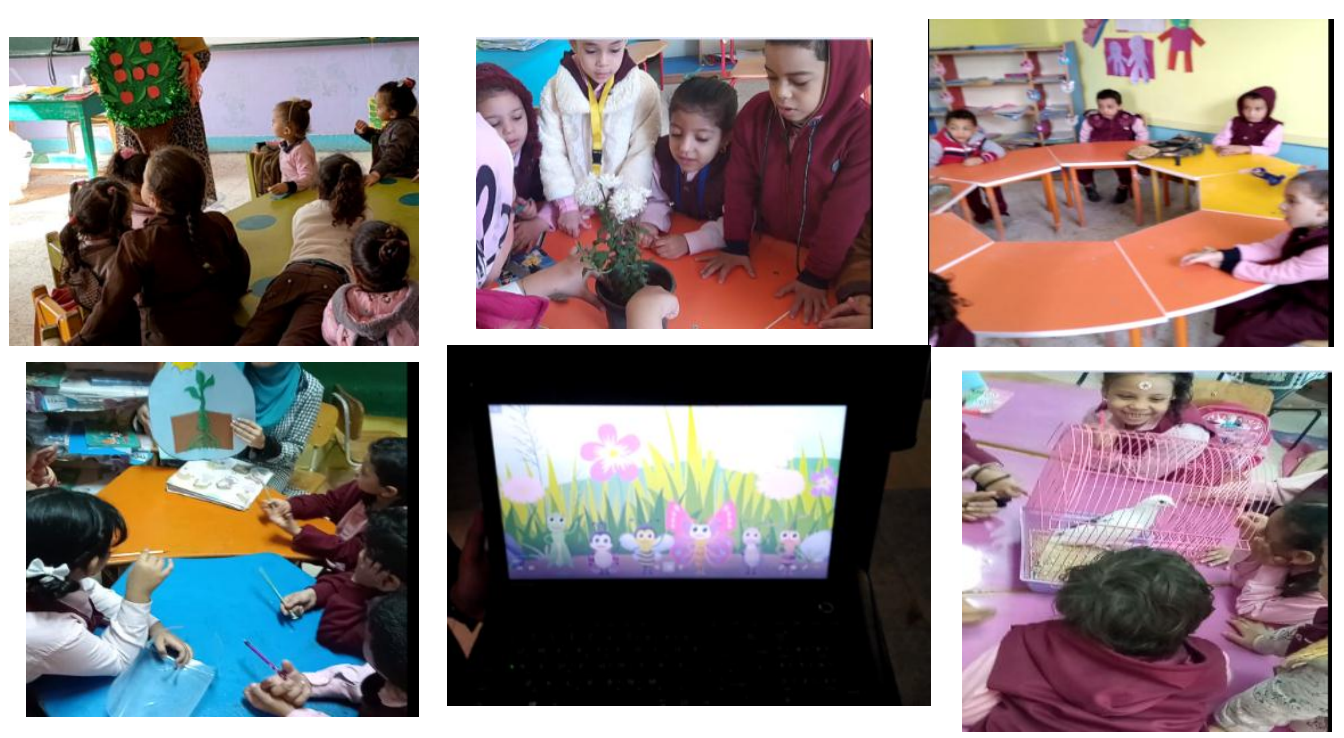

ويذلك قد تم الإجابة على سؤال البحث الثاني الذي نص على : ما التصور المقترح لبرنامج قائم على استراتيحية المحطات العلمية لتطوير مهارات الملاحظة لائ طفل الروضـة ؟ ويالتالي تحقق الهرف الثاني من أهداف البحث وهو : إعداد برنـامجج

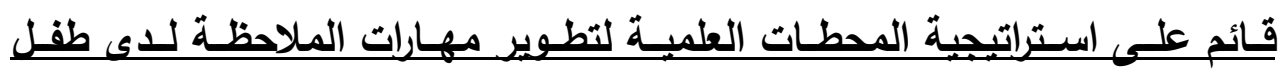
الروضة.

r. مقياس مهارات الملاحظة المصور لطقل الروضة: ملحق رقم (r) الهزف من المقياس:

الكثف عن مستوى توافر مهارات الملاحظة ( الوصف، التفسير ، الاستنتاج ) لاى طفل الروضة.

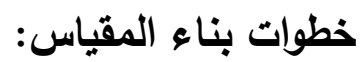
تم إعداد المقياس طبقاً للخطوات التالية: 
مجلة بحوث ودراسات الطفولة - كلية التربية للطفولة المبكرة - جامعة الفيوم لـ العدد الخامس عشر

- الاطلاع على بعض المراجع العربية في القياس النفسي والتربوي للتعرف على كيفية بناء الإختبارات والمقاييس وإعدادها.

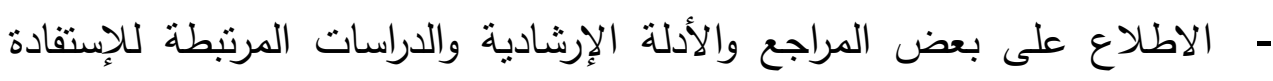

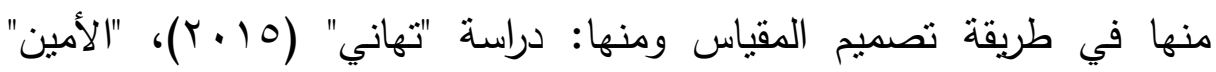

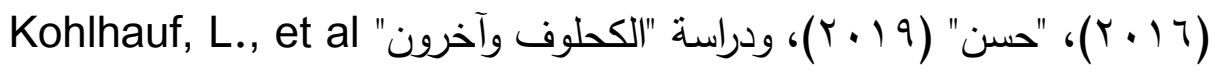

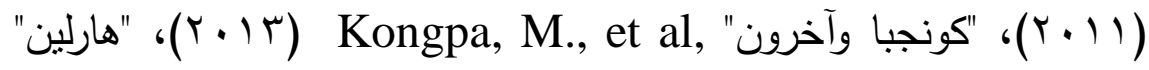

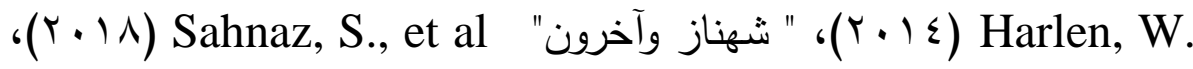

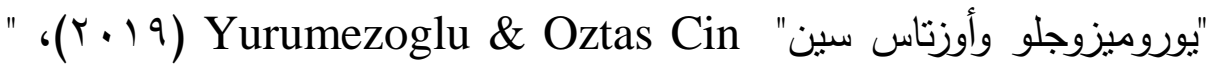

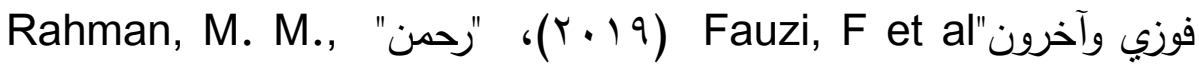
$\cdot(r .19)$ - تكون المقياس في صورته الأولية من مجموعة أسئلة مصورة بلغ عددها (10) سؤال تتدرج تحت ثلاث مهارات للملاحظة ( الوصف، التفسير ، الاستتناج ). - تم عرض المقياس فى صورته المبدئية على مجموعة من الخبراء المتخصصين في رياض الأطفال وعلم النفس ومجال المناهج وطرق التدريس بهدف إبداء

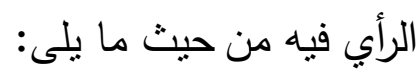
حذف أو إضافة أو تعديل أى سؤال أو صورة لا تتاسب الهدف أو سن الأطفال. التأكد من تحقيق المقياس للهذف المراد قياسه. التأكد من مناسبة الأسئلة وعناصر الصور لأسئ لأطفال الروضة. - وقد طرح السادة المحكمون بعض الملاحظات على المقياس منها: تعديل الصياغة اللغوية لبعض الأسئلة لتناسب طفل الروضة مثل:

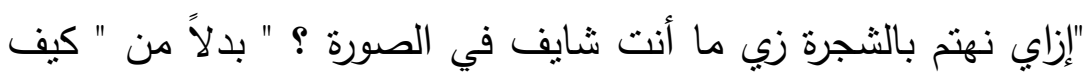

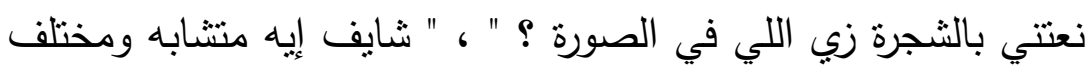

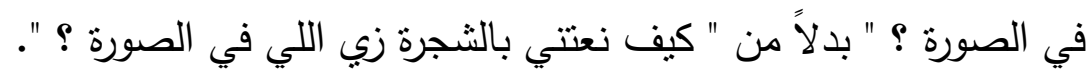
تغيير بعض الصور التي لا نتتاسب مع سن الأطفال. المقياس فى صورته النهائية : 
وقد قامـت الباحثنة بـإجراء كل التعديلات كاملـة وتضـمن المقيـاس فـى صـورته النهائية (0 1) سؤالاً مصوراً عن خبرة "الثجرة" موزعة على مهارات الملاحظة الثلاث

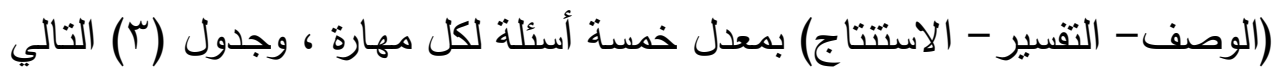
يوضح الثكل النهائي للمقياس:

جدول (r)

الثكل النهائي لمقياس مهارات الملاحظة المصور لطقل الروضة والنسب المئوية لآراء السادة المحكمين

\begin{tabular}{|c|c|c|c|c|}
\hline المئوية & عدألدئلة & رقم & مهارات الملاحظة & b \\
\hline$\%$ ^० & 0 & 0.1 & الوصف & .1 \\
\hline$\% 91$ & 0 & $1 \cdot-7$ & التفسير &.$r$ \\
\hline$\% 9 \varepsilon$ & 0 & 10.11 & الاستتتاج & س \\
\hline
\end{tabular}

يتضـح مـن جدول (r) السـابق أن نسب اتفاق السـادة المحكمين على أبعاد

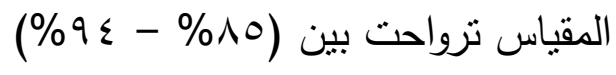

$$
\begin{aligned}
& \text { تعليمات المقياس: }
\end{aligned}
$$

1. التقرب من الطفل وتكوين علاقة إيجابية معهد قبل تطبيق المقياس.

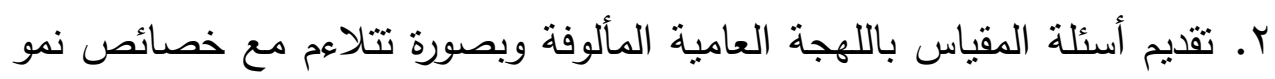
الطفل.

r. وضع كل سؤال في صفحة حتى لا يؤثز ذلك على أداء الأطفال وعدم تركيزهم. ـ. يطبق المقياس بطريقة فردية، ويتم تسجيل إجابات كل طفل في لإني الاستمارة المخصصة له والتي تحتوي على: (مهارات الملاحظة، أسئلة المقياس، إجابات الطفل، الدرجة التي يحصل عليها الطفل في كل سؤال، الدرجة الكلية لكل 
مجلة بحوث ودراسات الطفولة - كلية التربية للطفولة المبكرة - جامعة الفيوم لـ العدد الخامس عثر

\section{تقدير درجات المقياس:}

ينت تصحيح إجابات الطفل وفقًا لثلاثة معايير تحليل تمثل ثناثة مستويات

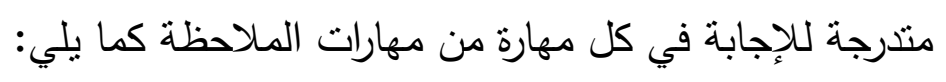
$\checkmark$

1- يحدد الطفل من ثلاثة فأكثر من التفاصيل المختلفة في الموضوع الملاحظ.

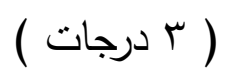

ץ- يحدد الطفل أقل من ثلاثة من التفاصيل المختلفة في الموضوع الملاحظ.

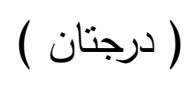

ץ- يحدد الطفل تفاصيل خاظئة أو يعجز عن الإجابة. ( درجة واحدة ) $\checkmark$

ا. يحدد الطفل من ثلاثة فأكثز من أوجه الثبه والاختلاف في الموضوع

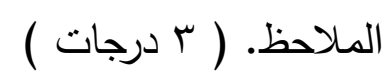

r. يحدد الطفل أقل من ثلاثة من أوجه الثبه والاختلاف في الموضوع

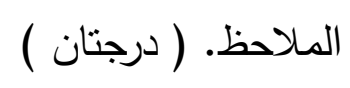

r. يحدد الطفل أوجه شبه واختلاف خاظئة أو يعجز عن الإجابة. ( درجة )

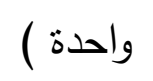

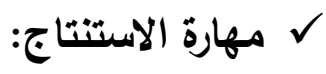

ا. يستخلص الطفل من ثناثة فأكثر من المفاهيم أو القيم أو الأفكار حول

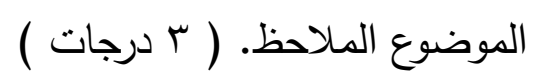

r. يستخلص الطفل أقل من ثثلاثة من المفاهيم أو القيم أو الأفكار حول

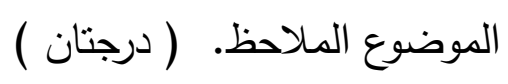

r. يستخلص الطفل مفاهيم أو قيم أو أفكار خاظئة أو يعجز عن الإجابة.

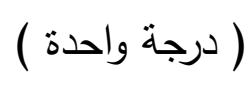




\section{التجربة الاستطلاعية للمقياس:}

تم تطبيق المقياس على عينة استطلاعية بلغ عددها ( . . (1) طفلاً وطفلة

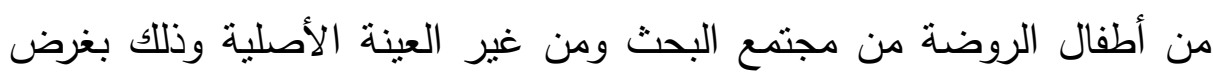

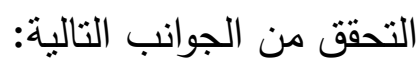
- مدى مناسبة المقياس للأطفال من حيث وضوح الصور وفهم الأسئلة، وقد

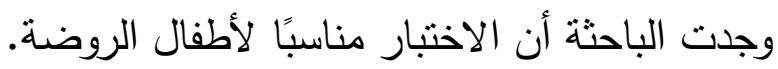
- - مساب المعاملات العلمية للمقياس. زمن تطبيق المقياس:

غير محدد بزمن، حيث يُعطى لكل طفل الوقت الكافي للإجابة على المقياس تبعًا لقدرة كل طفل.

\section{المعاملات العلمية للمقياس:}

قامت الباحثة بإجراء معاملات الصدق والثبات لأسئلة المقياس وذلك على عينة قوامها ( . . (1) طفلاً من غير عينة البحث الأصلية. أ- - مدق المقياس:

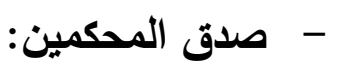

تم عـرض المقيـاس في صـورته المبدئيـة على مجموعـة مـن السـادة المحكمين المتخصصين في المجالات التربوية والنفسية؛ لتحديد صدق المحتوى للمقياس طبقًا

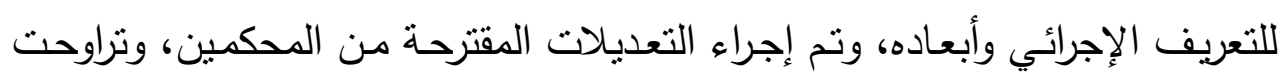
نسبة الاتفاق بينهم على صلاحية المفردات لمقياس مهارات الملاحظة المصور لطفل ولهن الروضة بين (10\%- 9\%) مما بشير إلى صدق مفردات المقياس.

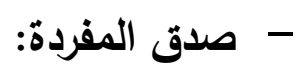

تم تقدير معامل الارتباط بين درجة كل مفردة والدرجة الكلية للبعد الرئيسي الذي

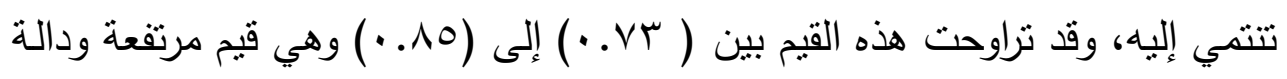
عند مستوى دلالة ا .... كما تم تقدير معامل ارتباط درجة كل بعد رئيسي بالدرجة 
مجلة بحوث ودراسات الطفولة - كلية التربية للطفولة المبكرة - جامعة الفيوم لـ العدد الخامس عشر

الكلية لمقياس مهارات الملاحظة المصور لطفل الروضة وقد كانت جميع هذه القيم دالة عند مستوى دلالة ا +...، وجدول (ع) يبين نتائج ذلك:

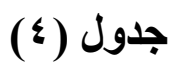

معامل ارتباط الدرجة الكلية للأبعاد بالدرجة الكلية لمقياس مهارات الملاحظة المصور لطقل الروضة

\begin{tabular}{|c|c|}
\hline معامل الارتباط بالدرجة الكلية & أبعاد المقياس \\
\hline $.7 \leq 0$ & مهارة الوصف \\
\hline$\because$ Vro & مهارة التفسير \\
\hline$\because$ V0T & مهارة الاستتناج \\
\hline
\end{tabular}

جدول (0)

معاملات الارتباط بين درجة كل مفردة ودرجة البعد الاول (مهارة الوصف)

\begin{tabular}{|c|c|c|}
\hline درجة الدلالة & معامل الارتباط & مفردات البعد \\
\hline$\cdot .1$ & $* * . .7 \leq 1$ & 1 \\
\hline$\because 1$ & $* * . .7 \wedge$ & r \\
\hline$\because 1$ & $* * \vee q 4$ & $r$ \\
\hline$\because \cdot 1$ & $* * . . \Delta V V$ & $\varepsilon$ \\
\hline$\because 1$ & $* * .70 Y$ & 0 \\
\hline
\end{tabular}

يلاحـظ مـن نتـائج جـدول (0) السـابق أن جميـع معـاملات ارتبـاط بيرسـون

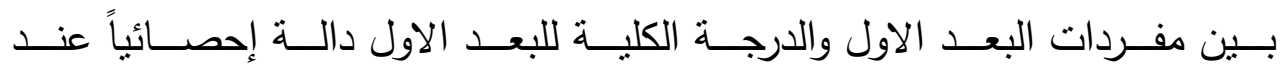




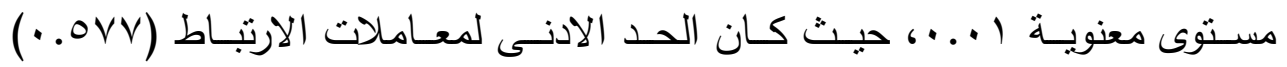

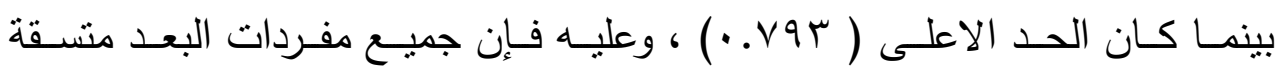

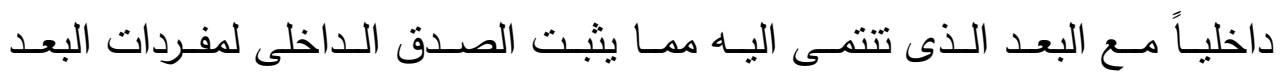
الأول.

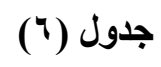

معاملات الارتباط بين درجة كل مفردة ودرجة البعد الثاني (مهارة التقسير)

\begin{tabular}{|c|c|c|}
\hline درجة الدلالة & معامل الارتباط & مفردات البعد \\
\hline$\because \cdots$ & $* * .07 V$ & 1 \\
\hline$\because+1$ & $* * \cdot . \wedge \wedge \mu$ & r \\
\hline$\because \cdot 1$ & $* * \vee \wedge$. & $\mu$ \\
\hline$\because \cdots$ & $* * \wedge \leftrightarrow \wedge$ & $\varepsilon$ \\
\hline$\because \cdot 1$ & $* * \cdot .0 \wedge 1$ & 0 \\
\hline
\end{tabular}

يلاحـظ مـن نتـائج جـدول (T) السـابق أن جميـع معـاملات ارتبـاط بيرسـون

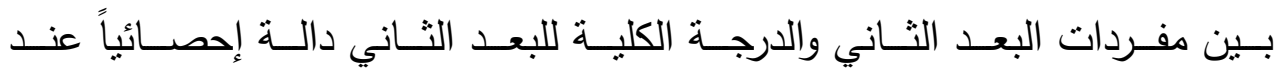

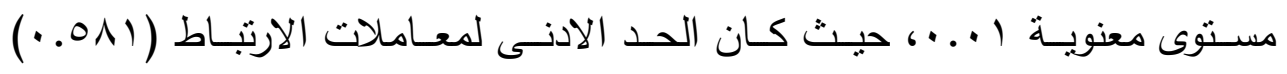

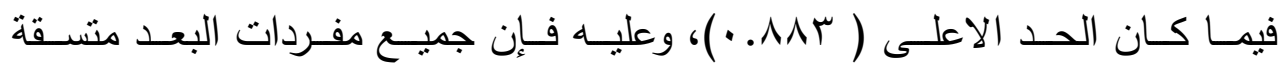

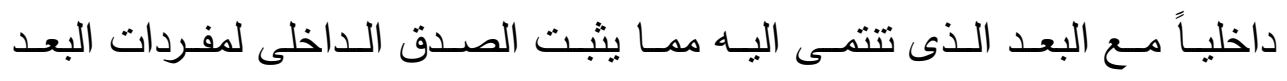
الثاني. 
مجلة بحوث ودراسات الطفولة - كلية التربية للطفولة المبكرة - جامعة الفيوم لـ العدد الخامس عشر

جدول (v)

معاملات الارتباط بين درجة كل مفردة ودرجة البعد الثالث (مهارة الاستتناج)

\begin{tabular}{|c|c|c|}
\hline درجة الدلالة & معامل الارتباط & مفردات البعد \\
\hline$\because \cdot 1$ & $* * . .711$ & 1 \\
\hline$\because \cdot 1$ & $* *, . V Y Y$ & r \\
\hline$\because \cdot 1$ & $* * 799$ & $r$ \\
\hline$\because \cdot 1$ & $* *, . V \circ \varepsilon$ & $\varepsilon$ \\
\hline$\because \cdot 1$ & $* * . \wedge 1 \mu$ & 0 \\
\hline
\end{tabular}

يلاحـظ مـن نتـائج جـدول (V) السـابق أن جميـع معـاملات ارتبـاط بيرســون

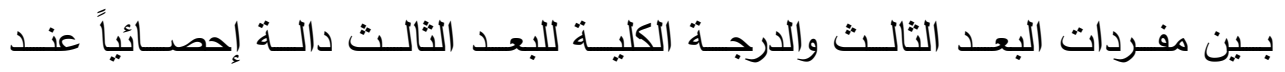

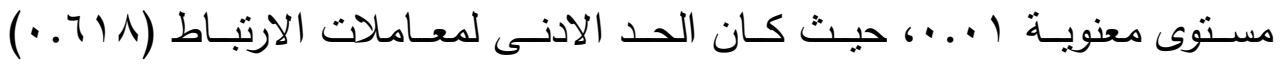

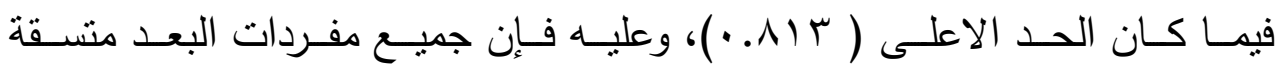

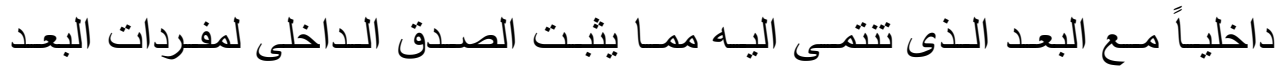
الثالث.

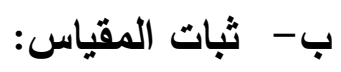

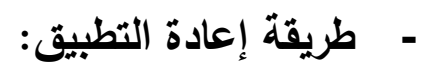

وقـد تـم حســاب معامـل الارتبـاط بــين التطبيــق الاول والثــانى علـى عينــة

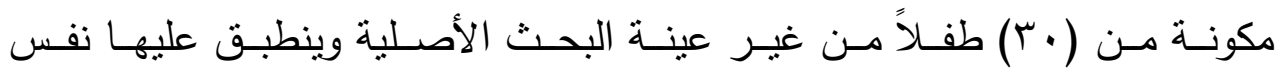
شروط العينة الأصلية، كما يتضح في جدول (^) التالي: جدول (^) معامل الثبات بطريقة إعادة التطبيق 
أ.م.د/ سحر فتحي عبد المحسن

فعالية برنامج قائم على استراتيجية المحطات العلمية

\begin{tabular}{|c|c|}
\hline معامل الارتباط & أبعاد المقياس \\
\hline$* *$ * . $1 \wedge$ & مهارة الوصف \\
\hline$* *, \vee \neg \varepsilon$ & مهارة التفسير \\
\hline$* * . \vee \vee q \vee$ & مهارة الاستنتاج \\
\hline
\end{tabular}

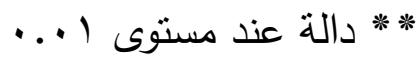

يتضح من جدول (^) السابق ارتفاع معاملات الارتباط مما يدل على ثبات المقياس.

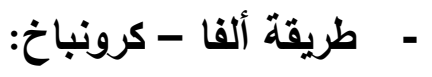

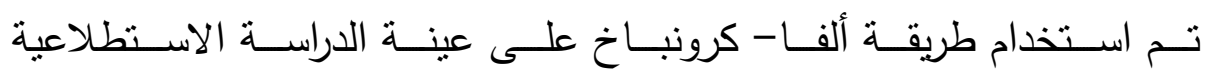

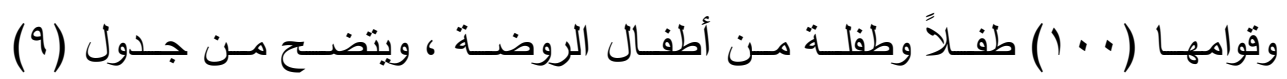

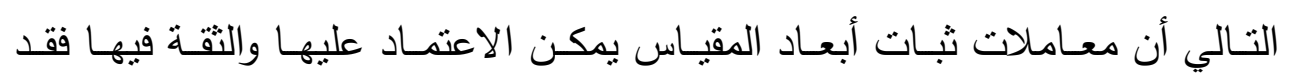

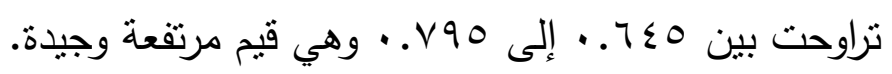

جدول (9)

معاملات ثبات المقياس بطريقة ألفا - كرونباخ

\begin{tabular}{|c|c|}
\hline معامل الثبات بطريقة ألفا_كرونباخ & أبعاد المقياس \\
\hline $.7 \leq 0$ & مهارة الوصف \\
\hline$\because$ Vro & مهارة التفسير \\
\hline. V0T & مهارة النتائج \\
\hline .1990 & الارجة الكلية \\
\hline
\end{tabular}

وفيما يلي عرض لبعض مفردات مقياس مهارات الملاحظة المصور:

o مهارة الوصف: شايف إيه في الصورة ؟ وبتتكون من إيه ؟

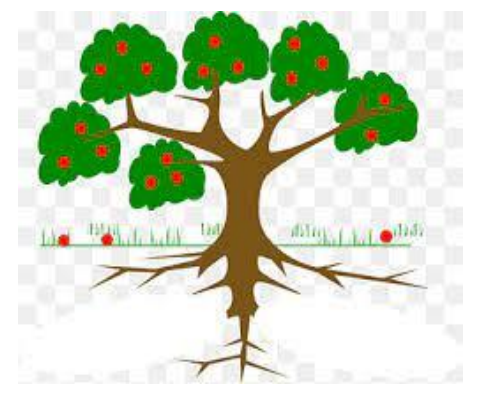




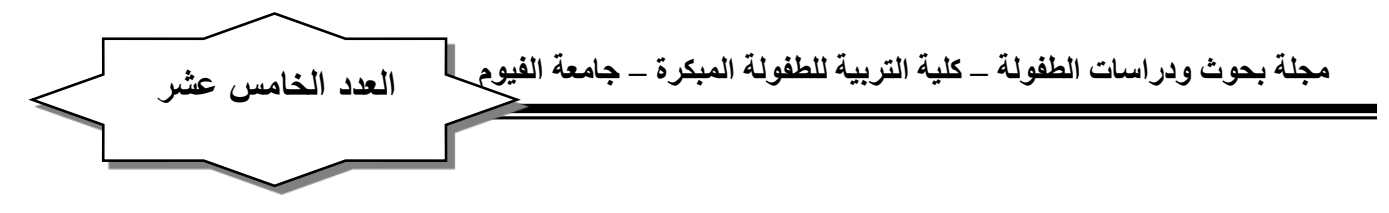

o مهارة التفسير : شايف إيه منشابه ومختلف في الصورة ؟
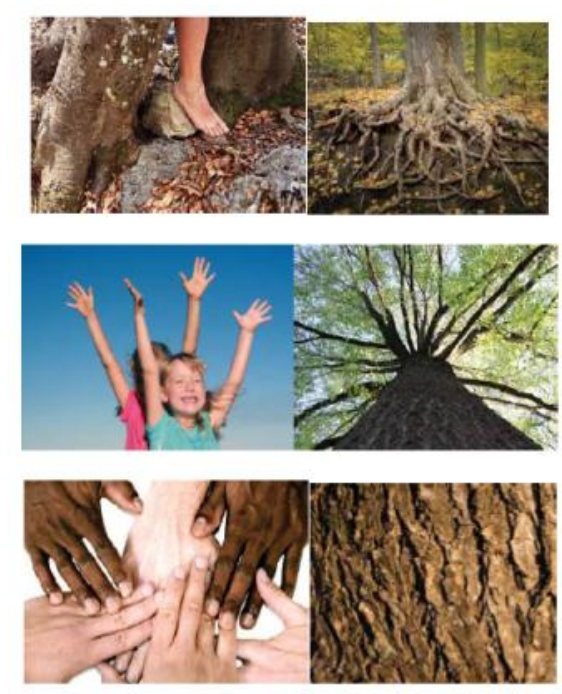

م مهارة الاستتاج: إيه أهمية الثحرة اللي أنت شايفها في الصورة ؟

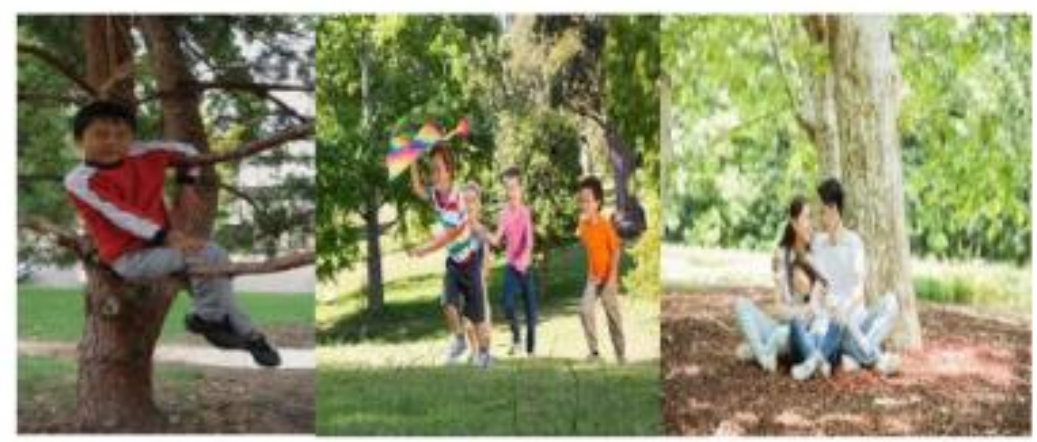

\section{إجراءات البحث الميدانية:}

اتبعت الباحثة عددًا من الإجراءات نشمل ما يلي:

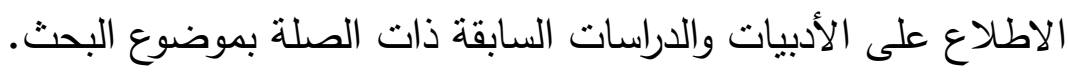

إعداد قائمة مهارات الملاحظة لادى طفل الروضئة

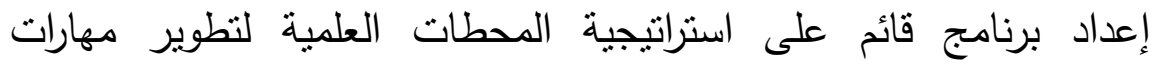

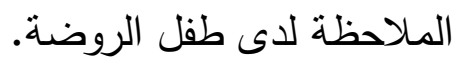


القيام بالدراسة الاستطلاعية للبرنامج.

بناء مقياس مهارات الملاحظة المصور لطفل الروضة. التحقق من صدق وثبات المقياس بالأساليب الإحصائية المناسبة.

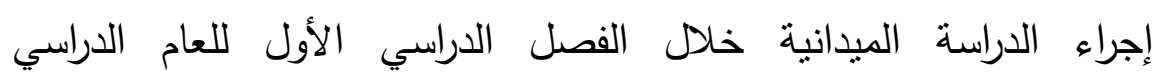

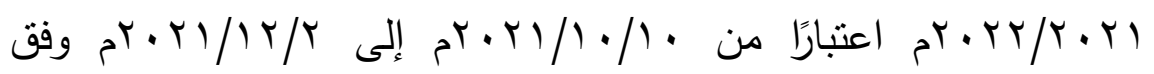

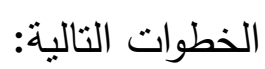

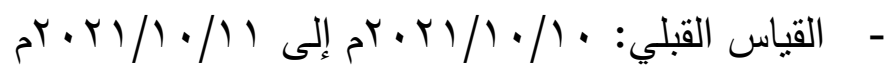

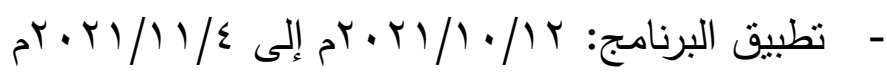

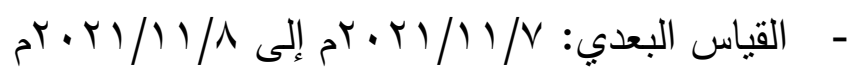

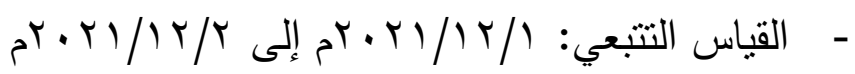

\section{تتائـــج البحـث: تفسيرها ومناقشتهـا}

ولإجابة على السؤال الثالث للبحث والذي نص على : ما فعالية البرنامج القائم

على استراتيجية المحطات العلمية في تطوير مهارات الملاحظة لاى طفل الروضة

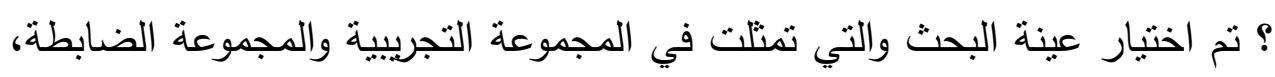
وتم تطبيق مقياس مهارات الملاحظة المصور قبلياً على عينة البحث، ثم تم تتفيذ البرنامج القائم على استراتيجية المحطات العلمية على المجموعة التجريبية، ثم إعادة

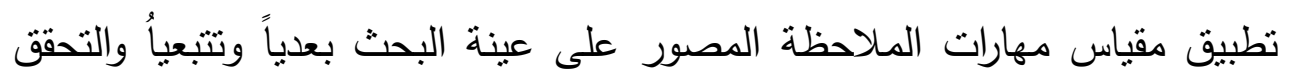
من صحة فروض البحث كما يلي : الفرض الأول:

يوجد فرق دال إحصائيًا بين متوسطي درجات أطفال المجموعة التجريبية والضابطة في القياس البعدي على مقياس مهارات الملاحظة المصور لطفل الروضة لصالح المجموعة التجريبية. 
مجلة بحوث ودراسات الطفولة ـ كلية التربية للطفولة المبكرة - جامعة القيوم) لـ العدد الخامس عشر

وللتحقق مـن صـحة هذا الفرض تم اسـتخدام اختبـار "T-Test" للعينـات غير

المرتبطة، ويوضح جدول (· ( ) التالي نتائج ذلك:

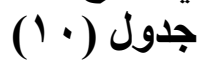

نتائج اختبار "T-Test" لالالة الفرق بين متوسطي درجات أطفال المجموعة التجريبية

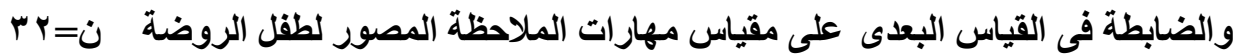

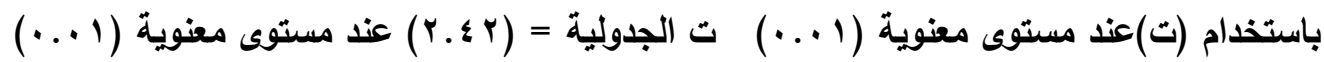

\begin{tabular}{|c|c|c|c|c|c|c|c|c|c|}
\hline \multirow{2}{*}{ الداه الداه } & \multirow{2}{*}{ مستوى } & \multirow{2}{*}{ قيمة Tحسوبة } & \multirow{2}{*}{ اللفرق الانحراف } & \multirow{2}{*}{ متوسط } & \multicolumn{2}{|c|}{ الجمموعة الضابطة } & \multicolumn{2}{|c|}{ الجمموعة التجريبية } & \multirow{2}{*}{ أبعاد } \\
\hline & & & & & الانحراف & الحسابي & المعياري & الحسابي & \\
\hline التجى التجاه & مستوى 1 دالة عن & 19.99 & 1.9. & ד. $\leqslant 1$ & ד. & v. & $\because 1$ & $1 \leqslant .4$ & البهارة \\
\hline التمى الجماه & مستوى & IV.qT & ५. . q & זי. & $1.0 \mathrm{~V}$ & v.ru & $\because 1$. & $1 \% .9 \leqslant$ & الثانى التفان \\
\hline التمى الجماه & دمند دالة عن & $19 . \% \mathrm{~V}$ & I.Av & 8.00 & $1 . r 1$ & Y.YY & 1.11 & Ir.Vr & الثهارث \\
\hline
\end{tabular}




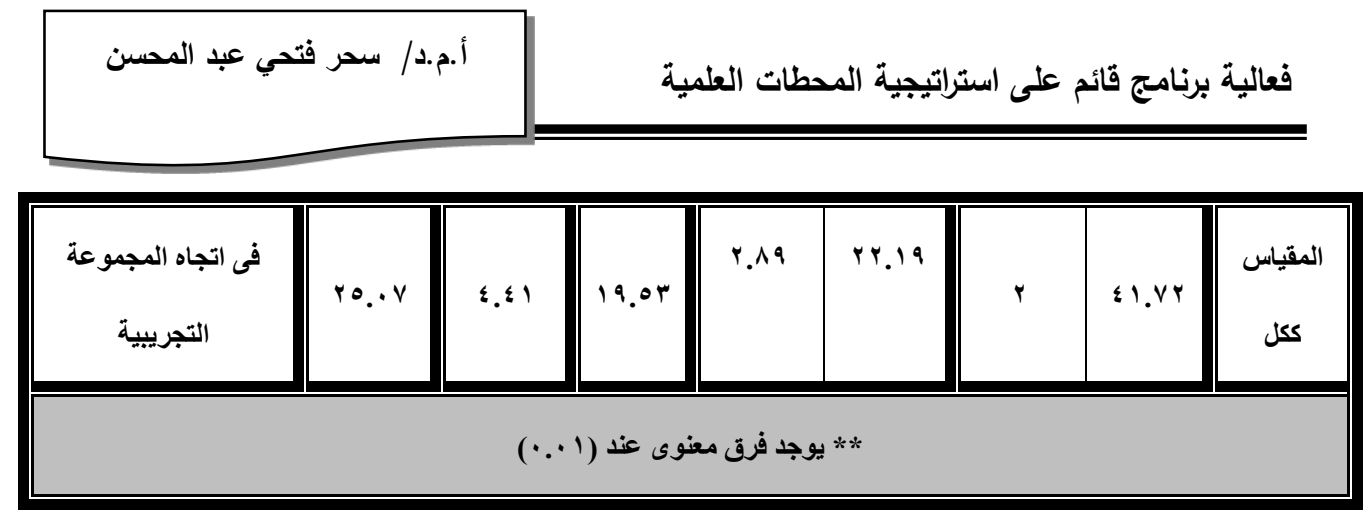

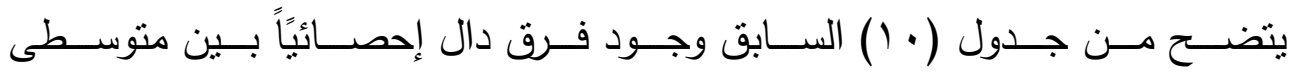

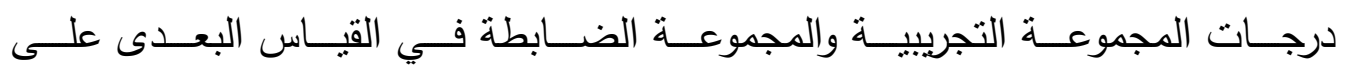

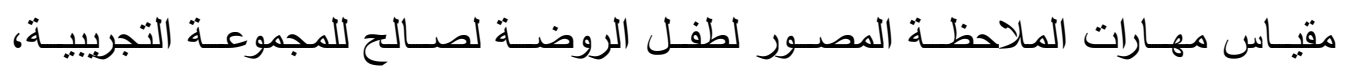
ويذلك يتحقق الفرض الأول للبحث.

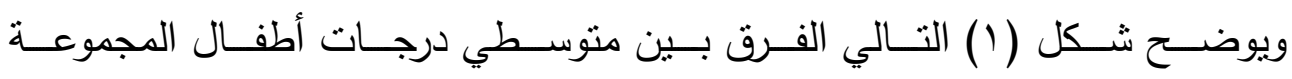

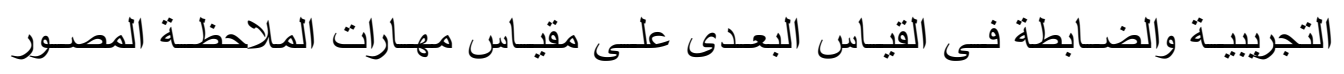
لطفل الروضة عند مستوى معنوية (1 ل...):

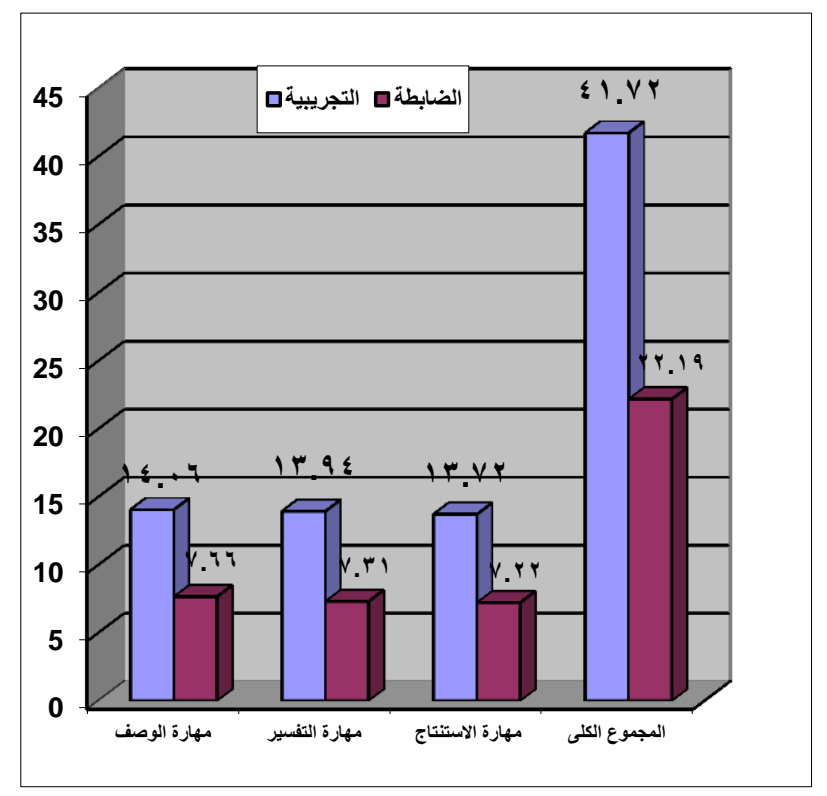

شكل (1)

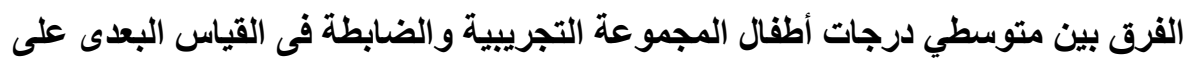
مقياس مهارات الملاحظة المصور لطفل الروضة الفرانة 
مجلة بحوث ودراسات الطفولة ـ كلية التربية للطفولة المبكرة - جامعة الفيوم لـ العدد الخامس عثر

الفرض الثاني:

يوجد فرق دال إحصائيًا بين متوسطي درجات أطفال المجموعة التجريبية في القياسين القبلي والبعدي على مقياس مهارات الملاحظة المصور لطقل الروضة لصالح القياس البعدي.

وللتحقق من صحة هذا الفرض تم استخدام اختبار "T-Test" للعينات المرتبطة، ويوضح جدول (ll (1) التالي نتائج ذلك: هدرئ

جلول (11)

نتائج اختبار "T-Test" لدلالة الفرق بين متوسطي درجات أطفال المجموعة التجريبية في

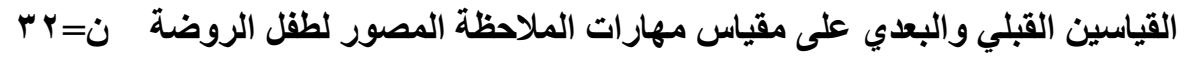

\begin{tabular}{|c|c|c|c|c|c|c|c|c|c|}
\hline \multirow{2}{*}{ الداه } & \multirow{2}{*}{ مستوى } & \multirow{2}{*}{ قيمة T Tسية } & \multirow{2}{*}{ 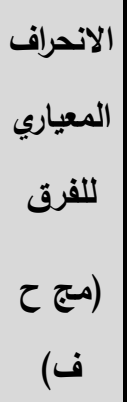 } & \multirow{2}{*}{ متوسط } & \multicolumn{2}{|c|}{ المجموعة التجريبية } & \multicolumn{2}{|c|}{ المجموعة التجريبية } & \multirow{2}{*}{ أبعاد } \\
\hline & & & & & الانحراف & الحستوسط & المعياري & الحستبط & \\
\hline التى اتجاه & معند معند & YT.YV & 1.79 & $7.9 \mathrm{~V}$ & $1 . .9$ & V.. 9 & 1.1. & $1 \leq . .7$ & مهارة الأول \\
\hline فلى التجاه & معند معند & r. T. P & 1.91 & $7.9 \mathrm{~V}$ & $1 . \varepsilon$. & $7.9 V$ & 1.1. & $14.9 \leq$ & الثهارة الثبد \\
\hline
\end{tabular}




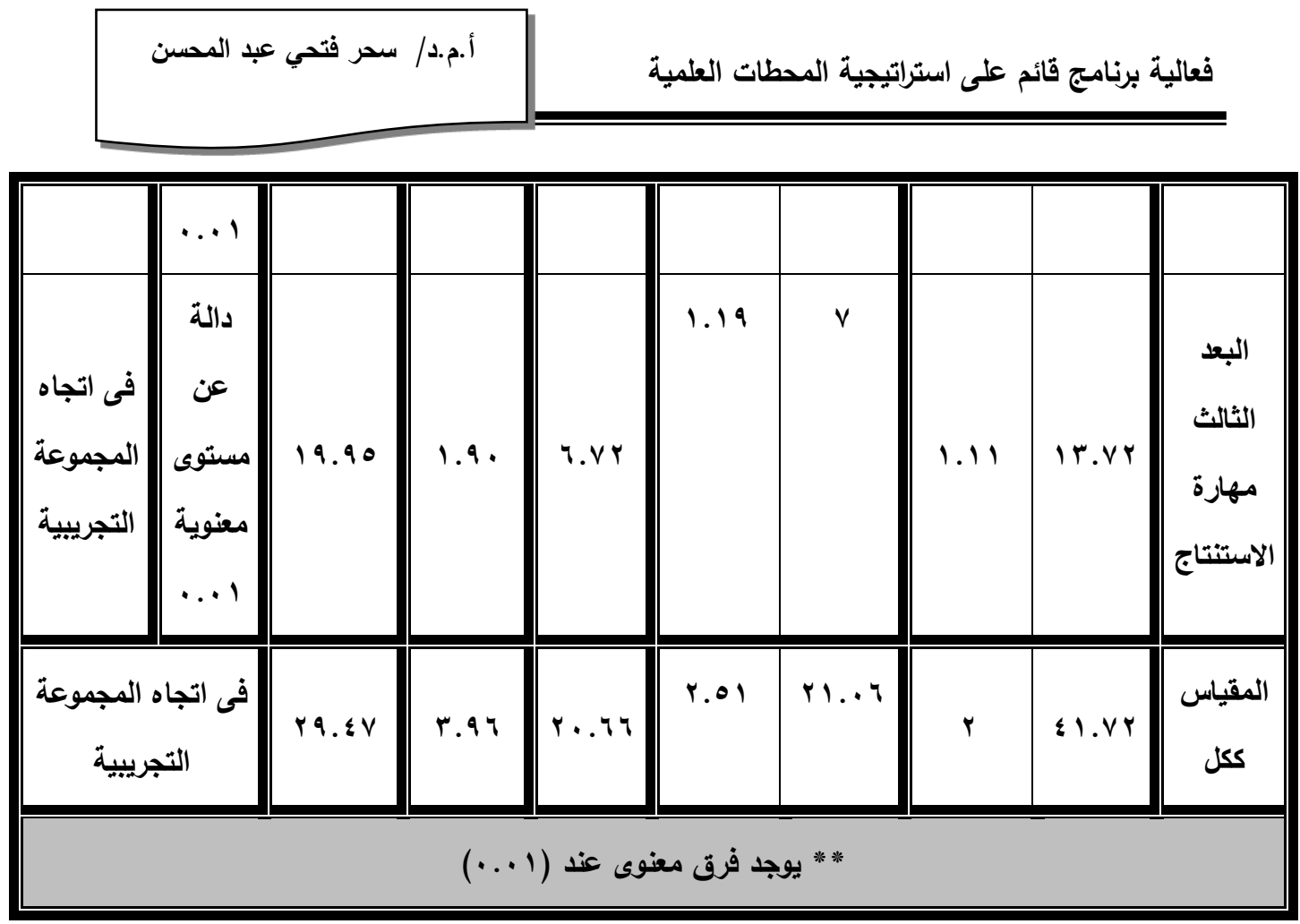

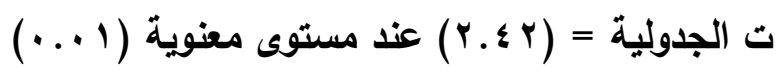

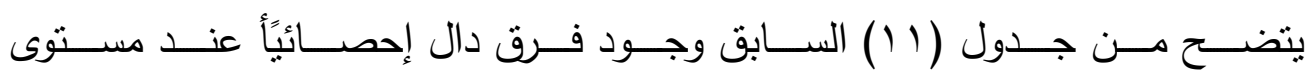

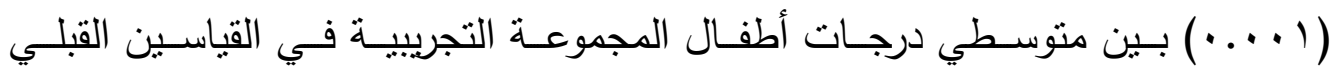
والبعـدي على مقيـاس مهـارات الملاحظـة المصـور (الوصـف، التفسـير ، الاسـتنتاج) لصالح القياس البعدى، ويذلك يتحقى الفرض الثاني للبحث.

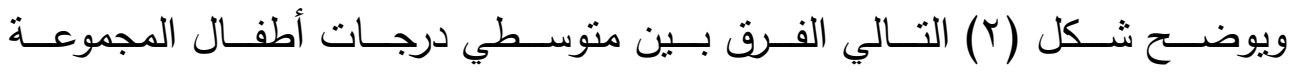
التجريبية في القياسين القبلي والبعدي على مقياس مهارات الملاحظة المصور : 
مجلة بحوث ودراسات الطقولة ـ كلية التربية للطفولة المبكرة - جامعة الفيوم ] ل العدد الخامس عشر

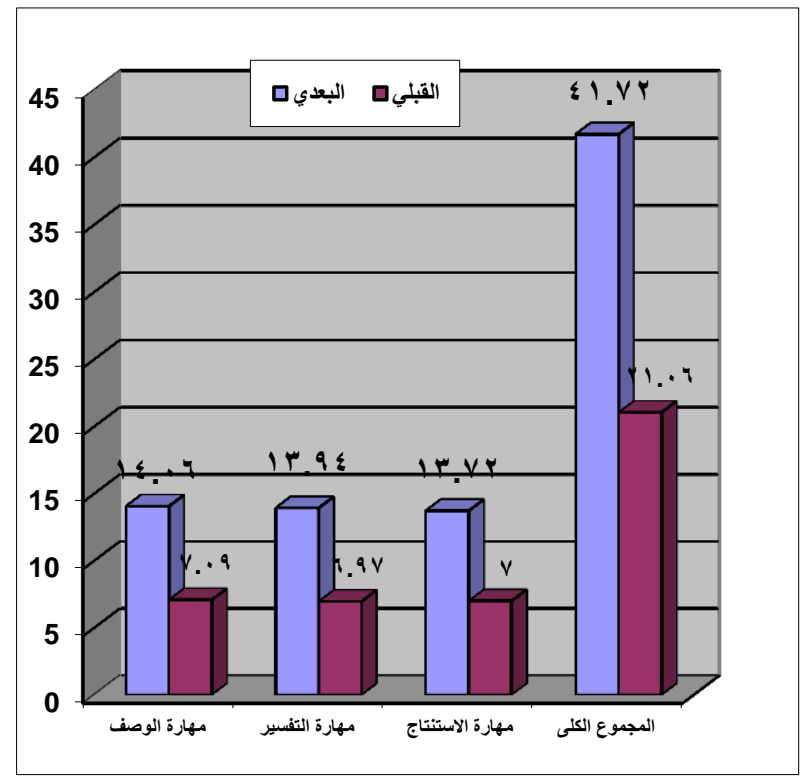

(Y) شكل (1)

الفرق بين متوسطي درجات أطفال المجموعة التجريبية في القياسين القبلي والبعدي على مقياس مهار ات الملاحظة المصور

ثم قامت الباحثة بإبجاد نسبة التحسن بين متوسطي درجات المجموعة التجريبية في القياسين القبلي والبعدي على مقياس مهارات المالاحظة المصور كما يتضـح من جدول (r I) التالي: - (ب) 
أ.م.د/ سحر فتحي عبد المحسن

جدول (r ا ( )

نسبة التحسن بين متوسطي درجات المجموعة التجريبية في القياسين القبلي والبعدي على مقياس مهارات الملاحظة المصور

\begin{tabular}{|c|c|c|c|c|c|c|c|}
\hline الترتيب & | & | الاداء فى & متوسط & الألداء فى القبلى & قتوسط قمبس & المتغيرات & e \\
\hline 1 & $\% \leq 4 . \leqslant$ & $\%$ \%५. . & $1 \leq . .7$ & $\% \leqslant V . r$ & v.. 9 & البعد الأول مهارة الوصف & 1 \\
\hline ا امكر & $\% \leq 4 . \&$ & \%qr.q & $1+.9 \varepsilon$ & $\%$ \% ४.० & $9.9 \mathrm{~V}$ & البعد الثانى مهارة التفسير & $r$ \\
\hline r & $\% \leq \varepsilon . \Lambda$ & $\% 91.0$ & IT.VY & $\% \leq 4 . \vee$ & $v$ & لبعد الثالث مهارة الاستنتاج & $r$ \\
\hline & $\% £ 0.9$ & \%qr.v & $\varepsilon 1 . v r$ & $\%$ \% ४. & r... T & \multicolumn{2}{|c|}{ الارجة الكلية للمقياس ككل } \\
\hline
\end{tabular}

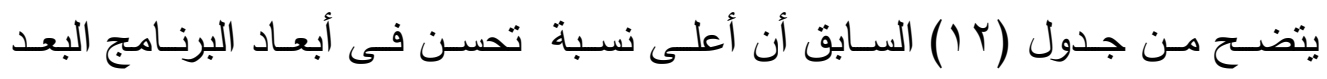

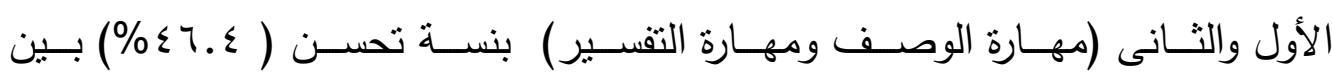

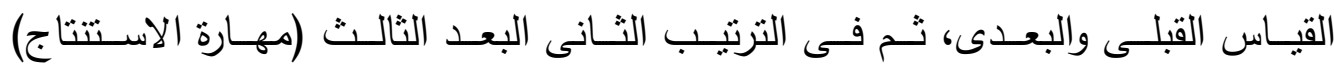
بنسبة تحسن ( ^.ء ؛ـ\%) بين القياس القبلى والبعدى.

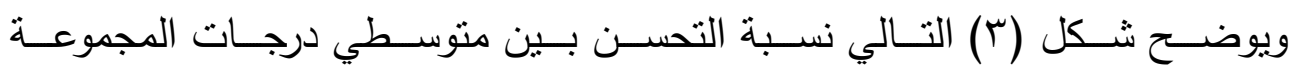
التجريبية في القياسين القبلي والبعدي على مقياس مهارات الملاحظة المصور : 


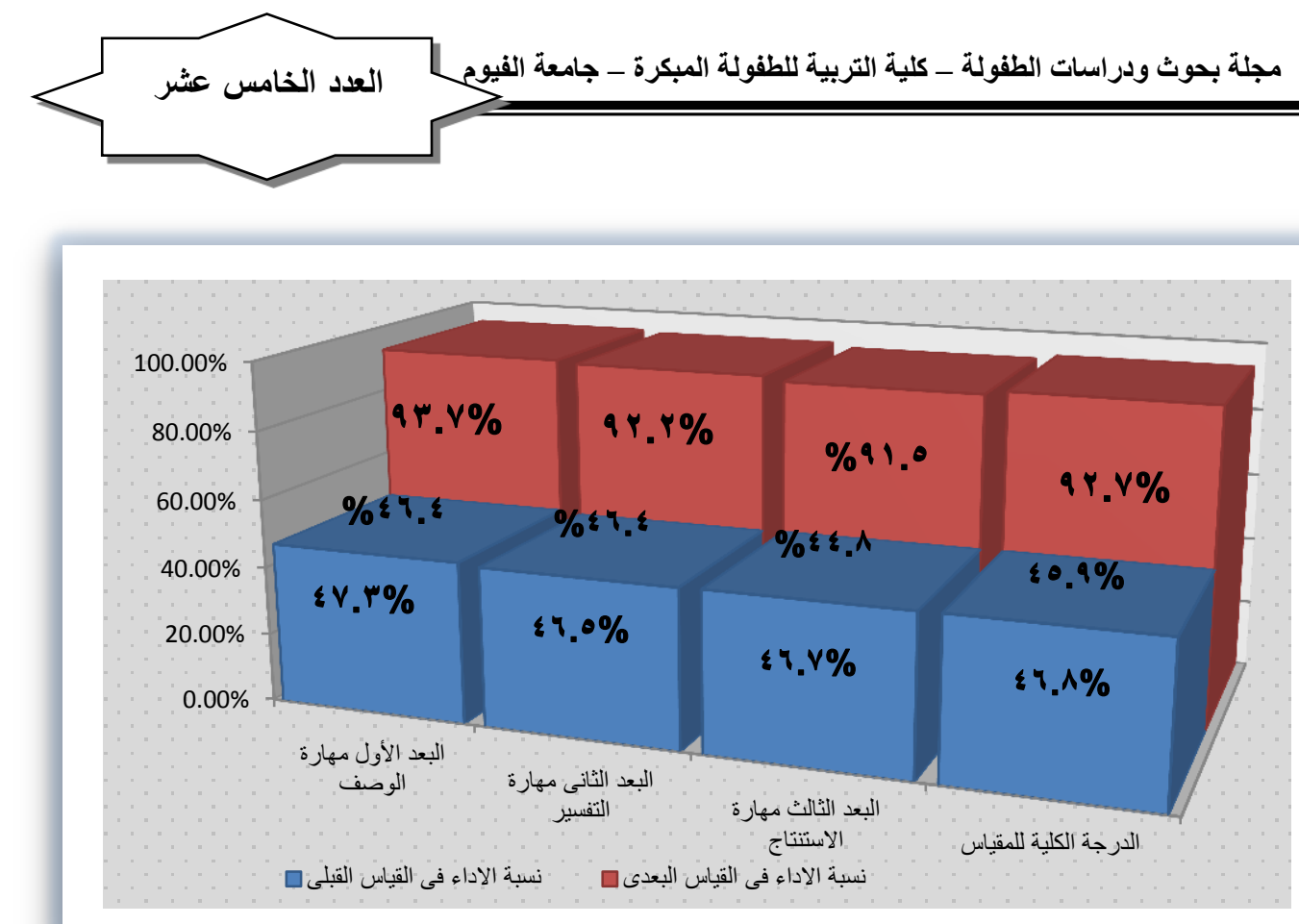

شكل (r) (c)

نسبة التحسن بين متوسطي درجات المجموعة التجريبية في القياسين القبلي والبعدي على مقياس مهار ات الملاحظة المصور

تفسير ومناقشة نتائج الفرض الأول والثاني :

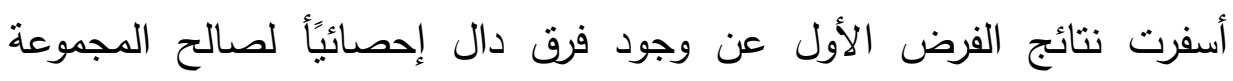
التجريبية مقارنة بالمجموعة الضابطة على مقياس مهارات الملاحظة المصور لطفل

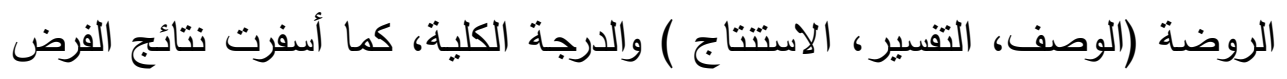
الثاني عن وجود فرق دال إحصائًًا بين متوسطي درجات المجموعة التجريبية في

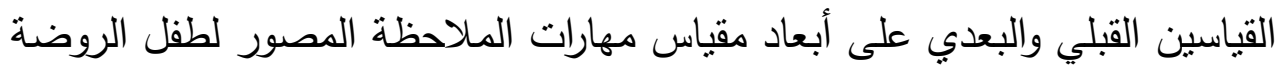
والمقياس ككل لصالح القياس البعدي، وهذا يثير إلى وجود أثز موجب ودادي ودال لتأثير

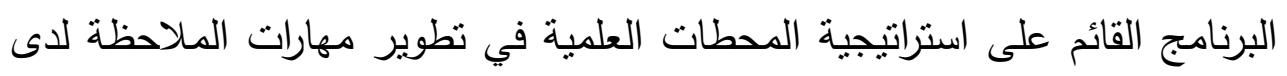
طفل الروضة (عينة البحث). وتُرجع الباحثة تفوق أطفال المجموعة التجربيية مقارنة بأطفال المجموعة الضابطة إلى أهمية تتاول موضوع تطوير مهارات الملاحظة فهو من الموضوعات الضرورية 
لأطفال الروضة، وتعتبر من أهم مهارات العلم الأساسية ومهارات التعلم مدى الحياة

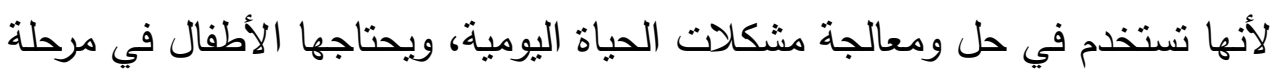
الطفولة المبكرة لأنها تتماشى مع متطلبات نموهم المعرفي وتحصيلهم العلمي في هذه المرحلة.

Caballero-García, "وتتفق هذه النتيجة مع نتائج دراسة "كاباليرو -غارسيا"

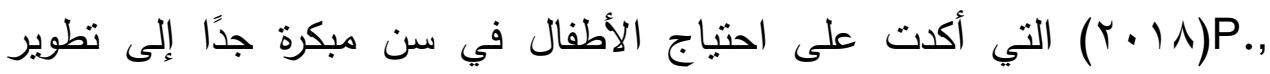
المهارات العلمية وخاصة مهارات الملاحظة باعتبارها كفاءة أساسية في الحياة والمدرسة في عالم دائم التغير •

كما تُرجع الباحثة هذه النتيجة إلى طبيعة البرنامج الذي اعتمد على استراتيجية المحطات العلمية والتي تهتم بخلق بيئة تعليمية مناسبة تتيح للمتعلمين القيام بعملية

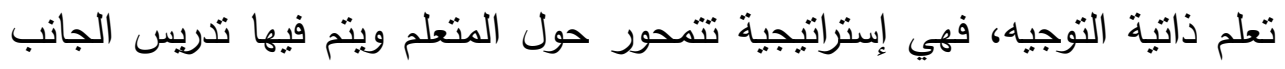
النظري والعملي للمحتوى العلمي، وتدعم تعليم المفاهيم المجردة وكذلك المفاهيم التي تحتاج إلى قدر كبير من التكرار ، ويمكن للمحطات أن تغطي مفهوم واحد أو العديد ولثي

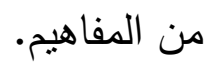

Aydogmus, M., \& وتتقق هذه النتيجة مع نتائج دراسة "ايدوجمس وسينترك" ف Şentürk, C,, فعالية من طرق التدريس التقليدية، فهي تزود المتعلمين بفرص أفضل لممارسة وتطوير معارفهم ومهاراتهم المستهدفة (CARVAJAL, S., 2020, 13). كما تتفق هذه النتيجة مع توصيات العديد من الدراسات والتي أوصت بضراتهم بضرورة توظيف استراتيجية المحطات العلمية فى برامج ومناهج مرحلة الروضة مثل دراسة لونة

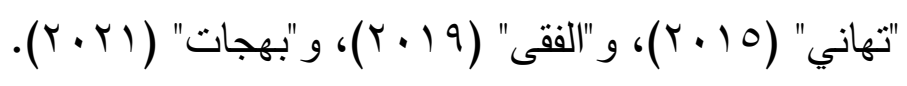

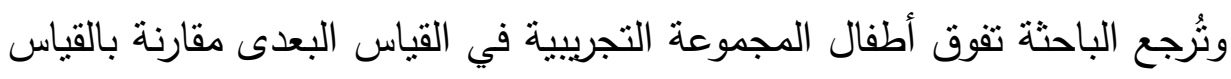

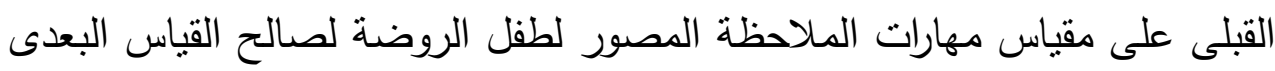

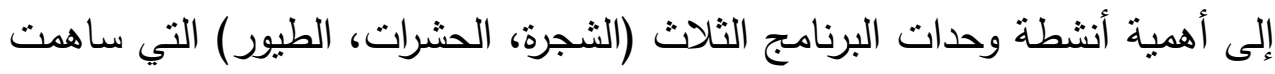

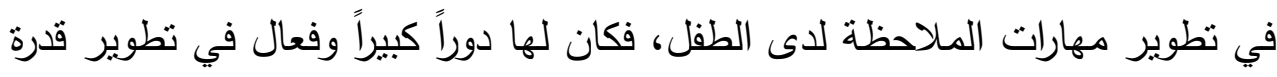
الطفل على تسمية عناصر أو مكونات الموقف التعليمي (الموضوع المراد ملاحظته) 
مجلة بحوث ودراسات الطفولة - كلية التربية للطفولة المبكرة - جامعة الفيوم لـ العدد الخامس عشر

وخصائص هذه المكونات أو العناصر ، وقدرته على إيجاد العلاقات بين عناصر أو

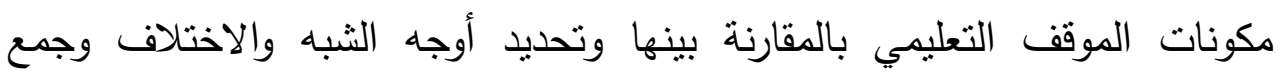
البيانات ذات الصلة، وكذلك قدرته على استخلاص مفاهيم وقيم وأفكار جديدة وربطها بخبراته السابقة في ضوء الحقائق المعطاة له حول عناصر أو مكونات الموقف التعليمي.

Kongpa, M., et وتتفق هذه النتيجة مع ما قدمته دراسة "كونغبا وآخرون

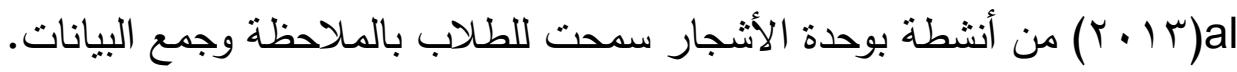

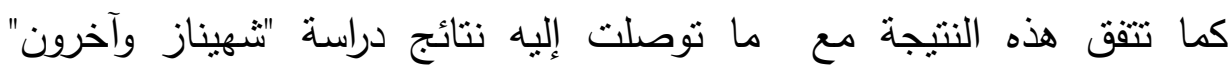
Sahnaz, S., et al, لصقل مهاراتهم في الملاحظة تكون قادرة على استيعاب الطلاب للملاحظة بنشاط وتركيز

وثُرجع الباحثة نسب التحسن في مهارات البرنامج: الوصف، التفسير والتي حصلتا على الترتيب الأول، ثم مهارة الاستتاج والتي حصلت على الترنيب الثانى إلى طبيعة كل مهارة وأنشطة البرنامج التي استهدقت نطويرها في كل نشاط من الأنشطة.

مهارة الوصف والتي استهدفت تطوير قدرة الطفل على تسمية عناصر أو مكونات الموقف التعليمي (الموضوع المراد ملاحظته) وخصائص هذه المكونات أو العناصر

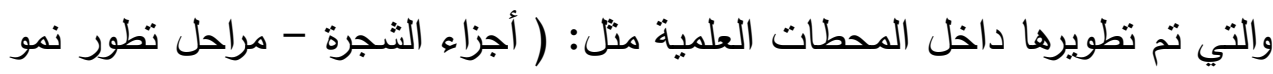
الثجرة- احتياجات الثجرة- طرق تكاثز الأشجار - أنواع الأشجار - أوجه إستفادة

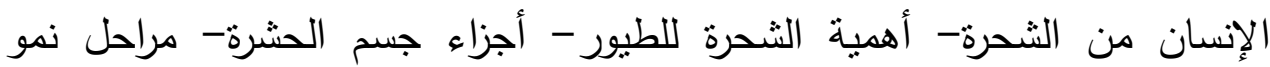
الحشرات- طرق تتقل الحشرات- أمثلة لغذاء الحشرات- أمثلة للحشرات النافعة والضارة للإنسان - أمثلة للحشرات النافعة والضارة للنبات ...إلخ ). فمهارة الوصف تعني بتتمية قدرة المتعلم على تحليل الثكل بدلالة مكوناته

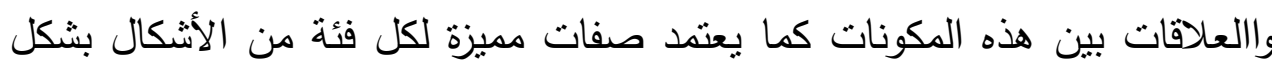
تجريبي، كما أنه يقارن بين الأثكال بالاعتماد على الخصائص وليس الشكل العام

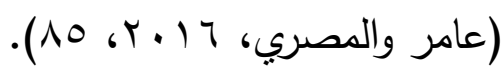


مهارة التفسير والتي تعني بتطوير قدرة الطفل على إيجاد العلاقات بين عناصر

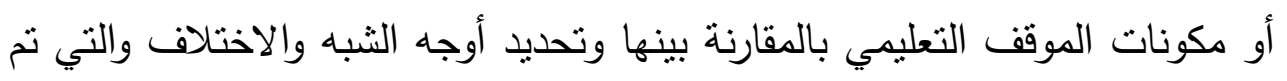
تطويرها داخل المحطات العلمية منل: ( أجزاء الثجرة وأجزاء جسم الإنسانخصائص كل جزء من أجزاء الثجرة ووظيفته- مسمى كل مرحلة من مراحل تطور

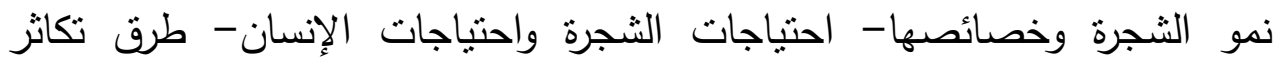

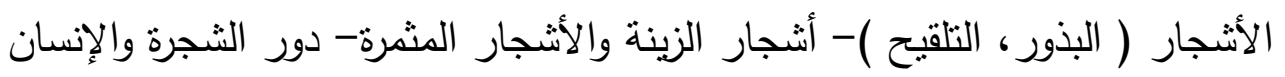

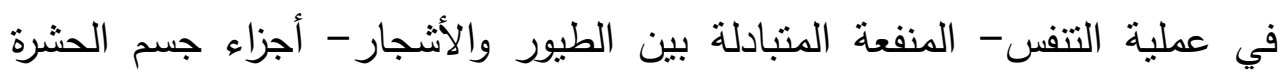
وأجزاء جسم الإنسان - خصائص شكل الفراشة في كل مرحلة- الحشرات من حيث غذائها - منافع وأضرار الحشرات للإنسان - منافع وأضرار الحشرات للنبات ... إلخ). فمهارة التفسير هي عملية عقلية غرضها تفسير الموضوع أو الحدث أو الثئ موضوع الملاحظة والتفكير، وهو عبارة عن استخلاص المعنى أو القانون المنظم

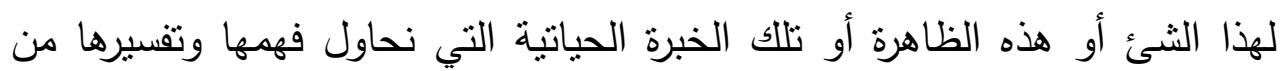

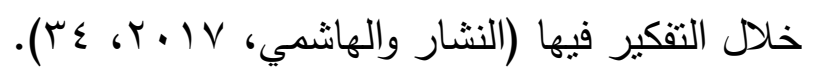
مهارة الاستنتاج والتي تعني بتطوير قدرة الطفل على استخلاص مفاهيم وقيم

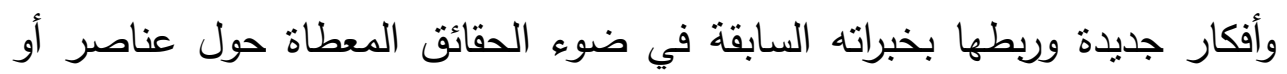
مكونات الموقف التعليمي والتي تم تطويرها داخل المحطات العلمية منها: (التشابه في خلق الكائنات الحية- الله الخالق سبحانه وتعالى - ميز كل جزء من أجزاء الشجرة بخصائص معبنة ليقوم بوظيفته- الثجرة تمتلك دورة حياة كغيرها من الكائنات الحية- توفير الاحتياجات الأساسية للشجرة من طرق العناية بها- تكاثر

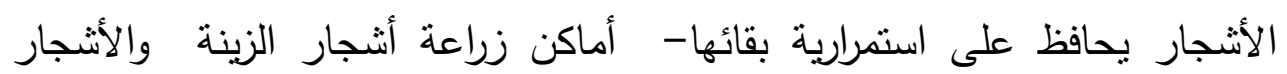

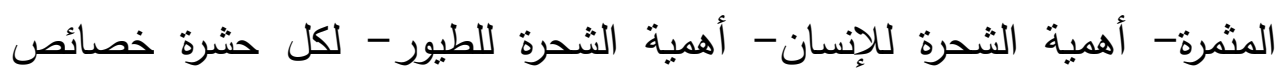

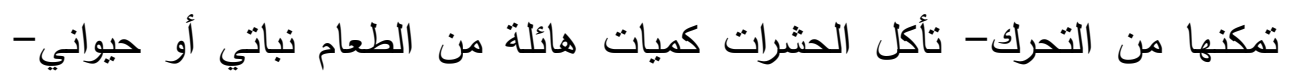
الفائدة من خلق الحشرات للإنسان - الفائدة من خلق الحشرات للنبات .. إلخ ).

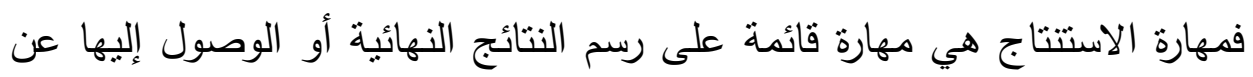

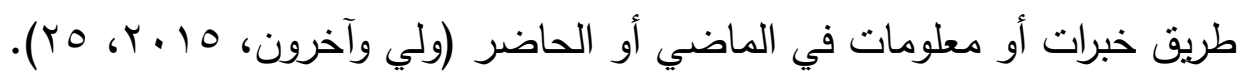


مجلة بحوث ودراسات الطفولة ـ كلية التربية للطفولة المبكرة - جامعة الفيوم لـ العدد الخامس عشر

الفرض الثالث:

يوجد فرق دال إحصائيًا بين متوسطي درجات أطفال المجموعة التجريبية في القياسين البعدي وإلتبعي على مقياس مهارات الملاحظة المصور لطقل الروضة لصالح القياس التتبعي. وللتحقق من صحة هذا الفرض تم استخدام اختبار "T-Test" للعينات المرتبطة، ويوضح جدول (r ا ) التالي نتائج ذلك: هدرئ جلول (1)

نتائج اختبار "T-Test" لالالة الفرق بين متوسطي درجات أطفال المجموعة التجريبية في القياسين البعدي والتتبعي على مقياس مهارات الملاحظة المصور لطفل الروضة ن=rrr

\begin{tabular}{|c|c|c|c|c|c|c|c|c|}
\hline \multirow{2}{*}{ مستوى } & \multirow{2}{*}{ قالمحسوية } & \multirow{2}{*}{ اللانحراف } & \multirow{2}{*}{ متوسط } & \multicolumn{2}{|c|}{ المجموعة التجريبية } & \multicolumn{2}{|c|}{ المجموعة التجريبية } & \multirow{2}{*}{ أبعاد } \\
\hline & & & & الانصراف & الحستوسط & الانحراف المعياري & الحسابي & \\
\hline مستوى &..$v v$. &. .419 & $\cdot 1$ & . & $1 \leq .17$ & 1.1. & $1 \leq . .7$ & البعد الأول \\
\hline مسنوى & $\cdots$ & $\cdot . \cdot \cdot r$ & $\ldots$ & 1.17 & $17.9 \leqslant$ & 1.1. & $17.9 \xi$ & الثانى \\
\hline دالة عن & 19.90 & 1.9. & .10 & $.9 \leqslant 5$ & $1 \Gamma . \wedge \Lambda$ & 1.11 & IT.VY & البعد \\
\hline
\end{tabular}




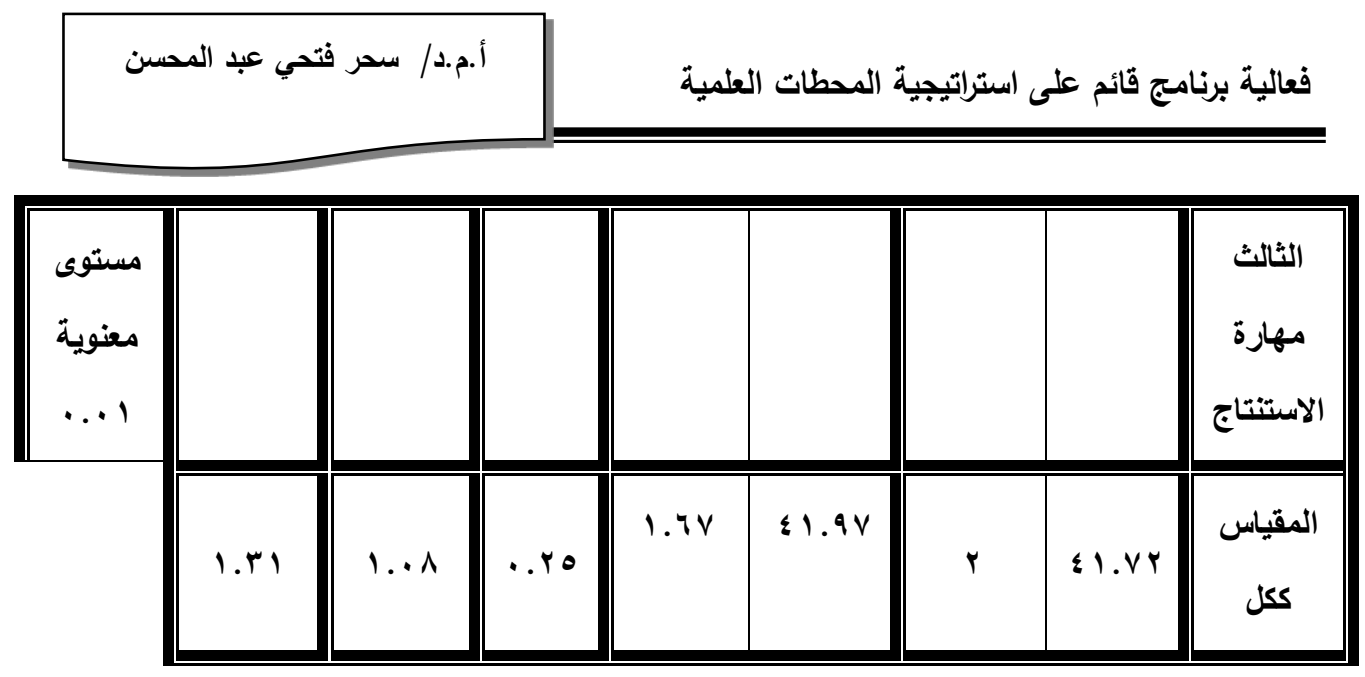

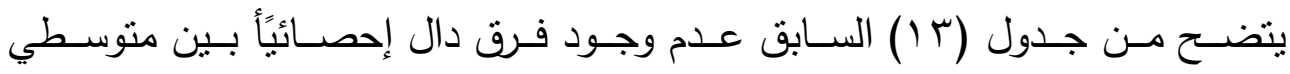

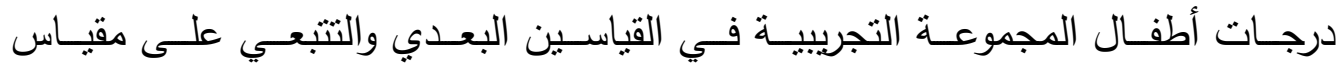

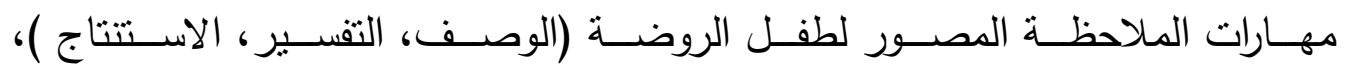

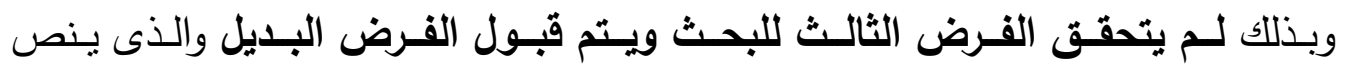

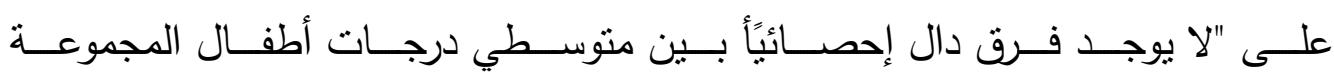

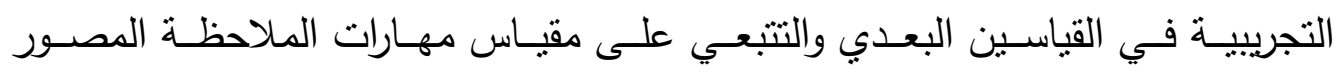

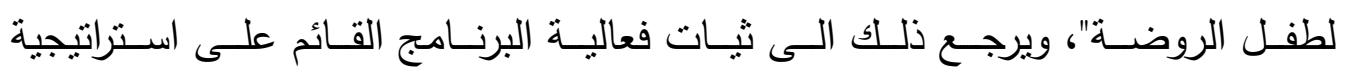
المحطات العلمية في تطوير مهارات الملاحظة لدى طفل الروضة.

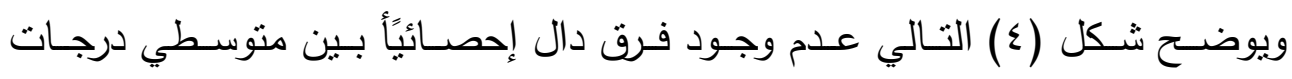

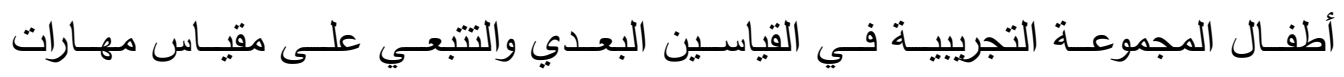
الملاحظة المصور لطفل الروضة: 
مجلة بحوث ودراسات الطفولة _ كلية التربية للطفولة المبكرة - جامعة الفيوم ل العدد الخامس عشر

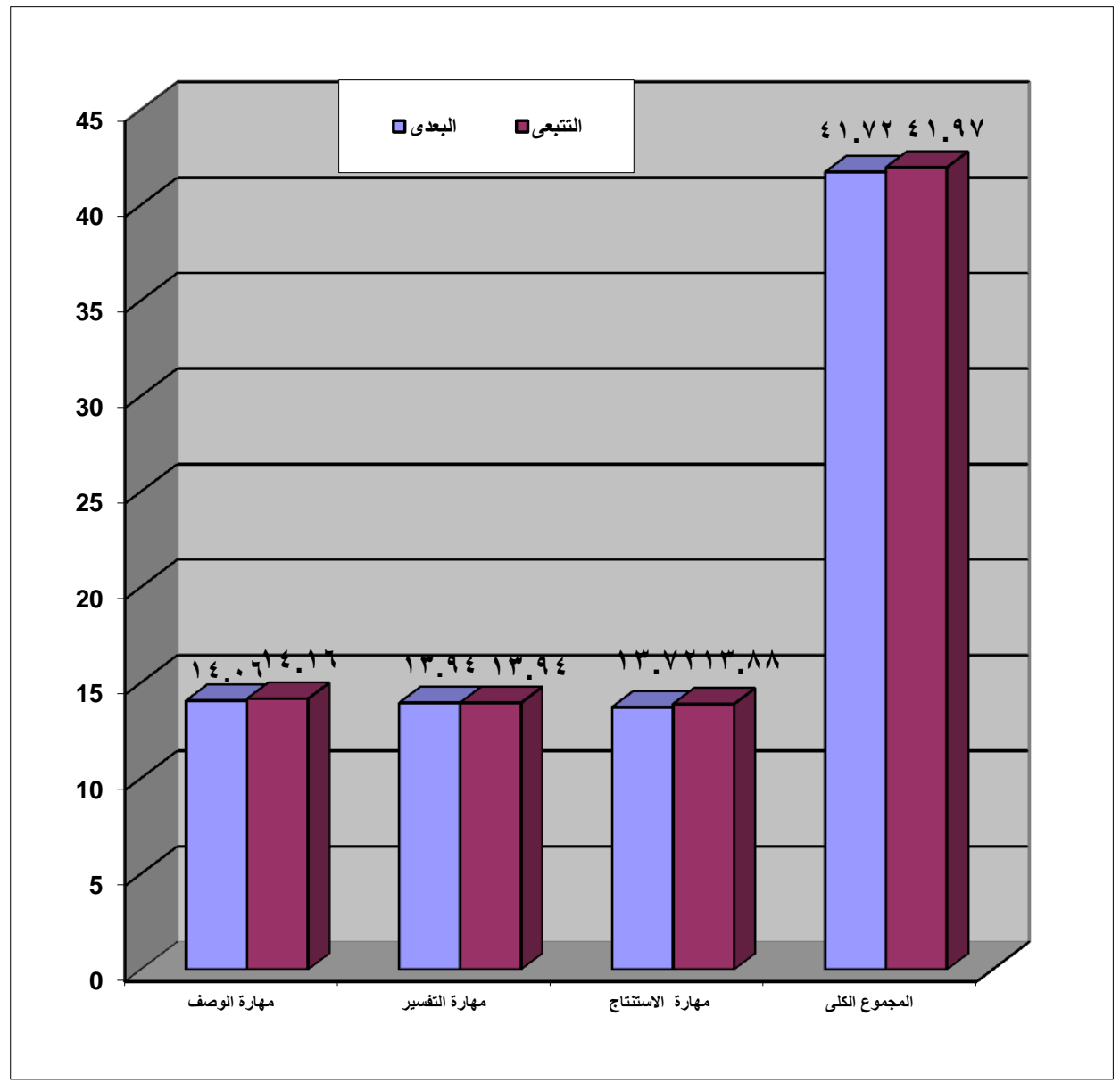

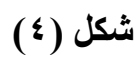

عدم وجود فرق دال إحصائيًا بين متوسطي درجات أطفال المجموعة التجريبية في القياسين البعدي والتتبعي على مقياس مهارات الملاحظة المصور

\section{تفسير ومناقثة نتائج الفرض الثالث :}

وثُرجع الباحثة هذه النتيجة إلى ثيات فعالية البرنامج الذي اعتمد على استراتيجية المحطات العلمية فهي من استراتيجيات التعلم الاجتماعي والتي نتيح للمتعلمين القيام بعملية تعلم ذاتية التوجيه تتمحور حول المتعلم. 


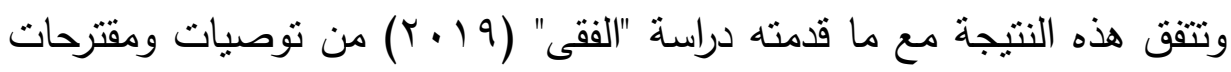
في ضوء نتائج البحث التي توصلت إليها من أبرزها ضرورة توظيف استراتيجية

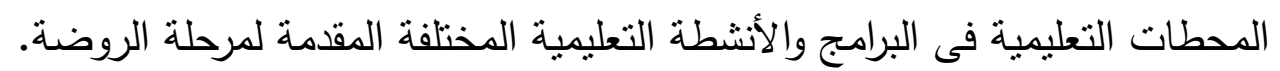

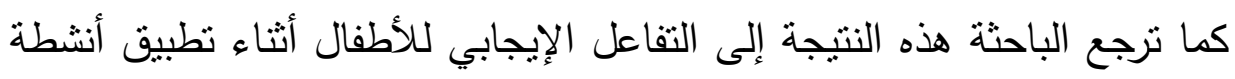

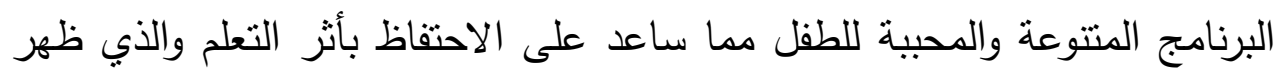

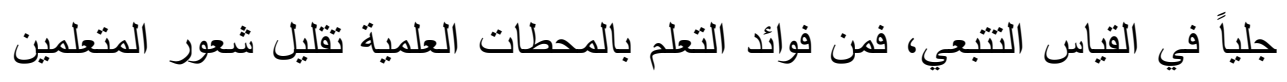

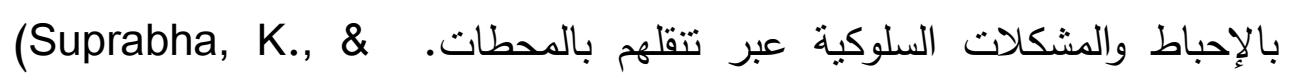
Subramonian, G., 2014, 24) كذللك يمكن إرجاع هذه النتيجة إلى توافر البيئة العاطفية أثناء تطبيق البرنامج

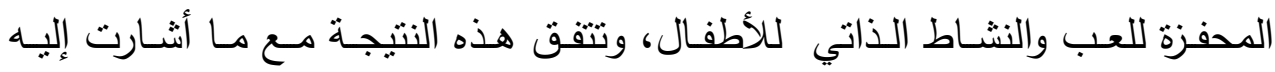

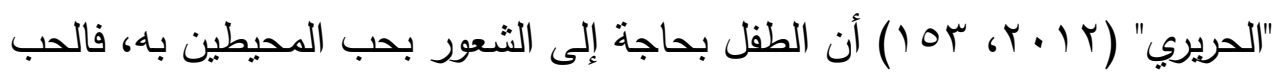

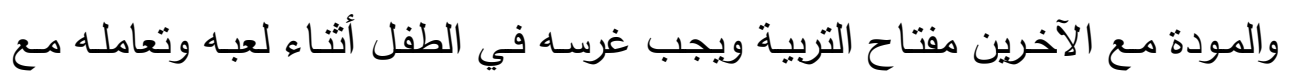
الآخرين. ويذلك قـ تم الإجابة على سؤال البحث الثالث الأي نص على : ما فعالبة البرنامجج القائم على استراتيحية المحطات العلمية في تطوير مهارات الملاحظة لدى طقل الروضة ؟ ويالتالي قات تحقق الهرف الثالث للبحث وهو : قياس فعالبة البرنامج القائم على استراتيحية المحطات العلمية في تطوير مهارات الملاحظة لدى طقل الروضة.

\section{توصسـيات البحــث}

1. إعداد بيئة مناسبة في رياض الأطفال لنطوير مهارات الملاحظة لدى الطفل.

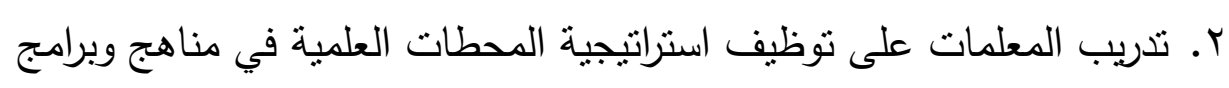
رياض الأطفال.

r. إعداد دليل للمعلمة يتتاول أنشطة البرنامج القائم على استراتيجية المحطات العلمية لتطوير مهارات الملاحظة لدى طفل الروضة. ع. رفع وعي العاملين في مرحلة الطفولة المبكرة بأهمية كون الطفل هو محور عملية التعلم. 
مجلة بحوث ودراسات الطفولة - كلية التربية للطفولة المبكرة - جامعة الفيوح بـ العدد الخامس عثر

ه. رفع وعي العاملين في مرحلة الطفولة المبكرة بأهمية نوظيف التكنولوجيا في توني تعليم وتعلم الطفل.

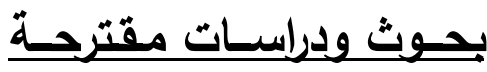

ا ـ فعالية استراتيجية المحطات العلمية في تتمية مهارات التعلم الذاتي لاى طفل الروضة.

r. توظيف استراتيجية المحطات العلمية في تتمية مهارات التفكير الناقد لدى أطفال الروضة.

r. فعالية برنامج قائم على استراتيجية المحطات العلمية في تعزيز التحصيل

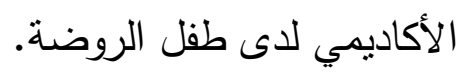
ـ. فعالية استراتيجية الزيارات الميدانية في تطوير مهارات الملاحظة بمرحلة الطفولة المبكرة.

0. برنامج قائم على الأنشطة المصاحبة للأفلام التعليمية لتطوير مهارات الملاحظة لاى طفل الروضة.

T. برنامج قائم على الفيديوهات التعليمية لتطوير مهارات الملاحظة لدى طفل الحضانة.

V. فعالية قراءة الصورة الرقمية في تطوير مهارات الملاحظة لدي الأطفال الصغار.

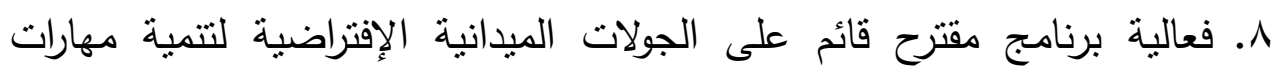
الملاحظة لاي الأطفال الصغار . 


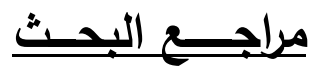

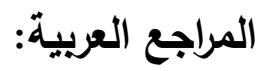

ا. إبراهيم، يارا إبراهيم محمد (·r • (Y). إستخدام استراتيجية المحطات التعليمية التفاعلية في تتمية المفاهيم والسلوكيات البيئية والحس الجمالي لدى لدى طفل الروضة. مجلة دراسات في الطقولة والتريية. جامعة أسيوط: كلية التربية

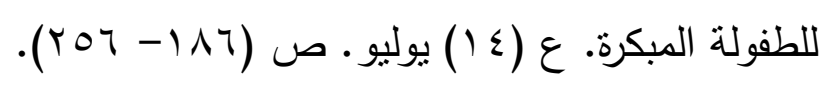

Y. أحمد، ابتسام سلطان عبدالحميد (9 (1). أثر استراتيجيتي محطات التعلم والخرائط الذهنية في تتمية بعض مفاهيم الثقافة الصحية لدى طفل الروضة.

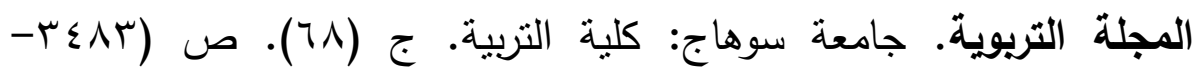

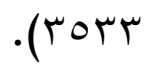

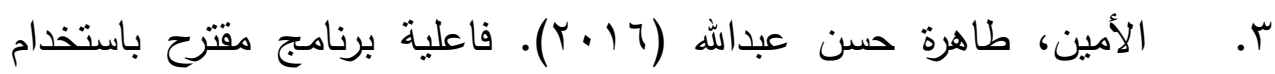

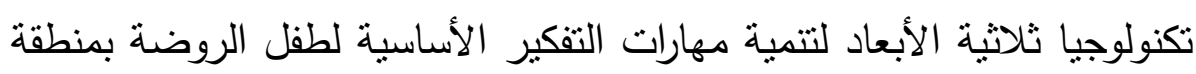

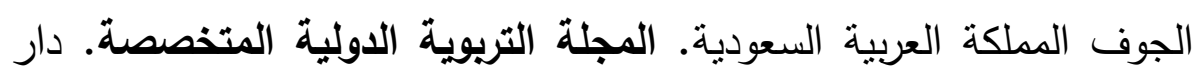

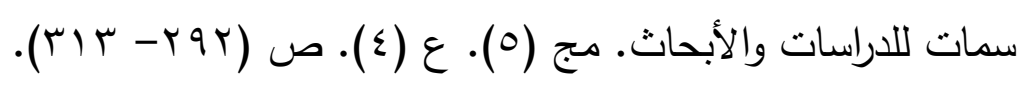

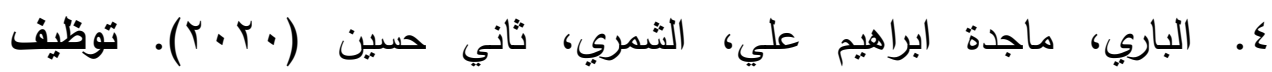
استراتيجيات التعلم النشط في اكتساب عمليات العلم. لبنان: دار الكتب العلمية.

0. بهات، ريم محمد بهيج فريد (Y) (Y). فاعلية برنامج قائم على استخدام المحطات التعليمية في تتمية مفاهيم الفضاء وعلوم الأرض لدى طفل الروضة. مجلة بحوث ودراسات الطقولة. جامعة بني سويف: كلية التربية للطفولة

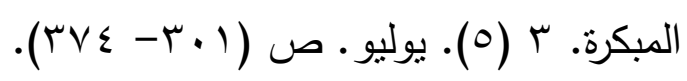

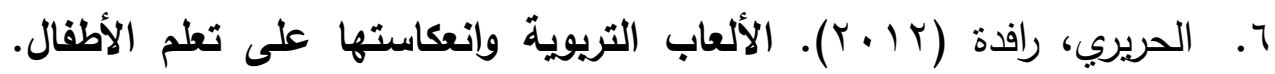

الأردن. عمان: اليازوري.

V. حسن، أماني عبدالمنعم محمد (9 (19). تقويم محتوى منهج "اكتشف، تعلم

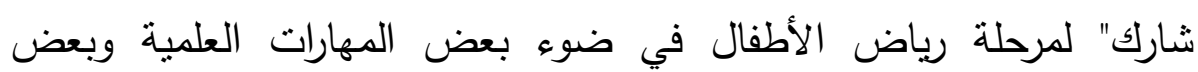


مجلة بحوث ودراسات الطفولة - كلية التربية للطفولة المبكرة - جامعة الفيوم لـ العدد الخامس عشر

مهارات علم النفس الإيجابي من وجهة نظر معلمات الروضة. مجلة دراسات في الطقولة والتربية. جامعة أسيوط - كلية التربية للطفولة المبكرة. ع (1) (1).

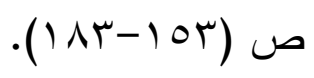

^. سليمان، تهاني محمد (10 (Y). برنامج أنشطة مقترح قائم على المحطات العلمية لإكساب أطفال الروضة بعض المفاهيم العلمية وعمليات العلم. المجلة

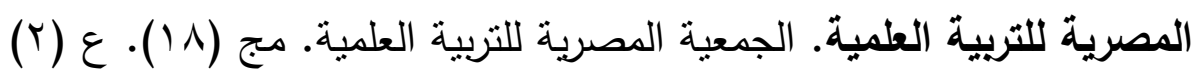

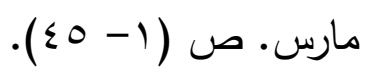

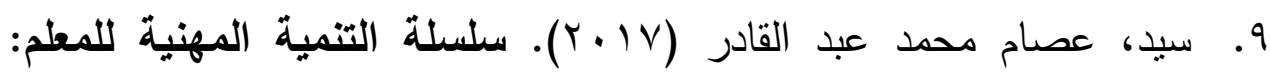
نماذج وإستراتيجيات التدريس الفعال: الحقيبة التدريبية الحادية عشر. الإسكندرية: دار التعليم الجامعي.

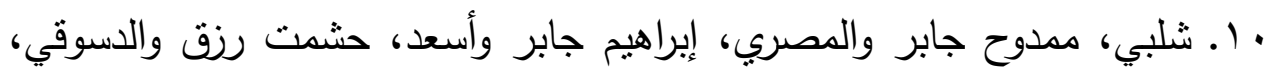

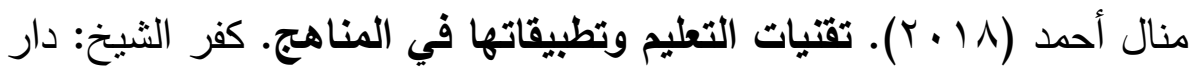

$$
\text { العلم والإيمان للنشر والتوزيع. }
$$

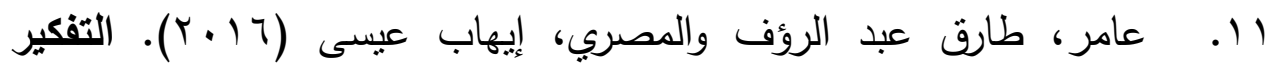

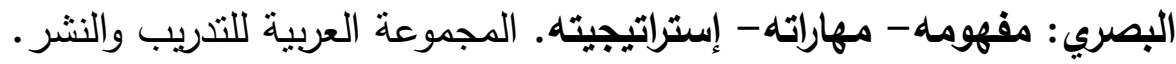

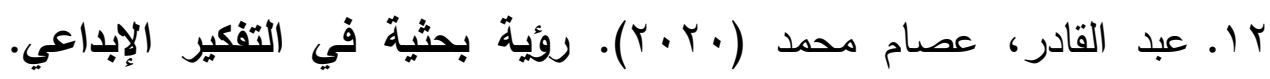
الإسكندرية: دار التعليم الجامعي.

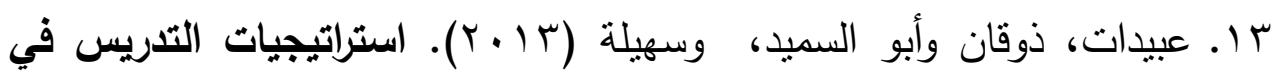

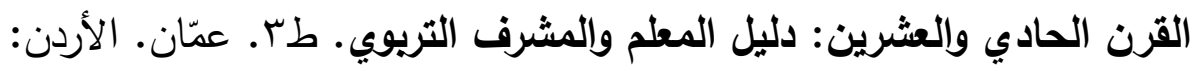
دييونو للطباعة والنشر والتوزيع.

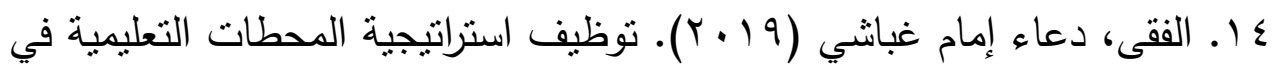
تتمية المفاهيم الوقائية البيولوجية لمرحلة الروضة. دهلة مجلة الطقولة والتربية.

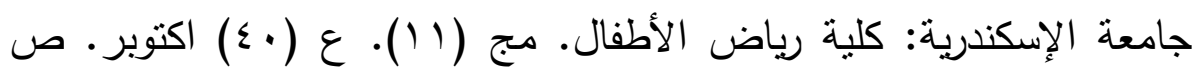

$$
\text { . (r. - (rTq) }
$$

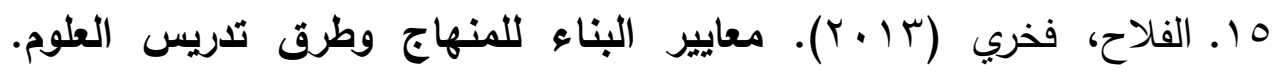
الأردن. عمان: دار بافا العلمية للنشر والتزيع. 
7 ( . منصور ، سحر سامى صلاح (Y.Y.Y). فاعلية برنامج قائم على المحطات التعليمية في الحد من الآثار السلبية لتعرض طفل الروضة لمفردات العالم الافتراضي. مجلة كلية رياض الأطفال. جامعة بورسعيد: كلية رياض الأطفال.

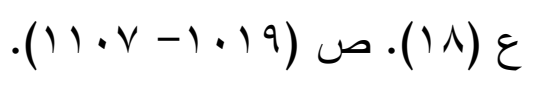

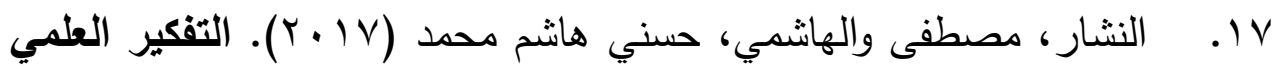

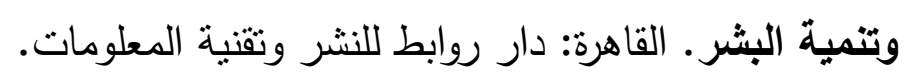

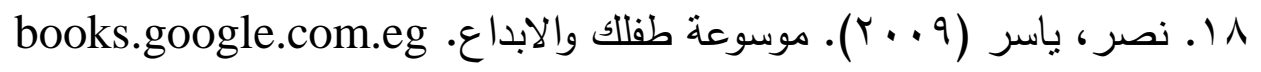

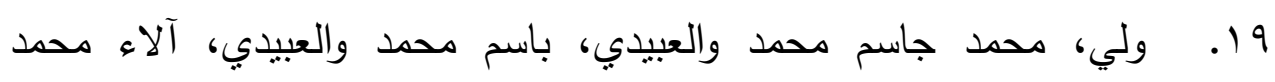

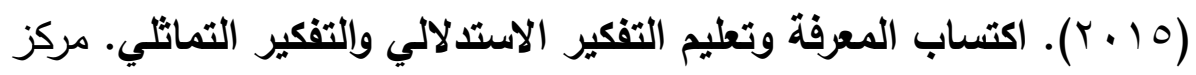
ديبونو لتعليم التفكير •

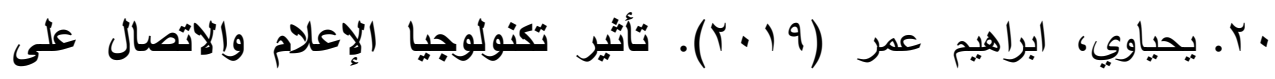

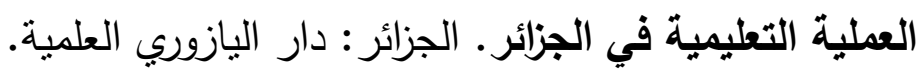

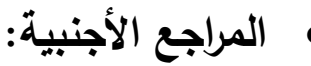

1. Aqel, M. S \& Haboush, S. M (2017): The Impact of Learning Stations Strategy on Developing Technology Concepts among Sixth Grade Female Students, International Journal of Academic Research in Progressive Education and Development, V., (6), N., ISSN: 2226-6348.

2. Aydogmus, M., \& Sentürk, C., (2019): The effects of learning stations technique on academic achievement: A meta-analytic study, Research in Pedagogy, V., (9), N., (1), P., (1-15).

3. Caballero-García, P., (2018): Inquiry-based learning: an innovative proposal for early childhood education, 
مجلة بحوث ودراسات الطقولة _ كلية التربية للطفولة المبكرة - جامعة الفيوم ] [ العدد الخامس عشر

Journal of Learning Styles, V., (11), N., (22), P $(50-82)$.

4. CARVAJAL, S., (2020): Language Learning Stations: Influencing Learners' Autonomy in the EFL Classroom, MASTER'S REPORT, UNIVERSIDAD ICESI.

5. Fauzi, F., Wangid, M., Prasetyo, Z., (2019): Observational Skill: The Use of Picture Storybook with Scientific Approach Based Through ProjectBased, Learning, International Conference on Learning Innovation and Quality Education (ICLIQE 2019) Social Science, Education and Humanities Research, V., (397), P (701-708).

6. Fulbeck, E., Atchison, D., Giffin, J., Seidel, D., Eccleston, M., (2020): Personalizing Student Learning With Station Rotation: A Descriptive Study, Overdeck Family Foundation, American Institutes for Research.

7. Harlen, W., (2014): Helping children's development of inquiry skills, Inquiry in primary science education (IPSE) 1: p. (5-19).

8. Johnston, J., (2009): What does the skill of observation look like in young children? Int J Sci Educ, 31 (18), P (2511-2525), Paper presented at the British Educational Research Association 
Annual Conference, Heriot-Watt University, Edinburgh, 3-6 September 2008.

9. Jones, D., (2007): The Station Approach: How to Teach With Limited Resources. National Science Teachers Association, 16- 21.

10. Kohlhauf, L., Rutke, U., Neuhaus, B., (2011): Influence of Previous Knowledge, Language Skills and Domain-specific Interest on Observation Competency, Springer Science+Business Media, LLC 2011, J Sci Educ Technol (2011) 20, P (667678).

11. Kongpa, M., Jantaburoma, P., Bynea, D., Obmasuya, N., Yuenyongb, C., (2013): Kindergarten's Scientific Concepts and Skills in the Tree Unit, Procedia Social and Behavioral Sciences, 116 (2014), 2120 - 2124, 5th World Conference on Educational Sciences - WCES 2013.

12. Rahman, M. M., (2019): 21st Century Skill "Problem Solving": Defining the Concept, Asian Journal of Interdisciplinary Research, V., (2), Issue (1), Asian J. Interdiscip. Res., P (71-81).

13. Sahnaz, S., Harlita, Ramli, M., (2018): Improving Observing Skills of High School Students through Guided Inquiry Model, International Journal of Pedagogy and Teacher Education (IJPTE), V., (2), Issue (1), April, P (245 -258). 
مجلة بحوث ودراسات الطفولة ـ كلية التربية للطفولة المبكرة - جامعة الفيوم ] العدد الخامس عشر

14. Suprabha, K., Subramonian, G., (2014): HOW DOES STATION TEACHING EFFECT LANGUAGE LEARNING, i-manager's Journal on English Language Teaching, V., (4I), N., (3I), JulySeptember. $P(21-25)$.

15. Yurumezoglu, K., \& Oztas Cin, M., (2019): Developing Children's Observation Skills Using a Fractal Pattern from Nature, Science Activities: Projects and Curriculum Ideas in STEM Classrooms, V., (56), N., (2), P (63-73). 